Portland State University

PDXScholar

1990

\title{
Exurban Commuting Patterns: A Case Study of the Portland Oregon Region
}

Judy Seppanen Davis

Portland State University

Follow this and additional works at: https://pdxscholar.library.pdx.edu/open_access_etds Let us know how access to this document benefits you.

\section{Recommended Citation}

Davis, Judy Seppanen, "Exurban Commuting Patterns: A Case Study of the Portland Oregon Region" (1990). Dissertations and Theses. Paper 1212.

https://doi.org/10.15760/etd.1211

This Dissertation is brought to you for free and open access. It has been accepted for inclusion in Dissertations and Theses by an authorized administrator of PDXScholar. Please contact us if we can make this document more accessible: pdxscholar@pdx.edu. 
EXURBAN COMMUTING PATTERNS

A CASE STUDY OF THE PORTLAND OREGON REGION

\author{
by \\ JUDY SEPPANEN DAVIS
}
A thesis submitted in partial fulfillment of the requirements for the degree of
DOCTOR OF PHILOSOPHY
of
URBAN STUDIES

Portland State University

01990 
TO THE OFFICE OF GRADUATE STUDIES:

The members of the Committee approve the dissertation of Judy Seppanen Davis presented January 22, 1990.

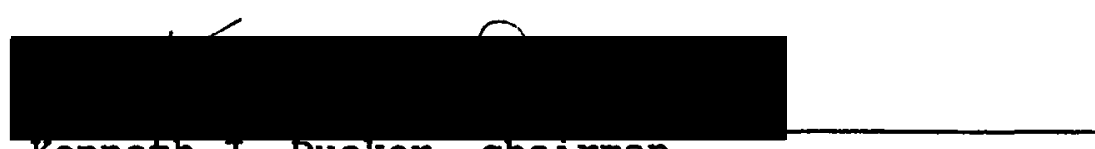

Kenneth J. Dueker, chairman

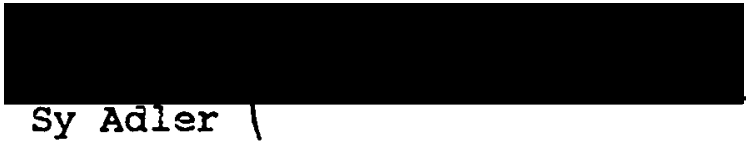

Sy Adler

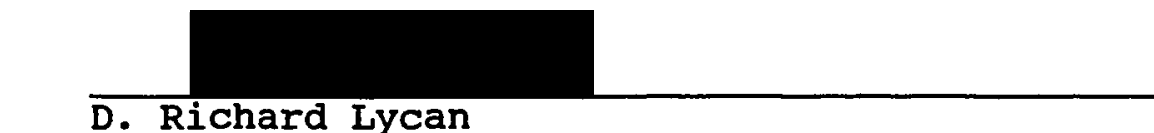

D. Richard Lycan

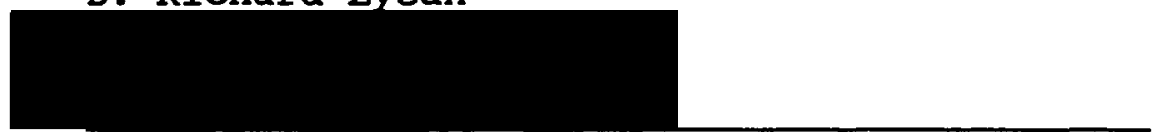

James Strathman

Kent Lall

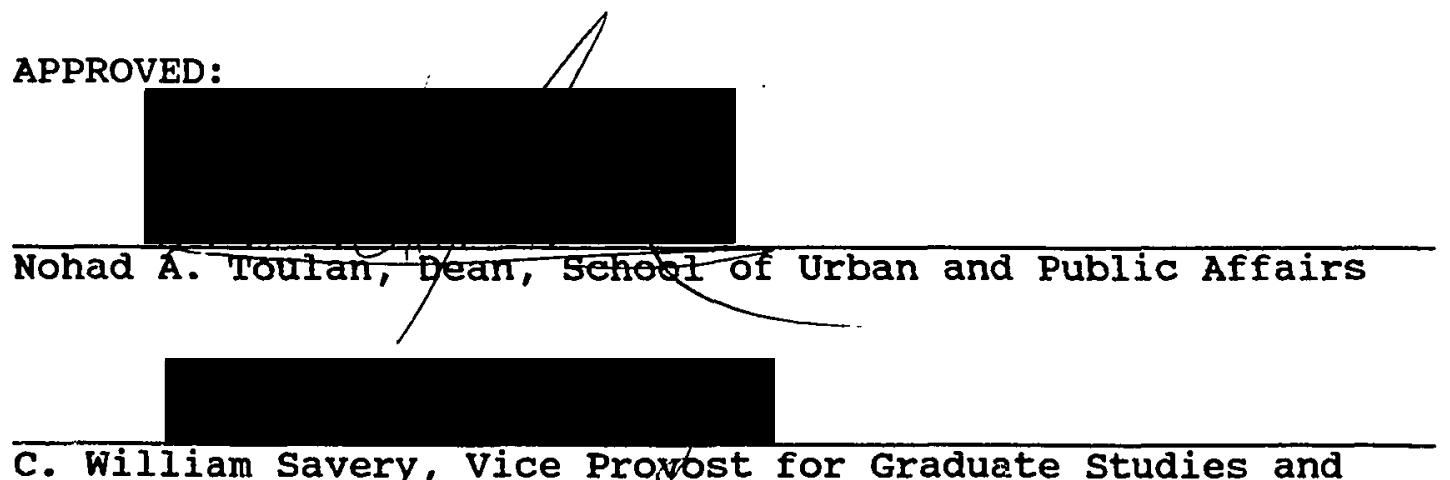
Research 
AN ABSTRACT OF THE DISSERTATION OF Judy Seppanen Davis for the Doctor of Philosophy in Urban Studies presented January 22,1990

Title: Exurban Commuting Patterns: A Case study of the Portland Oregon Region

APPROVED BY MEMBERS OF THE DISSERTATION COMMITTEE:

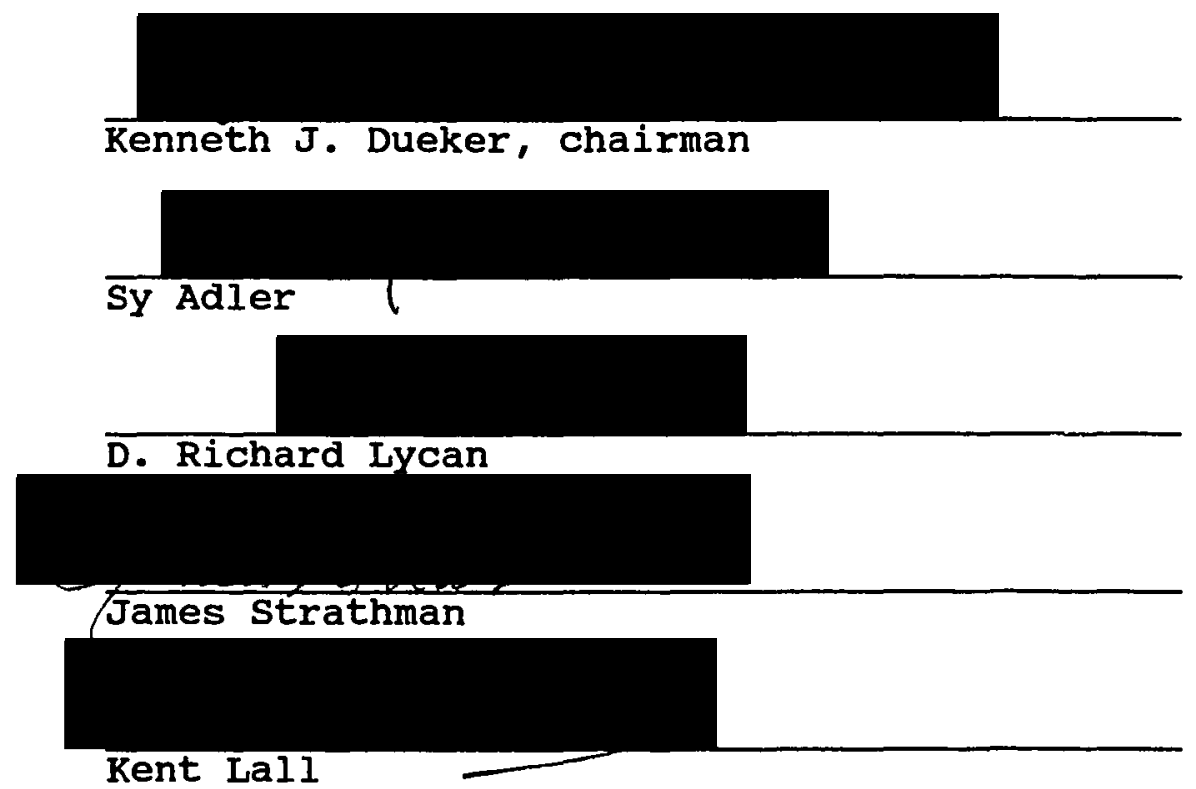

Many North Americans have been moving to exurbia--low density, rural housing within the commuting range of urban areas. It has been assumed that employment is a major link. of exurban households with urban areas. This analysis of exurban commuting patterns is based on a mail survey of 1408 households who bought homes in 1987 near Portland, oregon. 
The bid-rent model of urban form predicts that exurbanites will trade-off long commutes for lower housing prices. But previous research suggests that exurban living may not require long commutes because of decentralized employment.

The study finds that exurban commuters travel farther than suburban commuters and pay less for housing. Exurban home buyers do not, however, have longer commutes the farther out they live. Instead those with urban jobs generally locate closer to the city center than those with decentralized jobs.

The commuting times of exurban principal wage earners are also influenced by occupation, flextime use, and by the presence and employment status of other adults in the household. The commuting times of exurban secondary wage earners are influenced by the number of hours they work, their mode of travel, and the number of children they have.

Although most exurban home buyers moved to obtain a bigger lot and a more rural environment, there were many differences among households. Four types of exurban households were identified with cluster analysis. Only the Child-Raising households take full advantage of decentralized jobs to live in rural areas without longer commutes than suburbanites. In contrast, Long-DistanceCommuters travel nearly twice the average time because they usually hold urban jobs and want large, but inexpensive, 
lots. Affluents also hold many urban jobs but can afford larger lots closer-in than others. The Economy-Minded commute average distances to obtain cheaper housing on smaller lots.

This study improves understanding of the exurban development process. The study also finds that the bid-rent model of urban form is a useful theory for understanding exurban development despite the decentralization of employment and the predominance of two wage earner households. 


\section{ACKNOWLEDGEMENTS}

This research was supported by a grant from the United States Department of Transportation. Thanks to Dr. Dueker for arranging the funding and guiding the research, the other members of the committee for their assistance, Dr. Arthur C. "Chris" Nelson of the Georgia Institute of Technology for helpful advise on surveys and review of several chapters, the staff of the Center for Urban studies for help with the administration of the survey, my husband for loving support, and our children for patiently enduring both parents' dissertations. 
TABLE OF CONTENTS

PAGE

ACKNOWLEDGEMENTS - . . . . . . . . . . . . . . . iii

LIST OF TABLES • . . . . . . . . . . • . . . . . vii

LIST OF FIGURES . . . . . . . . . . . . . . . . . . xi

CHAPTER

I INTRODUCTION . . . . . . . . . . . . . 1

II REVIEW OF THE LITERATURE . . . . . . . . . 5

Exurban Residential Development . . . . 5

Urban Form Theories . . . . . . 6

Demand for Public Goods and Services 12

Suburban and Rural Residential Growth 13

Summary . . . . . . . . . . 16

Metropolitan and Exurban Commuting Patterns 17

Metropolitan Commuting Research . . 17

Exurban Commuting Research . . . . 26

Conclusions . . . . . . . . . . . 28

III RESEARCH METHODS . . . . . . . . . . . 31

Study Area . . . . . . . . . . . . 35

Sampling . . . . . . . . . . . . 37

Data Collection . . . . . . . . . 41

Primary Data . . . . . . . . . 41

Secondary Data... . . . . . . 49

Data Analysis . . . . . . . . . . 50

Research Hypotheses . . . . . . . . 51 
DESCRIPTIVE RESULTS . . . . . . . . . 53

Who are the Exurban Home Purchasers? . . 54

Former Residence . . . . . . . 55

Workforce Participation . . . . . 57

Noncommuters . . . . . . . . . . 58

Job Location . . . . . . . . . 60

Occupation and Income . . . . . 62

Summary . . . . . . . . . . . . 64

Why Did They Move? . . . . . . . . 66

Motivations for Moving . . . . . 67

Lot sizes . . . . . . . . . . 70

Summary . . . . . . . . . . . . 71

How Did Moving Affect Commuting? . . . 72

Commuting Trip Characteristics . . . 72

Changes in Commuting Trips . . . . 81

Summary . . . . . . . . . . . 86

Exurban Household Types . . . . . . . 87

Cluster Analysis Results . . . . . 89

Other Characteristics of Clusters . 93

Summary . . . . . . . . . . 100

Conclusions . . . . . . . . . . 102

V ANALYTICAL RESULTS . . . . . . . . • . 107

Estimation of Commuting Time . . . . . 108

General Results . . . . . . . . 114

Results for Residential Location

Variables . . . . . . . . . 115

Results for Family Variables . . . 119

Results for Individual Variables . . 121

Results for Job Variables . . . . 122

Summary . . . . . . . . . . 126

Estimation of Housing Price . . . . . 127

General Results . . . . . . . 130

Results for Housing and Public

Services/Costs Variables . . . 130

Results for Residential Location

Variables . . . . . . . . . 132 


$$
\begin{aligned}
& \text { Summary • • . • . • . . . • . } 135 \\
& \text { Conclusions . . . . . . . . . . } 135 \\
& \text { VI DISCUSSION AND CONCLUSIONS . . . . . . . } 138 \\
& \text { Generalizability of Study . . . . . . } 139 \\
& \text { Theoretical Implications . . . . . } 140 \\
& \text { Exurban Development . . . . . . } 140 \\
& \text { Theory of Urban Form . . . . . . . } 144 \\
& \text { Planning and Policy Implications . . . } 146 \\
& \text { Transportation Planning and Policy . } 146 \\
& \text { Land Use Planning and Policy . . . } 147 \\
& \text { Research Needs . . . . . . . . } 150 \\
& \text { Exurban Development . . . . . . } 150 \\
& \text { Commuting Behavior . . . . . . } 151 \\
& \text { Conclusions . . . . . . . . . . } 153
\end{aligned}
$$

REFERENCES • . . . . . . . . . . . . . . . . 154 APPENDICES
A SURVEY INSTRUMENT AND COVER LETTERS . • • • 161
B TREATMENT OF MISSING DATA . . . . . . . 178
C SUMMARY STATISTICS FOR REGRESSION VARIABLES 180
D ESTIMATING THE EFFECTS OF PROPERTY TAXES AND SCHOOL EXPENDITURES ON HOUSING VALUES . . . 184 


\section{LIST OF TABLES}

I Incorporated Small Towns within the Exurban Study Area with 1987 Population Estimates 38

II Sample Sizes . . . . . . . . . . . . 40

III Mailing Schedule for surveys . . . . . . . . 42

IV Completed Surveys Returned Each Week . . . . 44

V Adjusted Sample Sizes . . . . . . . . . 46

VI Final Rates of Return by Subareas . . . . . 47

VII Purchase Price of Homes of Respondents and Non-Respondents by Subareas . . . . . . 49

VIII Place of Former Residence of Home Purchasers by Residential Subareas . . . . . . . 55

IX Home Purchasers' Descriptions of Present and Former Neighborhoods by Types of Move and Residential Subareas . . . . . . . 56

$\mathrm{X}$ Workforce Participation of Home Purchasers by Residential Subareas . . . . . . . 57

XI Family Characteristics of Households in Workforce by Residential Subareas . . . 58

XII Effect of Move on Commuter's Job Location by Type of Earner and Residential Subareas . 60 
XIII Work Locations of Commuters by Type of Earner and Residential Subareas . . . . . 61

XIV Occupations of Commuters by Type of Earner and Residential Subareas . . . . . 63

XV Household Income by Occupation of Commuting Principal Wage Earner and Residential Subareas . . . . . . . . . . 65

XVI The Three Most Important Reasons for Moving of Home Purchasers by Residential Subareas . . . . . . . . . . . .

XVII The Three Most Important Reasons for Choosing

a Particular Neighborhood by Residential Subareas . . . . . . . . . . . 69

XVIII Lot Sizes Purchased by Residential Subareas 71 XIX Commuting Times and Distances by Type of Wage Earner and Residential Subareas . • 74 XX Mode of Travel to Work by Type of Wage Earner and Residential Subareas . . . . . 76

XXI Stops Made on way to and from work by Type of Wage Earner and Residential Subareas.

XXII Work Schedules of Commuting Principal Wage Earners by Residential Subareas . . . . 78 XXIII Work Schedules of Commuting secondary Wage Earners by Residential Subareas . . . . 79 
XXIV Comparison of Present and Former Work Trips of Commuting Principal Wage Earners by Residential Subareas . . . . . . . 82

XXV Comparison of Present and Former Work Trips of Commuting Secondary Wage Earners by Residential Subareas . . . . . . . 83

XXVI Commuters' Mean Speeds of Travel by Type of Wage Earner and Residential Subareas . . 85 XXVII Definition of Variables Used in K-Means Cluster Analysis . . . . . . . . . 88

XXVIII Cluster Analysis Results for Exurban Households with Commuting Principal Wage Earners . . . . . . . . . . . . 90

XXIX Place of Former Residence of Exurban Home Purchasers by Household Types . . . . . 94

XXX The Three Kost Important Reasons for Moving of Exurban Home Purchasers by Household Types . . . . . . . . . . . . 95

XXXI The Three rost Important Reasons for selecting

a Particular Exurban Neighborhood by Household Types . . . . . . . . . 96 XXXII Size of Lots Purchased in Exurbia by Household Types . . . . . . . . . . 97 XXXIII Job Locations of Exurban Principal Wage Earners by Household Types . . . . . 100 
XXXIV Difference of Mean Commuting Times Hypothesis Testing by Type of Wage Earner . . . . 103

XXXV Definition of Variables in Commuting Time Estimation . . . . . . . . . . 110

XXXVI Regression Equations of Commuting Time of Principal Wage Earners for Combined Sample, Exurban Sample, and Suburban Sample . . . . . . . . . . . . 111

XXXVII Regression Equations of Commuting Time of Secondary Wage Earners for Combined Sample, Exurban Sample, and Suburban Sample . . . . . . . . . . . . 113

XXXVIII Additional Time Principal Wage Earners in

Various Occupational Groups Commute by Residential Subareas . . . . . . . 125

XXXIX Definition of Variables in Price Estimation 128

XL Regression Equations for Prices of Homes Purchased by Commuting Principal Wage Earners for Combined Sample, Exurban Sample, and Suburban Sample . . . . . 129 


\section{LIST OF FIGURES}

FIGURE

PAGE

1. The Metropolitan Urban Growth Boundary . . . 33

2. The Study Area . . . . . . . . . . . . 36

3. Relative Frequency of Commuting Distances by

Residential Subarea and Type of Wage Earner 73

4. Relative Frequency of change in commuting

Distances by Residential Subarea and Type

of Wage Earner . . . . . . . . . . . . 84

5. Relative Frequency of Commuting Times by Exurban

Household Types and Type of Wage Earner . . 92

6. Distribution of Distances from Portland's

Central Business District of Exurban

Principal Wage Earner's Residences by

Household Types . . . . . . . . . . . . . 99

7. Distribution of Distances from Portland's

Central Business District of Exurban

Principal Wage Earner's Residences by Job

Locations . . . . . . . . . 118

8. Effects of the Urban Growth Boundary (UGB) and

the Distance from the Central Business

District (CBD) on Suburban and Exurban

Housing Prices and Principal Wage Earner's

Commuting Times. . . . . . . . . . . . 134 


\section{CHAPTER I}

\section{INTRODUCTION}

During the 1970's and 1980's many Americans moved to rural residential homes on the fringes of cities. Those who chose to move expected to enjoy large lots, open space, recreational opportunities, and other advantages of rural living while having access to urban areas for jobs, shopping, and cultural events. This low-density development beyond the suburbs is known as exurban development and is expected to continue to attract residents in the coming decades.

Exurban development has been described by a number of authors and is of interest to both urban and rural analysts. There is, however, no standard definition of exurbia (Joseph and smit 1981). This study follows urban field theory as developed by Friedman and Miller (1965) and applied by Berry and Gillard (1977). The rural residential area beyond the suburbs but within the commuting range of the urban/suburban area is called exurbia.

There has been much speculation and disagreement about the forces sustaining exurban development and the impacts of this type of development on individuals and society. Some consider exurban development a classic example of urban sprawl and warn of dire consequences for society (Lamb 
1983). Others view exurban development as part of the revitalization of rural areas and consider it an entirely new and promising phase of development (Herbers 1986; Lessinger 1986). Clearly, additional research is needed to understand this phenomena.

It is generally assumed that a major link of exurbanites with urban and suburban areas is employment. Despite this assumed link, little is actually known about the relationships of exurban households to places of work. There are several possibilities. Exurbanites may endure or even enjoy long commutes (Herbers 1986). They may commute no longer in time or distance than their more urban neighbors due to the suburbanization of employment (Dueker et al. 1983) and ease of travel on less congested highways (zimmer 1985). They may travel to work less often due to flexible work times and places (Clawson 1971) or use of telecommuting (Howland 1982). Finally, exurbanites may work at nearby jobs in exurbia or in small towns.

In his recent analysis of U.S. commuting trends, Pisarski (1987) points out that we tend to think of work trips in outdated images from the 1950's and 1960's. Jobs were once concentrated in the central business district but are now spread out within and even beyond metropolitan areas. Babyboomers and women of all ages have swelled the size of the workforce and hence the number of commuting trips. Services, which have different work schedules than manufacturing, have become the predominant growth sector. 
Today more people commute within the suburbs than either within central cities or from the suburbs to central cities. Commuting out of central cities to the suburbs and commuting across metropolitan boundaries is also increasing. In general commuting has become more spread out both in time and space.

Pisarski (1987) concludes that additional research is needed to better understand today's commuting and its implications for transportation policy and planning. one type of research that he recommends is case studies to provide more detail about commuting trends.

This case study of the Portland, Oregon, region analyzes and compares the emerging commuting patterns of exurban, small town, and suburban households. The analysis is based on a mail survey of 1408 households who purchased homes in 1987. By examining the types of households moving to exurbia, their reasons for moving, and the impacts of their moves on journey-to-work a picture is drawn of the forces shaping exurban development. In particular, the analysis tests whether the bid-rent theory of urban form is a valid tool for understanding exurban development in this period of extensive deconcentration of employment. The implications of exurban development for transportation and land use planning and policy are also examined.

The study is organized into chapters. Chapter II lays the foundations for the study by reviewing theories and empirical research on exurban residential development. The 
emphasis is on the role of journey-to-work in these theories. This chapter also reviews empirical research on metropolitan and exurban commuting patterns. Chapter III discusses the collection of primary and secondary data, the methods of analysis, and the research hypotheses. Chapter IV presents descriptive results clarifying who exurban homebuyers are, why they are moving to exurbia, and how their moves affect commuting. A typology of exurbanites is also developed. Chapter $\mathrm{V}$ analyzes the relationships between exurban living, individual and household characteristics, and commuting time. In addition the relationships between residential location, commuting time, and housing costs are explored. Chapter VI discusses the implications of the study for theories of exurban development and urban form, for transportation and land use planning and policy, and for future research. 


\section{CHAPTER II}

REVIEW OF THE LITERATURE

This study analyzes the ways the decision to live in exurbia influences commuting. It is therefore important to know why people are moving to exurbia before trying to understand their commuting patterns. Thus this chapter reviews theories which might explain exurban residential development before examining literature on metropolitan and exurban commuting patterns.

\section{EXURBAN RESIDENTIAL DEVELOPMENT}

There are a variety of ways of looking at exurban residential development. Urban form theories of Burgess (1925), Hoyt (1939), and Alonso (1960, 1964) examine the locational patterns of urban activities and the societal forces shaping these patterns. Tiebout (1956) analyzes the demand for public goods and services as a determinant of residential location. This section includes a description of each theory, its explanations for exurban development, the role of journey-to-work within the theory, and an evaluation of the theory's relevance to a study of commuting patterns. Studies of suburban and rural residential growth are also reviewed. 


\section{Urban Form Theories}

Burgess (1925) observed that as monocentric cities grew residents separated themselves on the basis of socioeconomic status into concentric zones about the central business district (CBD). The working class lived near the $C B D$ in cheaper older housing vacated by higher income groups. This location also gave them easy access to work in the CBD. Upper income residents built new housing at the edge of the city or in suburban areas, because older housing was not suitable for them and they could afford to commute to the CBD. As the city grew, expansion of the CBD caused nearby working class people to encroach on higher income zones whose residents in turn moved farther out. Thus in Burgess's model, the upper socio-economic class inhabit the outward-moving urban fringe and have the longest commutes to work.

Hoyt (1939) contended that socioeconomic groups lived in sectors rather than concentric rings. Upper income residents preferred areas near superior transportation routes and scenic attractions such as water and hills and away from manufacturing activities. Middle income residents tried to live as close as possible to upper income areas, and lower income persons were left with the least desirable areas. As the city expanded, upper and middle class residents moved outward from the desirable areas, while lower income residents largely moved into older housing. 
Hence in Hoyt's analysis different areas on the periphery of the city may be inhabited by different socio-economic groups. One factor that influences both the extent of the city and the type of people in the area is transportation routes.

Kasarda (1983) sees Burgess's model operating in large American cities where poor and minority residents are concentrated in the urban core and the more affluent live in suburbs. But Burgess's and Hoyt's theories are not adequate explanations of exurban residential development today. Both theories assume a monocentric city and a growing population. Neither condition may be true today. Furthermore, exurban development does not seem to be the inevitable outward movement of cities postulated by these theories. Finally, although both models have a journey-to-work element, this idea is neither central nor well developed.

Alonso's (1960, 1964) bid-rent model of urban structure has journey-to-work as a major component. Alonso used the agricultural land-rent theories of Von Theunen to develop an urban model based on a trade-off between location, accessibility, and all other goods. In the simplest form of the bid-rent model all urban economic activity is at the center of the city. Accessibility therefore includes getting to jobs, shopping, and other activities. However, journey-to-work is often considered the primary type of 
8

travel (Kain 1962) and is the focus of most research using this model.

According to Alonso (1964), households consider the cost of land, of commuting, and of all other goods when selecting a residence. Their budget constraint is therefore:

$Y=P_{z} z+P(d) q+K(d)$

where $\quad \mathrm{Y}=$ household income

$P_{z}=$ price of the composite good

$z=$ quantity of the composite good

$P(d)=$ price of land at distance $d$ from the city center

$q=$ quantity of land

$K(d)=$ cost of commuting to distance $d$

d = distance from city center.

In the monocentric city, housing near the urban center has low transportation costs and high land costs. Near the urban fringe costs are reversed. The cost of the composite good is assumed to be unaffected by distance from the city center.

Central city residents minimize housing costs by consuming small amounts of expensive space and also spend little on transportation. If they desire more space, they most either move farther out or consume less of other goods. Exurban residents can consume larger amounts of land because it is cheaper but must spend more on transportation. Exurbanites can also purchase small, but cheaper lots, in 
order to consume more of other goods. Thus exurbanites could be motivated either by a desire for more space or by a need to economize on housing expenditures.

Muth (1969) concludes that as incomes rise Americans choose more space and other low-density housing amenities despite the additional cost and bother of longer commutes. Rising incomes therefore can result in more households choosing exurban living. However, with this model urban population growth is not essential for exurban development to occur. Rising incomes or declining transportation costs, by themselves, can cause movement to the urban fringe.

There are a number of problems with this approach to modeling exurban development. First, it assumes a monocentric city. Kain (1962) and Evans (1973) have overcome this objection, by expanding the model to include multiple work sites. In their multinucleated versions, CBD workers commute from throughout the region, while suburban workers live close to work. Because the variability of housing costs declines with distance from the $\mathrm{CBD}$, suburban workers gain little by living far from work. Most of the suburban workers will live outward from their workplaces because this is the only way they can take advantage of declining housing costs. Suburban employment can therefore cause an outward shift of residences. While these modifications make the model more realistic and help explain exurban development, they cannot explain the large amount of 
reverse and within ring commuting that is occurring today (Cervero 1986; Fulton 1986).

White (1988) explains most reverse and circumferential commuting by adding the labor market to the analysis. She contends that suburban firms must pay workers more to compensate for commutes that do not provide housing savings. But adding labor markets for all suburban employment centers vastly complicates the model and makes finding equilibrium conditions very difficult (Richardson 1988).

Second, the model assumes that commuting to work is undesirable. Yet Coleman (1978) notes that some people value distance from work more than proximity. Sociological theories of work suggest that moderate length commutes provide a needed separation of home and work (Salomon and Salomon 1984). Herbers (1986) also reports that some people find long distance commuting relaxing and enjoyable. Others contend that people are indifferent about commuting within a range of 3-5 miles from their workplaces (Getis 1969, Clark and Burt 1980) or perhaps even as far as 20 miles (Halvorson 1975). Hoyt (1939) also observed that people prefer to live away from workplaces because of the negative externalities of industry and the positive externalities of scenic locations. In this vein, Yamada (1972) has extended the Alonso model to include quality-of-life as a upward function of distance from work. 
Third, the costs of commuting may be less important in determining residential location than the model implies. Kasper (1983) contends that commuting costs are paid by employers in the form of higher wages. In labor theory workers trade-off accessibility and wages, rather than accessibility and location (White 1986). Commuting costs may also have small impacts on residential decision-making because people frequently underestimate the cost (Mitchelson and Fisher 1981) or they minimize costs by strategies other than moving closer to work. One such strategy is to avoid rush hour congestion. Flexible work hours are one way of avoiding congestion. About one-eighth of the workforce employed by others has the option of flexible hours, and this proportion is growing (Mellor 1986).

Fourth, increasing numbers of people are less concerned with accessibility to the urban area because they do some or all of their work at home or have mobile workplaces (Herbers 1986, Howland 1982). According to the Bureau of Labor Statistics almost 9 million Americans or 8.4 percent of the workforce work at home at least 8 hours per week (Horvath 1986). In addition, the shift to a service economy has resulted in more client-serving jobs with multiple or mobile workplaces.

In sum, because of changes in job locations and in transportation and communication technologies, people may be able to have an exurban lifestyle without making long 
commutes. or they may consider their longer trips a positive, rather than a negative, experience. Hence, other reasons for exurban growth must be investigated.

\section{Demand For Public Goods And Services}

Tiebout (1956) has taken an entirely different approach to residential location by focusing on public goods and services while ignoring jobs and private goods such as residential space. He asserts that people would choose to live where the level of public goods and services best matched their preferences if employment opportunities did not limit residential choice.

In a Tiebout world, exurban development occurs when people desire fewer public services and/or different public goods than cities and suburbs provide. Kasarda (1983) contends this is happening. Certainly most exurban residents do without municipal services like water and sewage treatment (Nelson and Dueker forthcoming). Some worry that exurban demands for police, schools, and other services will escalate over time (Doherty 1984), but tho current evidence is inconclusive (Joseph and Smit 1983). In addition, exurban residents may have greater access to and appreciation for some public goods such as cleaner air, less congestion, and more outdoor recreational opportunities (Stevens 1980).

While the Tiebout model is appealing, its neglect of journey-to-work leaves some questions unanswered. Are 
exurban residents "buying" public goods at the price of higher commuting costs or are they able to enjoy these goods without increased transportation costs? Bell (1974) contends that in a post industrial society people are more interested in quality of life than costs. In that framework, exurbanites would tolerate longer commutes for better living. However, several studies indicate that people may be able to live on the urban fringe without increasing journey-to-work costs because of the suburbanization of employment (Dueker et al. 1983, zimmer $1985)$.

\section{Suburban and Rural Residential Growth}

Another approach to understanding exurban residential development is through empirical studies of residential growth. Because little research has been done explicitly on exurban growth, other models must be used. If exurban development is an extension of suburbia, then the literature on suburban residential growth should be examined. If, on the other hand, exurban development is different from suburban development, the literature on the recent growth of rural areas may be more appropriate. Both are briefly reviewed here.

Suburban Residential Growth. In a thorough historical analysis of suburban residential development in the U.S., Jackson (1985) identifies urban population growth, antiurbanism, racism, and cheap housing as the primary 
motivators for suburbanization. According to Jackson, high personal incomes, low land costs, transportation improvements, new housing construction methods, federal programs encouraging home ownership and automobile use, and the free enterprise system of land and housing development are the factors producing cheap suburban housing.

Anas and Moses (1978) and Muller (1981) add the suburbanization of employment to this list of attitudes, technological changes, and government policies shaping suburban residential choice. Both improved transportation and changing employment locations suggest that changes in journey-to-work have aided suburban residential development.

Hanson (1989) goes farther and contends that a major reason for the extensive spread of urban areas in the United States is the long-term subsidization of automobile use. Although user fees like gasoline taxes and registration fees pay some of the costs of highway construction and maintenance, Hanson argues that automobile use currently receives direct and indirect subsidies equivalent to a gasoline tax of $\$ 1.27$ per gallon. About 42 percent of the subsidies are direct costs such as local property taxes to build and maintain streets and roads and to provide traffic control devices, street lights, and traffic police. The remainirg 58 percent are indirect subsidies including tax breaks for the petroleum industry and externalities such as air pollution and personal injuries. According to Hanson, 
these subsidies have encouraged automobile use and urban sprawl. Without them, cities would be more compact and exurban living less attractive.

To summarize, suburban residential growth has been facilitated by society's attitudes about the ideal place to live, by the low cost of automobile use, by the suburbanization of jobs, by technological advances in housing and transportation, by government programs, and by the market system. Some of the same factors may be influencing exurban development today.

Rural Residential Growth. Frey (1987) has identified two major perspectives on the recent population growth in rural areas--regional restructuring and deconcentration. The perspectives explain rural development in general, and exurban development in particular, in different ways.

The regional restructuring perspective emphasizes changes in the organization and location of economic activities. From this point of view, rural areas are growing primarily because standardized manufacturing is shifting to rural locations with lower labor costs. Exurban residential development would result from jobs, especially manufacturing jobs, shifting to rural and small town locations outside the urban/suburban area.

The deconcentration perspective focuses instead on the expanded residential choices of consumers due to technological and social change. In this view jobs follow 
people to desirable rural locations, or, in the exurban case, people live farther from their jobs. This view is consistent with numerous surveys reporting that most Americans would prefer to live in small towns or rural areas, especially if they would be near a large town or city (zuiches 1981). It is not clear wnether these preferences are latent desires which it has recentiy become feasible to act upon (Wardwell 1980), the same pro-rural biases that influenced suburban development (Carlino 1985, Elazer 1987), or new attitudes about the ideal place to live (Lessinger 1985). Whatever the source of these preferences, many have argued that they have had more influence on nonmetropolitan residential decision-making than economic factors (williams and Sofranko 1980, Zelinsky 1977).

The conclusions from the rural growth literature are similar to those from the suburban literature. Exurban residential growth may be influenced by people's attitudes about the best places to live and stimulated by technological and economic changes.

\section{Summary}

This review of theories suggests a variety of factors that cild be supporting exurban residential development. They include:

1. Pro-rural attitudes about the ideal place to live

2. High household incomes which allow greater residential choice 
3. The desire for lower taxes or different public goods and services than cities and suburbs provide

4. Metropolitan population growth

5. Lower housing costs at greater distances from the city center which offset higher transportation costs of living farther out

6. Cheap personal transportation

7. The deconcentration of employment

8. The pleasures of rural driving

9. Work schedules that allow more flexibility in commuting or require fewer trips to a fixed work location

The first four factors are not directly related to commuting, but the rest are. The remainder of the literature review turns to research on commuting patterns.

METROPOLITAN AND EXURBAN COMMUTING PATTERNS

This section reviews recent metropolitan commuting literature and the limited research which has been done explicitly on exurban commuting.

\section{Metropolitan Commuting Research}

Metropolitan commuting patterns have been changing. These patterns have been evolving from a simple set of flows converging on the $\mathrm{CBD}$ into a much more complex arrangement which includes extensive intrasuburban and reverse flows. In 1980, the most common type of work trip in metropolitan 
areas had both origin and destination outside the central city; 40.1 percent of all metropolitan work trips took place totally within suburbia. Only 20.1 percent were from suburb to central city and 33.0 percent were within the central city while 6.8 percent were reverse flows from central city to suburbs (Bureau of Census 1984). This shift in commuting patterns is the result of changes in the locations of homes and jobs, in the kinds of occupations and associated work schedules, and in the types of individuals within the workforce.

Changes in the spatial Patterns of Jobs and Residences. Both people and jobs have been deconcentrating for some time. While some predict that this will ultimately result in short commutes for nearly everyone (Leven 1979), this is not yet the case. People still commute considerable distances because CBD's cften retain a surplus of jobs over residents, jobs and people do not necessarily deconcentrate at the same rates, and the skills of the residents of a zone may not match the jobs within or near that zone.

For example, zimmer (1985) found many changes in residential and job locations in the Providence, Rhode Island, Standard Metropolitan Statistical Area (SMSA) between 1967 and 1980. In that period both the central city and inner suburbs lost population while the outer suburbs grew rapidly. Job growth was greatest in the inner suburbs, with a decline in the central city and a growth rate much 
slower than population growth in the outer suburbs. As a result more residents of all zones found jobs in the inner suburbs. Outer suburban residents increased their commuting to all zones, but especially to the inner suburbs and outside the metropolitan area. Mean distance to work, but not time, increased for residents of all zones--by about 8 percent for residents of the inner suburbs and over 30 percent for central city and outer suburban residents. Time to work remained about the same despite the increasing trip lengths. zimmer attributes faster trips to less congestion on suburban highways.

Hutchinson's (1986) analysis of commuting in the Toronto Census Metropolitan Area between 1971 and 1981 found somewhat different results. Mean commuting length decreased in most outer zones because manufacturing and some office jobs were moving there from the $C B D$ and suburban service jobs were growing. At the same time, several outer zones with superior rail and freeway access to the CBD had increases in mean trip lengths because $C B D$ workers moved to these areas. The number of reverse commuters, especially from Toronto's ethnic neighborhoods to decentralized manufacturing, also increased making the 1981 pattern quite complex.

Cervero (1986) reports that deconcentration of jobs and residences does not always ease the flow of traffic. The suburbs of Atlanta, Houston, San Francisco, and a number of 
other areas are experiencing heavy traffic flows in all directions on their freeways. In these cases, rush hour congestion has come to suburbia along with jobs and people.

These studies illustrate that deconcentration of jobs and residents does not produce uniform results. It can shorten commuting if jobs move closer to residents or vice versa. It can lengthen commuting if there is a mismatch between the location of jobs and residents or if the number of commuters using the same routes exceeds capacity.

Changes in occupations and Work Schedules. The shift from an industrial to a service economy affects commuting because it influences the location of jobs, the occupational structure, and working conditions. For the past 25 years the number of goods-producing jobs has remained fairly constant while the number of service-producing jobs has increased (Kutscher and Personik 1986). Many of the new service jobs have been created in suburbs as services have moved closer to the populations they serve and as CBD's have become more specialized business centers. Since the impact of job decentralization has already been discussed, this section will focus on changes in job characteristics.

White collar workers have traditionally had longer commutes than blue collar workers. This may be a result of occupation's influence on income, on where one might find work, and where one may desire to live. For example, Gera and Kuhn (1981) demonstrate that the spatial structure of 
Toronto in 1971 allowed blue collar workers to commute shorter distances than white collar workers. In other words, blue collar workers were more likely to find jobs in or near their residential zones than white collar workers who frequently had to commute to the CBD. Since a greater proportion of the workforce is now white collar, this may mean that average commuting time is increasing.

However, occupation may also have an impact on one's propensity to commute. Gera and Kuhn (1981) also found that some occupational groups, particularly skilled blue collar workers, traveled considerably longer distances than the spatjal structure implied they must. Cubukgil and Miller (1982) attribute this to both the high income of skilled blue collar workers (the same as middle managers and semiprofessional) and to a greater propensity to commute. In their analysis occupational groups have the following ranking on sensitivity to travel time (beginning with lowest sensitivity): 1 ) skilled blue collar/foreman, 2) high management./professional, 3) middle management/semiprofessional, 4) supervisor, 5) semi/unskilled blue collar, and 6) clerical/sales/services. The disparate ranking of white collar workers suggests that the assumption that more white collar jobs means longer average commutes may be too simple. If exurban living does in fact require longer commutes, the occupational groups with lower sensitivity to travel time, namely skilled blue collar workers and managers 
and professionals, should be more likely to be moving to exurbia.

Another factor influencing commuting time may be modifications in work schedules. The shift to a service economy has changed the hours and places that many people work. While the majority of Americans still work a forty hour, 8-5, Monday-Friday week, this is changing. Retailing and service businesses must be open when their customers can shop or utilize their services. Thus one-fourth of the labor force now works on Saturday and one-eighth on Sunday. One-sixth of the full-time workers and one-half of part-time workers work evenings or nights. Over 12 percent of fulltime wage and salary workers have flextime schedules allowing them to vary the time they report to work. Another 11 percent of the workforce is self-employed and may therefore have some flexibility in work hours. In addition 8.4 percent of the workforce spend at least eight hours a week doing some of their regularly scheduled work at home (Flaim 1986). Furthermore many service jobs require going to the customer. Thus more workers have traveling jobs and may not need to report to a fixed place of work daily.

These changes mean that some people are avoiding rush hour traffic by working different hours and days, others commute less often by doing some of their work at home, and some have no regular commutes. Because these changes affect various occupational groups differently, they may influence 
the type of worker who is moving to exurbia. For example, managerial, professional, and technical workers are more likely to have flexible hours and work at home, and these occupation groups may therefore be more prevalent in exurbia.

Changes in Members of the Workforce, More women are participating in the workforce, and most studies indicate that women commute shorter distances than men. Women's shorter commutes have been assumed to be related to their lower wages, shorter work weeks, and home and childcare responsibilities (Madden 1981). In addition, Gera and Kuhn (1981) and Singell and Lillydahl (1986) both found that male-dominated occupations have longer commutes than femaledominated jobs irrespective of the gender of the job holder. It may be that firms with traditionally female jobs locate near female workers.

with the majority of married women in the workforce, many households have two people commuting to work. Because of dispersed workplaces, the spouses are likely to work in different locations. It has often been assumed that the man's job has determined residential location while residential location has constrained women's jobs choices. Singell and Lillydahl (1986) confirm that two-wage earner families who move are most likely to keep the husband's commute constant while increasing the wife's commute. 
If moving to exurbia means longer trips for both earners, these findings suggest that two-wage earner households would not move there. If, on the other hand, exurban living does not require longer commutes, especially for primary wage earners, exurbia might be attractive to two-wage earner households.

Conclusions about the changing influences on commuting. Recent studies by Madden (1981), singell and Lillydahl (1986), and White (1986) have examined how combinations of these factors--residential and job location, occupation and work schedules, increased female participation in the workforce--plus other factors such as the number of children are influencing the commuting distances of men and women. of particular interest to these study is how residential choice combines with household and individual characteristics to influence commuting patterns.

Because these studies had different objectives and used different sets of data, the results are not always comparable. Furthermore when the results can be compared, they are not always consistent. Nonetheless some general conclusions can be drawn about family structure, residential location, and commuting.

The structure of the family and the home and work roles of family members do influence the residential location of households and the distances individuals are willing to commute. For example, children frequently increase the 
distances men commute, especially if their spouses are not employed, while decreasing the distances women commute. Households with children generally prefer more suburban locations where lots are larger and cheaper but are farther from male wage earners' jobs. Female workers with children may have shorter commutes because they work fewer hours, have more home responsibilities, or hold jobs which are more frequently located in the suburbs Madden (1981), in particular, concludes that the household division of labor is more important than job characteristics in explaining commuting patterns.

In sum a variety of factors related to commuting could be influencing exurban residential development. The decentralization of jobs may make it possible to live in more rural areas without longer commutes. Certain occupational groups, such as blue collar workers, may live in rural areas because they don't feel that commuting is as much of a burden as other workers. Flexibility in work hours and places may encourage some to move to more remote locations. Depending on whether other factors produce a longer or shorter commute, different family types may be attracted to rural living. Because so many factors are interrelated it is difficult to predict what type of people are moving to exurbia. 


\section{Exurban Commuting Research}

studies on the actual commuting patterns of exurban residents are scarce. Some studies use commuting data to help define exurbia and one compares the commuting distances of exurbanites and suburbanites.

Troughton (1981) used data on commuting flows and people who work at home (assumed to be farmers in this study) to define and map three zones--urban, rurban (in between urban and rural), and rural--in an area extending 35-45 miles from London, ontario. London is a city of 223,000 residents separated from other southern ontario cities by prime agricultural lands. The urban places were the primary destinations of commuters and included the city of London, all small towns, and two outlying townships with manufacturing plants. The rural areas were primarily agricultural with limited commuting to other areas. In between were the rurban areas with the highest rates of commuting out of the immediate area. All the rurban areas where clustered around the city of London showing strong attraction to the city for jobs and other purposes.

Turning to the U.S., Berry and Gillard (1977) have mapped the commuting fields of all U.S. Standard Metropolitan Statistical Areas (SMSA's) using 1960 and 1970 census data. They demonstrated that commuting ranges were expanding. However, Taaffe, Gauthier and Maraffa (1980) in a study of Appalachian ohio found that in this region 
commuting ranges were intensifying rather than extended. In other words, more people in the exurban area were commuting to SMSA's, but the exurban areas were not spreading farther into the countryside. Fisher and Mitchelson (1981) in a study of Northeast Georgia-Northwest South Carolina found both expansion and intensification occurring.

Although Berry and Gillard's maps have not been replicated for the 1980 census, nonmetropolitan counties adjacent to SMSA's grew rapidly in the 1970's (Richter 1985). Many of these counties have subsequently been added to SMSA's reflecting both their population growth and their commuting ties to the urban/suburban area.

In the one study which compares exurban and suburban commuting distances, Dueker et al. (1983) used rural nonfarm residents within SMSA's as their definition of exurban residents. They found no significant differences in the commuting lengths of exurbanites and suburbanites or among various types of exurbanites where the categories are based on housing type and cost and household income.

None of these studies clearly delineates exurbia. Troughton's rurban category may mix suburban and exurban areas since density is not considered. The others have adopted convenient, though imprecise, boundaries. Since only 10 percent of the land area within SMSA's is urbanized (Alonso 1978), considerable exurban development can occur within SMSA's. Dueker et al.'s (1983) study was of exurbia 
within SMSA's. Exurban development can also extend into adjacent nonmetropolitan counties. Taaffe, Gauthier, and Maraffa (1980) and Fisher and Mitchelson (1981) focused on that part of exurbia.

Furthermore, only the study by Dueker et al. (1983) attempts to identify what types of households are living in exurbia, and their analysis is speculative rather than confirmatory. For example, they assume that households seeking the privacy and seclusion of large exurban lots have both high incomes and expensive houses, but do not have data to test that hypothesis.

Thus only a vague picture of exurbanites and their commuting behavior currently exists.

\section{CONCLUSIONS}

Exurbia is by definition a place where a portion of the population commutes to urban and suburban areas. Yet the previous review points out that little is known about this commuting. It seems clear that exurbanites highly value rural amenities. What is not known is how they value travel time. The literature review suggests several possibilities:

1) Affluent households who value both travel time and exurban living highly may be willing to commute long distances in order to have the desired residential location. This is the original image of exurbia (Spectorsky 1955) and the conclusion of the Alonso type urban model. 
2) The decentralization of employment may mean it is possible to move to exurbia without an increase in commuting time or distance. In other words, exurbanites' propensity to commute may not differ from that of suburbanites. Some empirical research supports this view.

3) Time and distance-saving strategies, such as working at home part of the time, may enable people who value both exurban living and travel time highly to live farther from work without an increase in weekly travel time. This view has not been investigated.

4) A household's preference for exurban living may be reinforced by a low valuation of travel time (Beesley and Dalvi 1974). This possibility has not been examined.

5) Commuting may serve positive purposes, such as providing a needed separation between home and work or be a form of leisure, the value of which exceeds the cost of travel up to a certain distance. For some households, exurbia may be within the range where commuting adds, rather than subtracts, from total utility. There is evidence that a zone of indifference to commuting exists but its size is debated.

6) Some people may not commute on a regular basis to a fixed workplace either because they do most of their work at home or work by traveling to their customers' sites. Such people have no journey-to-work, in the usual sense, to consider when chosing an exurban residence. These people do 
not fit into a standard commuting behavior analysis and have not been studied.

This study surveys households buying homes in exurbia to determine who they are, why they live there, and how this affects their commuting. The result should be a much clearer picture of exurbanites and their commuting patterns. 
CHAPTER III

\section{RESEARCH METHODS}

This study analyzes and compares the emerging commuting patterns of exurban, small town, and suburban residents using the Portland, oregon, region as a case study. The analysis is based on a mail survey of 1408 households who purchased homes in the exurban and suburban areas around Portland in 1987. A survey of households who recently moved should produce a clearer picture of emerging trends than a survey of the same number of households in the general population. Recent movers who rent or who own mobile homes and rent spaces in mobile home parks are not included in the study because of the practical problems of locating them and the theoretical difficulties of including the different processes of owning and renting in one analysis.

A case study approach is used because secondary data sources such as the American Housing Survey do not clearly identify exurban households. For example, Dueker et al.'s (1983) analysis of rural nonfarm residents within metropolitan areas used American Housing Survey data that only partially captured exurban residents. Nonmetropolitan exurbanites could not be included. Although the American Housing Survey's recent addition of geographic zones make it 
a promising source of data where county lines reasonably approximate the suburban/exurban boundary, this will not work in western states where counties are large. Local surveys are currently the only way to obtain data in these areas.

Portland, Oregon, was selected as a representative urban field because it is a large metropolitan area with a moderate growth rate (Price 1987), and it has followed the national trends of increasing suburbanization of jobs and people which result in more commuting within suburbia (Roberts 1986). The study results should, therefore, be fairly typical of large United states urban areas.

But oregon does have statewide land use planning that restricts urban sprawl, and therefore axurban development, more than any of the other 48 contiguous states. On the one hand, this aids the study since a metropolitan urban growth boundary (UGB) clearly separates suburban and exurban land uses. On the other hand, it means the generalizability of the results will be tempered. It is thus important to understand how the UGB relates to exurban development.

Every city in Oregon and the Portland metropolitan area as a whole has a UGB which separates urban and suburban activities from more rural pursuits. Figure 1 shows the location of the Portland metropolitan UGB. Land outside the UGB is zoned for exclusive farm or forestry use with restrictions on parcelization and home construction, and for 


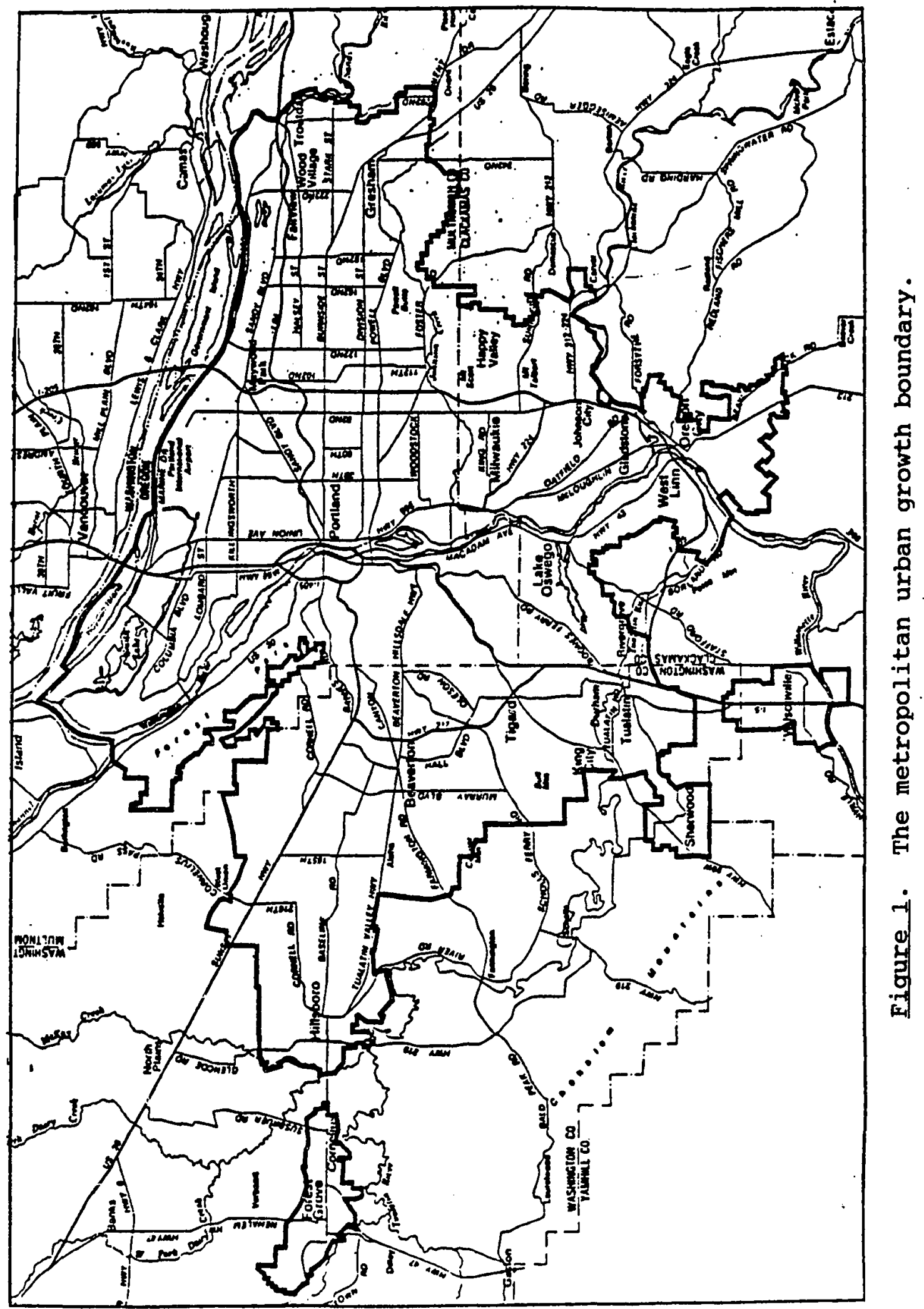


rural residential or nonexclusive agriculture/forest uses with minimum lot sizes of 5,10 , and 20 acres (Nelson 1988). It is this zone of rural residential lots mixed with agriculture and forest lands within the commuting range of urban and suburban jobs that is called exurbia.

The rural area also contains small towns with their own UGB's. These small towns offer many of the same attractions as rural areas while allowing smaller lot sizes and providing urban services such as sewer systems. The larger small towns also provide commercial and industrial jobs.

Because the metropolitan UGB allows room for suburban growth, low density development is also occurring inside the UGB. This development will nonetheless be classified as suburban because this land is committed to eventual suburban uses. This area is what Healy and short (1981) describe as the urban fringe or transition zone, rather than exurbia.

The commuting patterns of Portland's exurban residents may be affected by land use planning because it restricts the supply of land available for certain uses (Healy and Short 1981). For example, the cost of large lots may exclude some typical exurban buyers from the market. But some of these lower income households may be locating in small towns or on smaller rural properties which predate more restrictive land use regulations. Rural jobs may also be less prevalent than in other regions because commercial and industrial development is directed to lands within the 
UGB's of the small towns of exurbia or to the urban/suburban area.

\section{STUDY AREA}

The study area, illustrated in Figure 2, includes part of the Portland Standard Metropolitan Statistical Area (SMSA) (Washington County, the eastern portion of Yamhill County, and the western half of clackamas county), part of the Salem SMSA (northern Marion County), and the southern half of nonmetropolitan columbia county. This area includes all exurban census block groups or enumeration districts with developable land where at least ten percent of the resident workers commute to an oregon metropolitan area.

Two counties in the Portland SMSA are not included in the study. Although Multnomah County contains suburban and rural lands in addition to the central city of Portland, it is omitted because county land use regulations virtually exclude exurban residential development and there are ample suburban cases in Clackamas and washington Counties. clark County, Washington, is not included because of the different land use laws in that state.

To simplify the sampling process, census boundaries were modified slightly to conform with the ways county assessor's offices organize their records. In Marion and Columbia Counties, assessor's districts which approximate the census districts were used. In clackamas and Yamhill 


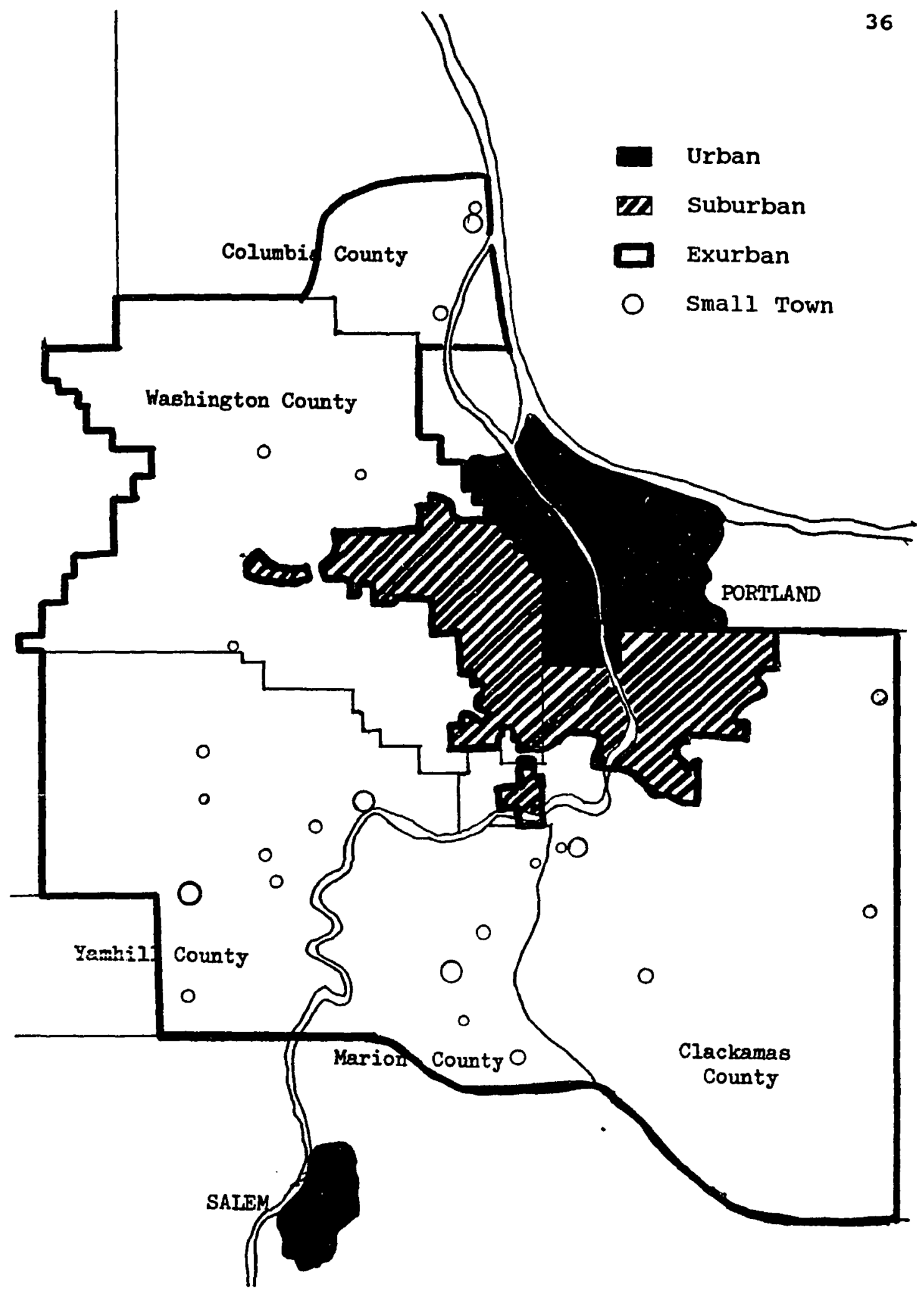

Figure 2. The study area. 
Counties the rivers, roads, and other irregularities of the census boundaries were straightened by using township lines. Washington County required no adjustments since the entire county is in the study area. For the most part these boundary modifications affected agricultural and forest lands where few homes are located. They did, however, add the town of Estacada in Clackamas county to the study area and delete Vernonia in Columbia County.

The study area is divided by the metropolitan UGB into suburban and exurban zones. The cities of Wilsonville and Forest Grove whose UGB's are nearly contiguous with the metropolitan UGB are included in the suburban zone. Scattered throughout the exurban zone are 24 small towns ranging in size from 110 to almost 16,000 residents. Table I list the small towns in the study area.

\section{SAMPLING}

Names and address of households who purchased and occupied homes in the study area in 1987 were derived from lists of property sales kept by each county assessor's office. Oregon assessors keep accurate records of real property transactions to aid in establishing assessed value.

The basic sampling procedure was to 1) sort out the potential residential sales, 2) verify that the property was owner-occupied, 3) divide the sales into exurban/small town and suburban categories and 4) select the samples. The 
TABLE I

INCORPORATED SMALL TOWNS WITHIN THE EXURBAN STUDY AREA WITH 1987 POPULATION ESTIMATES

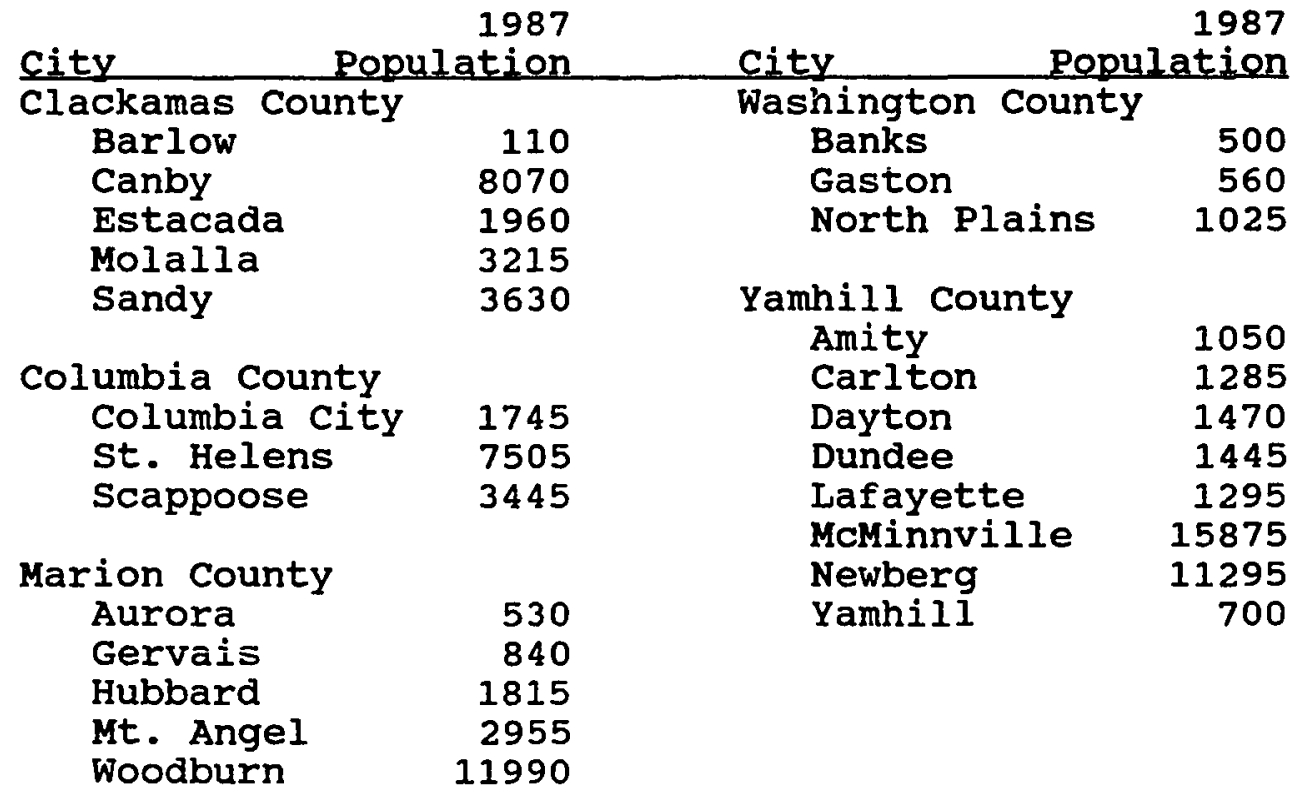

Source: Center for Population Research and Census, Portland State University

detailed strategies for doing this varied from county to county because of differences in record keeping methods, levels of computerization, provisions for public access to records, and willingness to help a researcher with unusual requests. The general process is described next with some notes about county variations.

The first step was to identify potential residential sales. All sales of single-family residential lots plus rural tracts, farms, and forest land with improvements were initially selected. Multi-family, commercial, industrial, and all vacant lands were omitted. Farm and forestry lands 
were included in the analysis since households living there could derive their primary income from non-farm and nonforestry jobs.

The selected sales were then checked to determine if the owner lived on the property. (In practice, screening for owner-occupied homes was frequently done after selecting the sample because it usually required looking up individual property records on microfiche. This procedure assumes that the sample has the same frequency of owner-occupied homes as the original list.) This process was not perfect. For example, households with post office boxes in the same area as their property were kept on the lists although it was not certain that they lived on the property. In Columbia county owner-occupancy could not be determined because the county mails tax statements to the property address as long as it is a valid mailing address regardless of who lives there. In Yamhill County some people who moved after purchasing their home were included in the sample because sales printouts which included both situs and mailing addresses were the only records checked.

Next Washington and Clackamas County sales were divided into exurban/small town and suburban groups based on the metropolitan UGB. Since neither county's property records identified parcels as inside or outside UGB's, it was necessary to do this manually using plat maps and tax lot numbers. 
Once the lists of 1987 exurban/small town and suburban home sales were assembled, systematic random samples were selected. Orie out of every four exurban/small town sales and one out of every ten suburban sales were selected to obtain samples of approximately 750 households each. (The sampling ratios for clackamas County were slightly higher-3:10 for exurban/small town sales and 1:8 for suburban--to adjust for the lack of January and February 1987 sales data. This procedure yields samples of the size they would have been had the number of sales per month been constant. Constant monthly sales was an expedient, though somewhat unrealistic, assumption.) Table II shows the size of the samples for each county.

TABLE II

SAMPLE SIZES

$\begin{array}{lr}\text { Area (Sampling Rate) } & \text { Sample Size } \\ \text { Exurban/Small Town }(1: 4) & \\ \text { Clackamas } & 328 \\ \text { Columbia } & 70 \\ \text { Marion } & 90 \\ \text { Washington } & 71 \\ \text { Yamhill } \quad & 180 \\ \quad \text { Total } & 739 \\ \text { Suburban }(1: 10) & \\ \text { Clackamas } & \\ \text { Washington } & 295 \\ \quad \text { Total } & 444 \\ \text { All Areas } & 739\end{array}$




\section{DATA COLLECTION}

Each household in the sample was contacted by mail to learn about their move and its effects on household members' travel to work. Dillman's (1978) total design method was used in designing and implementing the mail survey. The primary data from the survey were matched with secondary data from the county assessor's records including purchase price and property tax rates and with some neighborhood characteristics obtained from other public data sources.

\section{Primary Data}

Survey Design. The questionnaire (see Appendix A) was based on one used in a related study by Drs. Arthur $\mathrm{C}$. Nelson and David $s$. Sawicki of the Georgia Institute of Technology. Their questionnaire was modified using ideas from the American Housing survey, a supplement to the May 1985 Current Population survey which focused on work schedules, an employee survey done by the Regional Research Institute for Human Services at Portland State University in 1987, and a 1987 campus community transportation survey developed by the Parking office and the center for Urban Studies at Portland State University. The draft survey questionnaire was reviewed by the dissertation committee, revised again, and pilot tested using a sample of 40 Washington county households who purchased homes in early 1988. This pilot survey had a 57.5 percent response rate. 
This was considered satisfactory since the main survey would include additional followup mailings to non-respondents and would not be done as close to major holidays as the pilot study. The pilot survey responses also suggested some changes in questions which were used in the final survey questionnaire.

Survey Implementation. Surveys and a reminder postcard were mailed to the households in the sample on the schedule in Table III. Each survey mailing included a personalized cover letter and a business reply envelope. Copies of the letters and postcard are included in Appendix $A$. The post office returned a few of the letters because of address problems. These were checked for clerical or other errors and when corrected were remailed with followups on a similar schedule.

TABLE III

MAILING SCHEDULE FOR SURVEYS

Date Type of Mailing

February 23 Initial mailing of surveys

March 3

Postcard thank you/reminder to all households

March 16

Followup surveys sent to non-respondents

April 20

Followup surveys sent to non-respondents

These mailings followed Dillman's

(1978)

recommendations except that the last mailing went out one week later than advised and did not use certified mail. The delay in mailing was a result of needing more preparation 
time than allocated, but coming so late in the process it should not have affected returns. Certified mail was not used because this technique assumes that someone will be at home to receive the certified letter or, at least, can conveniently pick it up at the neighborhood post office. with numerous two-worker households in the early returns, this did not seem to be a reasonable assumption.

Instead of certified mail, a variation of a procedure successfully used by Drs. Nelson and Sawicki (personal correspondence 1988) was employed. Standard ink stamps were purchased and used on the envelope and letter. To entice people to look at another mailing a stamp with "What Happened??" in red ink and a second stamp with a round sad face in blue was used on the lower left hand corner of the envelope. A third stamp with a blue "Thank you" and a fourth stamp with a red smiling face was stamped at the bottom of the cover letter.

Survey Response. Table IV reports the sequence of mailings and returns. It should be noted that bulk mailing was used with the postcards. The postcards generated more phone calls than any of the other mailings, and these calls came between one and two weeks after the mailing. This indicates that it took a week or more for the postcards to be delivered. Hence week 2 returns in Table IV should not be attributed to them. In fact, the followup mailing on March 17 should have been delayed about a week to allow the 
TABLE IV

COMPLETED SURVEYS RETURNED EACH WEEK

\begin{tabular}{|c|c|c|c|}
\hline Returns by week & Number & Percent & $\begin{array}{l}\text { Cumulative } \\
\text { Percent }\end{array}$ \\
\hline Week 1 & 353 & 23.98 & 23.98 \\
\hline
\end{tabular}

$\begin{array}{rrrr}\text { Week } 2 & 116 & 7.8 \% & 31.7 \% \\ \text { Week } 3 & 60 & 4.1 \% & 35.8 \%\end{array}$

Followup surveys mailed March 17

$\begin{array}{rrrr}\text { week } 4 & 220 & 14.9 \% & 50.7 \% \\ \text { Week } 5 & 79 & 5.3 \% & 56.0 \% \\ \text { Week } 6 & 22 & 1.5 \% & 57.5 \% \\ \text { Week } 7 & 13 & 0.9 \% & 58.4 \% \\ \text { Week } 8 & 7 & 0.5 \% & 58.9 \%\end{array}$

- - - - Followup surveys mailed April 20-- - -

$\begin{array}{llrl}\text { Week } 9 & 35 & 2.4 \% & 61.3 \% \\ \text { Week } 10 & 29 & 2.0 \% & 63.3 \% \\ \text { Week } 11 & 7 & 0.5 \% & 63.8 \% \\ \text { Week } 12 \text { or later } & 7 & 0.5 \% & 64.2 \%\end{array}$

postcards to have their full effect. Unfortunately, by the time this was evident, it was too late to postpone the mailing.

The rates of response in Table IV are similar to those reported by Dillman (1978) except for the final mailing where the technique differed. He reported that final mailings using certified mail increased response rates on average from 59.0 percent to 72.4 percent. The results here were on target at 58.9 percent before the final mailing, but 
did not do as well with the last mailing boosting the response rate to only 64.2 percent.

These response rates need some adjustment because some of the households in the sample should not have been included. Thirty households (2.0 percent of the sample) contacted us to report that they did not purchase and move into a new home in 1987. Of those, eight bought houses to rent; four refinanced, bought the rental they were living in, or purchased additional land; and seventeen did not provide enough information to determine why they were mistakenly on the sampling lists. The errors may have occurred because some deed transactions other than sales appeared on the assessors' lists, the process of identifying owner-occupied homes was not perfect, and clerical mistakes could have been made when matching sales information with property addresses. All of these households were dropped from the sample.

In addition letters returned by the post office and notes from some people indicated that forty households (2.7 percent of the sample) had moved again or could not be located. Those households were also deleted from the sample since they would not have been included if their change of address had been discovered while assembling the lists of home purchasers. A few households indicated that they had recently moved again but completed the survey with appropriate information. These surveys were kept in the 
sample. These deletions and final sample sizes are summarized in Table $\mathrm{V}$.

TABLE V

ADJUSTED SAMPLE SIZES

\begin{tabular}{|c|c|c|c|c|}
\hline Area & $\begin{array}{c}\text { Original } \\
\text { Sample Size }\end{array}$ & $\begin{array}{l}\text { Not Home } \\
\text { Purchaser }\end{array}$ & $\begin{array}{l}\text { Moved } \\
\text { Again }\end{array}$ & $\begin{array}{c}\text { Adjusted } \\
\text { Sample size }\end{array}$ \\
\hline \multicolumn{5}{|c|}{ Exurban/Small Town } \\
\hline Clackamas & 328 & 10 & 5 & 313 \\
\hline Columbia & 70 & 1 & 2 & 67 \\
\hline Marion & 90 & 1 & 5 & 84 \\
\hline Washington & 71 & 1 & 1 & 69 \\
\hline Yamhilí & 180 & 11 & 12 & 157 \\
\hline Total & 739 & 23 & 24 & 690 \\
\hline \multicolumn{5}{|l|}{ Suburban } \\
\hline$\overline{\text { Clackamas }}$ & 295 & 3 & 4 & 288 \\
\hline Washington & 444 & 3 & 11 & $\underline{430}$ \\
\hline Total & 739 & 6 & 15 & 718 \\
\hline All Areas & 1478 & 30 & 40 & 1408 \\
\hline
\end{tabular}

Taking these revised sample sizes into account, Table VI shows the final rates of return. The total response rate of 67.3 percent is close to Dillman's (1978) final average rate of 72.4 percent for surveys of the general public. As Table VI also shows the rates of return are not uniform for all areas. They range from 61.0 percent in exurban Clackamas county to 81.2 percent in suburban exurban Washington County. Overall suburban returns are higher than exurban although this is not true for each county.

Table VI also reveals that 460 households comprising 32.6 percent of the sample declined to participate. There is some evidence that certain groups of people were more likely to have not responded. 
TABLE VI

FINAL RATES OF RETURN BY SUBAREAS

$\begin{array}{llll} & \text { Adjusted } & \text { Number of } & \text { Rate of } \\ \text { Subarea } & \text { Sample Size } & \text { Returns } & \text { Returns }\end{array}$

Exurban/Small Town

Clackamas 313

Columbia $\quad 67$

Marion

Washington

Yamhili

Total

67
84

69

$\frac{157}{691}$

Suburban

Clackamas

washington

Total

All Areas

288

430

718

1408
191

42

59

56

$\frac{96}{444}$

188

$\underline{316}$

504

948
61.08

62.78

$70.2 \%$

$81.2 \%$

$61.1 \%$

64.28

First, about half of the thirty-five households who wrote or called explicitly declining to participate gave reasons for not filling out the survey. Eight retired/ elderly households felt that they had little to contribute to the study since they did not travel to work, four households thought the questions were too personal, three were concerned their personal safety might be compromised by revealing when they go to work and come home, and one elderly person was too ill to complete the form. Thus households who did not reply might include more elderly/retired people and some people who are especially concerned about home security.

Second, some types of respondents had difficulties answering the travel-to-work questions. People whose place of work varies added comments to many questions and reported 
that the survey did not fit them well. This group included sales representatives, long-distance truck drivers, and construction contractors and workers. A few people also reported difficulties with these questions because of holding two jobs. There probably were others who found the survey questions perplexing and simply gave up.

Third, some respondents felt they had little to contribute, although they did fill out the surveys. This was particularly true of households who moved short distances and stayed in the same neighborhood. Other short distance movers may not have made the effort to reply.

Fourth, a number of the non-respondents have Asian, Hispanic, or other distinctly ethnic names and may have had language difficulties or different cultural attitudes about surveys and, therefore, did not respond.

While non-responses by retired households, workers with variable workplaces, short distance movers, and others may result in underestimating their presence in the study area, it should not bias the commuting results. Retired households are not in the workforce, and most of the people having difficulty with the survey form do not meet the study's definition of commuters.

A more serious bias would exist if certain socioeconomic groups were under-represented in the responding sample. Fortunately a measure of socio-economic status, namely purchase price of homes, was obtained from the county 
assessors' records. Table VII summarizes the housing prices of respondents and non-respondents and shows little difference between the two groups in either exurban/small town or suburban areas. Thus the responding sample should accurately reflect the commuting experiences of recent home purchasers in the study area.

TABLE VII

PURCHASE PRICE OF HOMES OF RESPONDENTS AND NON-RESPONDENTS BY SUBAREAS

\begin{tabular}{lrrrrr} 
& \multicolumn{2}{c}{ Exurban/Small } & Town & & \multicolumn{2}{c}{ Suburban } \\
\cline { 2 - 3 } Price & \multicolumn{1}{c}{$R$} & NR & & \multicolumn{1}{c}{ RR } \\
\hline$\$ 0-\$ 25,000$ & $2.9 \%$ & $3.6 \%$ & $1.6 \%$ & $1.4 \%$ \\
$\$ 25,001-\$ 50,000$ & $31.5 \%$ & $31.6 \%$ & & $13.9 \%$ & $15.8 \%$ \\
$\$ 50,001-\$ 75,000$ & $35.4 \%$ & $38.8 \%$ & $38.3 \%$ & $35.8 \%$ \\
$\$ 75,001-\$ 100,000$ & $18.7 \%$ & $13.6 \%$ & $25.8 \%$ & $24.6 \%$ \\
$\$ 100,000-\$ 200,000$ & $10.8 \%$ & $10.4 \%$ & $19.2 \%$ & $19.1 \%$ \\
$\$ 200,001-\$ 500,000$ & $0.7 \%$ & $2.0 \%$ & $1.2 \%$ & $3.3 \%$ \\
Mean price & & & & \\
Median price & $\$ 67257$ & $\$ 68662$ & $\$ 81044$ & $\$ 86580$ \\
& $\$ 60950$ & $\$ 57000$ & $\$ 73225$ & $\$ 73500$ \\
& & & & & \\
& $n=444$ & $n=250$ & $n=504$ & $n=215$ \\
\hline
\end{tabular}

$\mathrm{R}=$ responding household

$\mathrm{NR}=$ non-responding household

\section{Secondary Data}

Survey data from each household were matched with secondary information obtained from several sources. The assessors' offices provided the purchase price of homes and information on property tax codes and rates. This information was used to determine whether the property was in an incorporated city and its school district. School district per pupil expenditure information was obtained from 
the Oregon Department of Education. Each household was also assigned a distance to Portland's central business district using the Metropolitan Service District's traffic analysis zones and distance data.

\section{DATA ANALYSIS}

Two types of analysis are used. First descriptive statistics are used to clarify the types of households who purchased homes in each part of the study area, the household's view of the role of journey-to-work in their decision to move, their job locations and other work characteristics, and the characteristics of their commuting trips. A set of exurban household types is also developed using k-means cluster analysis.

Regression analysis is then used to clarify the relationship between commuting time and the commuters' residential location and individual, family, and job characteristics. Another regression equation is used to determine the impact of residential location on housing prices. The trade-off between housing prices and transportation is then examined.

originally, I had assumed that residential location and commuting time are simultaneous decisions requiring a twostage least squares estimation (2SLS). However, the hypothesized relationship between the two variables did not hold. Housing price had no impact on commuting time whether 
entered directly into a ordinary least squares estimation (OLS) or estimated first in a 2SLS procedure. Therefore commuting time and price are estimated separately using oLS.

\section{RESEARCH HYPOTHESES}

The analysis tests the following hypotheses about exurban development and journey-to-work:

1) The weekly commuting time and the propensity to commute of exurbanites is not significantly greater than that of suburbanites.

2) The decentralization of employment permits many to live in exurbia without longer commutes than suburbanites.

3) Exurbanites are more likely to work flexible hours than both suburbanites and the average U.S. worker and to use that flexibility to decrease commuting time.

4) Exurbanites are more likely to work at home at least 8 hours a week (excluding agricultural work) than suburbanites and the average U.S. worker and to use working at home to decrease their number of commuting trips.

5) Exurbanites are more likely to use car and van pooling than suburbanites.

In addition the following exurban subgroups will be identifiable:

6) High income households with professional, managerial, and technical occupations and more expensive 
homes are most likely to utilize time-saving strategies such as flextime and working at home.

7) Lower income households living in mobile homes or other less expensive housing have a greater than average propensity to commute.

The next chapters present the results and discuss whether these hypotheses were supported. 
CHAPTER IV

DESCRIPTIVE RESULTS

Commuting trips are usually thought of as by-products of the major decisions of where to live and where to work. These decisions are influenced by characteristics of the individual and of his or her household. It is important to know who exurbanites are and what they are seeking by moving to exurbia before examining their commuting trips.

This chapter is divided into five sections. The first section sketches a portrait of exurban home buyers and compares them with their suburban and small town neighbors. The second section looks at their reasons for buying an exurban home and how these reasons differ from those of other home buyers. The third section delves into the commuting trips of employed adults and the ways that moving has changed these trips. The fourth section develops a typology of exurban households based on commuting times and some household and job characteristics. The final section relates the descriptive results to the research hypotheses.

The results are presented for three residential locations--exurban, small town, and suburban. The area outside the UGB is divided into exurban and small town subareas because there are substantial differences between 
home purchasers in these two areas. As will be shown, they differ in reasons for moving, occupations, income, work locations, and commuting trip characteristics.

(Please note that only current residential locations can be accurately divided into exurban and small town categories. The analysis of former residences and job locations is based on zip-code zones which encompass both small town and exurban areas. Exurban and small town locations cannot be separated in that part of the analysis.)

WHO ARE THE EXURBAN HOME PURCHASERS?

The typical household buying an exurban home near Portland, Oregon, in 1987 was a family with children and two adult wage earners. They previously lived in a suburb of Portland. The primary wage earner holds a managerial, professional, or blue collar job while the secondary wage earner has a technical, sales, or clerical position. Both commute to the urban or suburban area. Their household income is in the $\$ 40,000-\$ 49,999$ range.

While this typical exurban household closely resembles an average suburban home buying household, what they are buying differs. The exurban home purchasers are looking for land, open space, quiet, and privacy which are not available in the city or suburbs. They are willing to commute more to obtain these rural amenities. In comparison, suburban home buyers are more interested in housing quality and quantity. 
Naturally this portrait of a typical exurban household does not fit all exurban households perfectly. The following tables and discussion provide more detailed information on exurban home purchasers as well as comparing them with their small town and suburban neighbors. Topics in this section are former residences, workforce participation, noncommuters, job location, and occupation and income.

\section{Former Residence}

As Table VIII shows about four out of five exurbanites made local moves with over half coming from Portland and its suburbs. Only a quarter of the exurban buyers already lived in the exurban/small town zone. Nearly the same proportions of small town and suburban home purchasers made local moves, but the majority of home purchasers in these areas already

TABLE VIII

PLACE OF FORMER RESIDENCE OF HOME PURCHASERS

BY RESIDENTIAL SUBAREAS

\begin{tabular}{|c|c|c|c|}
\hline & & Moved to & \\
\hline Moved from & Exurban & small Town & Suburban \\
\hline Local Area & & & \\
\hline Urban & $16 \%$ & $8 \%$ & $13 \%$ \\
\hline suburban & $36 \%$ & $15 \%$ & $55 \%$ \\
\hline Exurban/Small Town & $27 \%$ & $53 \%$ & $3 \%$ \\
\hline Total & $79 \%$ & $76 \%$ & $71 \%$ \\
\hline other Areas & & & \\
\hline other Oregon & $5 \%$ & $11 \%$ & $6 \%$ \\
\hline out-of-state & $16 \%$ & $13 \%$ & $24 \%$ \\
\hline Total & $21 \%$ & $24 \%$ & $30 \%$ \\
\hline & $n=248$ & $n=185$ & $n=433$ \\
\hline
\end{tabular}


lived in the zone in which they purchased their new home. In addition small towns attracted a greater proportion of households moving from other parts of oregon, while suburbs became home to more households from other states.

Table IX which is based on household's perceptions of their present and former neighborhoods confirm these

TABLE IX

HOME PURCHASERS' DESCRIPTIONS OF PRESENT AND FORMER NEIGHBORHOODS BY TYPES OF MOVE AND RESIDENTIAL SUBAREAS

Former-Present Neighborhood

Residential subarea Exurban Small Town Suburban

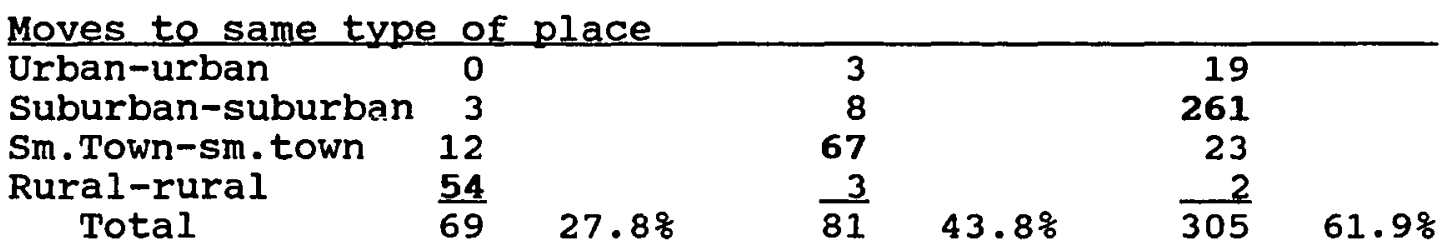

Moves to less urban place Urban-suburban 3 Urban-sm.town 7 Urban-rural $\quad 51$ Suburban-sm. town 7 Suburban-rural 76 Sm.Town-rural 21 Total 165

$\begin{array}{rrrrr} & 0 & & 70 & \\ & 22 & 10 & \\ & 8 & 4 & \\ & 25 & & 22 & \\ & 5 & & 8 & \\ 66.58 & \frac{5}{65} & 35.1 \% & -114 & 0 \\ & & & 23.18\end{array}$

Moves to more urban place Suburban-urban

Sm. Town-urban Sm. Town-suburban Rural-urban Rural-suburban Rural-sm.town Total

0
4
0
5
$\frac{5}{14}$

1

$\begin{array}{ll}1 & 2 \\ 0 & 1\end{array}$

5

$\frac{5}{14}$

$5.6 \%$

$248 \quad 99.98$

$185 \quad 100.0 \%$

$493100.0 \%$

All moves

Note: Bold type indicates households' descriptions of present neighborhoods agrees with study definition. 
findings. The exurban column shows that most exurban home purchasers moved from a more urban place. In contrast most suburban home buyers already lived in suburbs, and small town buyers came most often from small towns or rural areas.

\section{Workforce Participation}

Most of home-buying households include employed persons. Table $\mathrm{X}$ shows that exurban households have the lowest rate of being out of the workforce and the highest rate of having two adults in the workforce. Most of the households with no wage earners are retired although in a few cases unemployment is the cause. Small town home buyers have the highest rate of non-participation in the workforce. In part this is due to the large number of home sales in a retirement community in woodburn, but it also reflects the general popularity of small towns as places for retirement.

\section{TABLE X}

WORKFORCE PARTICIPATION OF HOME PURCHASERS

BY RESIDENTIAL SUBAREAS

No wage earners

One wage earner

Two wage earners
Exurban

$$
4.8 \%
$$

$32.7 \%$

$\frac{62.5 \%}{100.08}$

$n=251$
Small Town $20.6 \%$

$34.4 \%$

$\frac{45.0 \%}{100.0 \%}$

$n=189$
Suburban

$9.8 \%$

$38.6 \%$

$\frac{51.6 \%}{100.0 \%}$

$n=500$

One of the reasons that so many exurban households include two wage earners is that single working adults rarely purchase exurban homes. Table XI shows that exurban 
home purchasers are the least likely to be single working adults. Since the proportions of households with two or more adults but only one wage earner are nearly constant across areas, the dearth of single adult households in exurbia must be compensated for by more two-wage earner households. Note that the proportion of exurban households with two wage earners and children is the highest for all types and all areas. Nonetheless the proportion of working households with children is nearly the same in exurbs and small towns (64.0 percent and 63.3 percent, respectively) and only slightly lower (58.1 percent) in suburbs.

TABLE XI

FAMILY CHARACTERISTICS OF HOUSEHOLDS IN WORKFORCE BY RESIDENTIAL SUBAREAS

Exurban

Small Town

Suburban

Households with one adult

No children $3.3 \%$

With children $\quad 1.3 \%$

$6.0 \%$

$7.3 \%$

9.18

$3.5 \%$

Households with two or more adults

one wage earner

No children

with children

Two wage earners

No children

with children
$8.8 \%$

$20.9 \%$

$23.8 \%$

$41.8 \%$

99.98

$n=239$
$10.7 \%$

$19.3 \%$

$10.4 \%$

$19.7 \%$

Total
$22.4 \frac{8}{8}$

$34.8 \%$

$20.0 \%$

$36.7 \%$

$100.0 \%$

$99.9 \%$

$\mathrm{n}=150$

$n=451$

\section{Noncommuters}

Some of the wage earners from these households of movers do not fit the study's definition of commuter. That 
is, they do not travel to a fixed place of work at least once a week. Either they work at home, their work places are variable, or their travel to work is infrequent. About six percent of both primary and secondary workers from all areas belong in one of these classifications.

Home-based workers include daycare providers, consultants, owners of repair shops, farmers, and clerical workers. These home-based workers are clearly not the vanguard of a movement to electronic cottages. There are very few of them, even fewer telecommute, and most do work that has traditionally been done in homes.

Workers with variable workplaces include sales representatives, long distance truck drivers, and construction workers. Exurban areas seem especially attractive to construction workers with variable workplaces as seven of the 15 exurban primary wage earners who do not fit the definition of commuting hold these jobs. Sales representatives who serve territories ranging from the metropolitan area to several states seem to prefer suburban areas. Twelve of the 23 suburban noncommuting principal wage earners work in sales.

Finally, a few people live in the Portland region but work elsewhere. They are omitted from the commuting analysis either because they travel to work less than once a week or because their long commutes (for example, to Seattle, Washington, and Provo, Utah) would distort the 
analysis. All of those who do not fit the commuting definition are left out of the following discussion which focuses on commuters.

\section{Job Location}

Most of those who do commute did not change job locations when they moved as indicated in Table XII. This was anticipated since about three-fourths of ald moves were local. Smaller numbers changed jobs along with moving, as expected of movers from outside the region, or have changed jobs or entered the workforce between the time of the move and the completion of the survey. Secondary workers are more likely to have new jobs than primary wage earners. This is consistent with the theory that households select residential locations based on the primary wage earner's job location, and then the secondary wage earner chooses a job from that residential location (Singell and Lillydahl 1986).

TABLE XII

EFFECT OF MOVE ON COMMUTER'S JOB LOCATION BY TYPE OF EARNER AND RESIDENTIAL SUBAREAS

\begin{tabular}{|c|c|c|c|c|c|c|}
\hline \multirow[b]{2}{*}{ Location } & \multicolumn{3}{|c|}{ Primary Wage Earners } & \multicolumn{3}{|c|}{ Secondary Wage Earners } \\
\hline & Exurb & SmTown & Suburb & Exurb & SmTown & Suburb \\
\hline $\begin{array}{l}\text { Same location } \\
\text { Location changed }\end{array}$ & $d^{65 \%}$ & $68 \%$ & $64 \%$ & $58 \%$ & $50 \%$ & 618 \\
\hline $\begin{array}{l}\text { with move } \\
\text { Location changed }\end{array}$ & $a^{18 \%}$ & $12 \%$ & $23 \%$ & $14 \frac{2}{2}$ & $21 \%$ & 168 \\
\hline $\begin{array}{l}\text { since move } \\
\text { Not employed }\end{array}$ & $16 \%$ & $18 \%$ & $13 \%$ & $22 \frac{9}{2}$ & $17 \%$ & $19 \%$ \\
\hline before move & $1 \%$ & $1 \%$ & $0 \%$ & $4 \%$ & $10 \%$ & $3 \%$ \\
\hline & $n=221$ & $n=137$ & $n=430$ & $n=154$ & $\mathrm{n}=82$ & $\mathrm{n}=244$ \\
\hline
\end{tabular}


Exurban and suburban movers have similar patterns of job change rates while small town home buyers have different patterns. Small town principal wage earners are most likely to be at the same job location while small town secondary wagers are least likely to be at the same place. Also more of the small town secondary wage earners have entered the work force since their move.

Given that many exurbanites previously lived in the suburbs and have not changed jobs, their job locations should resemble those of suburbanites. Table XIII confirms that this is true. Seventy-seven percent of the exurban principal wage earners and 71 percent of the secondary wage earners commute to urban or suburban zones. More hold urban than suburban jobs. That makes exurbanites the most likely group to commute out of their residential zone. But about one-fourth of the exurbanites do work in the exurban/small

TABLE XIII

WORK LOCATIONS OF COMMUTERS BY TYPE OF EARNER AND RESIDENTIAL SUBAREAS

\begin{tabular}{lrrrrrrr} 
& \multicolumn{2}{c}{ Primary Wage Earners } & \multicolumn{3}{c}{ Secondary Wage Earners } \\
\cline { 2 - 4 } Job Zone & Exurb & SmTown & Suburb & Exurb & SmTown & Suburb \\
\hline Urban & $41 \%$ & $17 \%$ & $49 \%$ & $37 \%$ & $16 \%$ & $40 \%$ \\
Suburban & $36 \%$ & $33 \%$ & $48 \%$ & $34 \%$ & $25 \%$ & $58 \%$ \\
Exurban/Sm. Twn & $21 \%$ & $47 \%$ & $2 \%$ & $28 \%$ & $60 \%$ & $2 \%$ \\
Out-of-area & $3 \%$ & $3 \%$ & $1 \%$ & $2 \%$ & $0 \%$ & $0 \%$ \\
& $n=195$ & $n=118$ & $n=389$ & $n=135$ & $n=76$ & $n=216$
\end{tabular}


town zone where they live. That gives them somewhat lower rates of holding urban and suburban jobs than suburbanites who rarely commute out to exurban/small town jobs.

Although exurban and small town home buyers both live some distance from the urban core, they have very different patterns of job location. Unlike the exurbanites, almost half of the small town principal wage earners and 60 percent of the secondary earners work in the exurban/small town zone where they live. This group is least likely, by a wide margin, to commute to urban areas, although about one-third of the primary earners and one-fourth of the secondary earners commute to suburbs.

occupation and Income

Occupations are important in determining work and home locations as well as commuting characteristics. Occupations were classified following the abbreviated procedure recommended by the office of Federal statistical Policy and Standards (1980). The categories are:

1. Managerial and professional (Major Groups 10-34)

2. Technical, sales, and clerical (Major Groups 36-48)

3. Service (Major Groups 50-53 and 91)

4. Agriculture, forestry and fishing (Major Groups 5558)

5. High Skill Blue Collar (Major Groups 60-69)

6. Low Skill Blue Collar (Major Groups 71-87) 
The occupations of the commuting home purchasers are outlined in Table XIV. Once again exurban and suburban residents are similar with most principal wage earners holding managerial and professional or technical, sales, and clerical positions. A major difference is that exurban principal wage earners are twice as likely to be blue collar workers as suburban primary wage earners. In contrast, small town principal wage earners are less likely to hold managerial and professional positions and more likely to have low skill blue collar jobs.

TABLE XIV

OCCUPATIONS OF COMMUTERS BY TYPE OF EARNER AND RESIDENTIAL SUBAREAS

Classification Exurban Small Town Suburban Principal Wage Earners Management, Prof. Tech, Sales, clerical Service

\section{$42 \%$}

$18 \%$

$2 \%$

Ag, Forest, Fish

Hi Skill Blue Collar

Lo Skill Blue Collar Total

$\begin{array}{r}3 \% \\ 18 \% \\ 17 \% \\ \hline 100 \%\end{array}$

$\mathrm{n}=\mathbf{2 1 5}$

\begin{tabular}{rr}
$31 \%$ & $50 \%$ \\
$22 \%$ & $31 \%$ \\
$6 \%$ & $3 \%$ \\
$2 \%$ & $0 \%$ \\
$14 \%$ & $8 \%$ \\
$25 \%$ & $8 \%$ \\
\hline $100 \%$ & $\frac{8 \%}{100 \%}$ \\
$\mathrm{n}=136$ & $\mathrm{n}=423$
\end{tabular}

Secondary Wage Earners Management, Prof Tech, Sales, Clerical Service

Ag, Forest, Fish

Hi Skill Blue Collar

Lo Skill Blue Collar Total

\begin{tabular}{r}
$31 \%$ \\
$46 \%$ \\
$10 \%$ \\
$1 \%$ \\
$3 \%$ \\
$8 \%$ \\
\hline $99 \%$ \\
$\mathrm{n}=150$
\end{tabular}

$22 \%$

548

$20 \%$

$0 \%$

$4 \frac{8}{8}$

$\frac{1 \%}{101 \%}$

$\mathrm{n}=82$
$38 \%$

$50 \%$

$7 \%$

$0 \%$

$2 \%$

$\frac{48}{1018}$

$n=242$ 
Secondary wage earners from all residential areas are concentrated in technical, sales, and clerical positions followed by managerial and professional occupations. Here the exurbanites have rates in between those of suburban and small town secondary workers, except that more are low skill blue collar workers than elsewhere.

The differences in occupational structure of the areas combine with other factors such as the proportion of two wage earner families to produce various income patterns. In each residential area there are households at all income levels from less than $\$ 20,000$ annual income to over $\$ 100,000$. Median household income for both exurban and suburban home buyers is in the $\$ 40,000-\$ 49,999$ range while median household income for small town purchasers is in the $\$ 30,000-\$ 39,999$ range.

But another factor is also at work. Even within the same occupational classifications, small town residents tend to make less as illustrated in Table XV. For exampie small town households headed by technical, sales, and clerical workers are clustered at the low end of the income range while exurban and suburban households whose principal wage earners hold the same types of occupations have incomes more evenly distributed from low to very high.

\section{Summary}

In sum exurbanites resemble suburbanites more than
small town residents. Like suburbanites exurban home


TABLE XV

HOUSEHOLD INCOME BY OCCUPATION OF COMMUTING PRINCIPAL WAGE EARNER AND RESIDENTIAL SUBAREAS

Income Exurban Small Town suburban

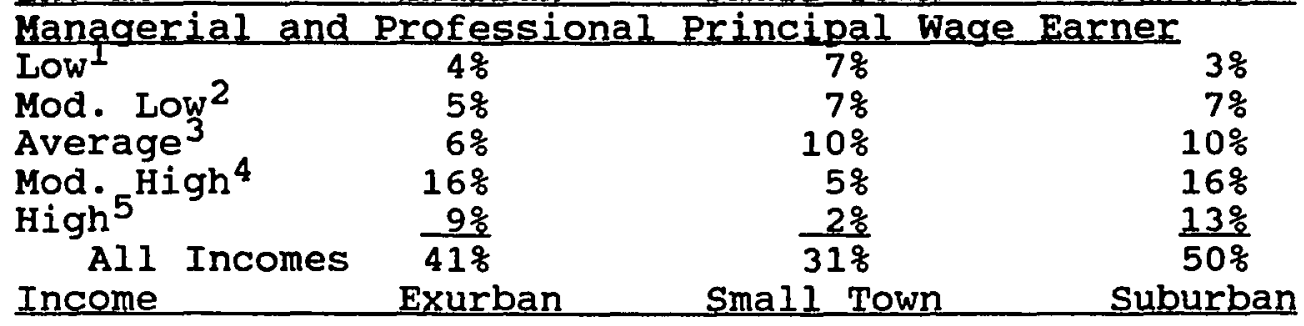

Technical, Sales and Clerical Principal Wage Earner

Low

Mod. Low

Average

Mod. High

4\%

$4 \%$

$12 \%$

7웅

$7 \%$

High

$5 \%$

$5 \%$

All Incomes $\frac{2 \%}{20 \%}$

$1 \%$

$6 \%$

$1 \%$

$\frac{1 \%}{22 \%}$

$6 \%$

$5 \%$

High Skill Blue Collar Principal Wage Earner

$\begin{array}{lrrr}\text { Low } & 4 \% & 6 \% & 2 \% \\ \text { Mod. Low } & 6 \% & 1 \% & 4 \% \\ \text { Average } & 4 \% & 3 \% & 2 \% \\ \text { Mod. High } & 3 \% & 3 \% & 1 \% \\ \text { High } & \frac{1 \%}{1} & 1 \% & \frac{0 \%}{8 \%} \\ \quad \text { All Incomes } & 18 \% & 14 \% & 8 \%\end{array}$

Low Skill Blue Collar Principal Wage Earner

\begin{tabular}{lccc} 
Low & $2 \%$ & $13 \%$ & $2 \%$ \\
Mod. Low & $7 \%$ & $6 \%$ & $4 \%$ \\
Average & $4 \%$ & $4 \%$ & $0 \%$ \\
Mod. High & $2 \%$ & $3 \%$ & $1 \%$ \\
High & $1 \%$ & $0 \%$ \\
\multicolumn{1}{c}{ All Incomes } & $17 \%$ & $\frac{0 \%}{2}$ &
\end{tabular}

Service Principal Wage Earners

$\begin{array}{llll}\text { All Incomes } & 2 \% & 6 \% & 3 \%\end{array}$

$\frac{\text { Agriculture, Forestry, and Fisheries Principal wage Earners }}{3 \%}$

$n=211 \quad n=136$ $n=411$

1 "Low" income includes the 159 households $(20.8$ percent of combined total) with household income under $\$ 30,000$

2 "Moderately Low" includes the 165 households (21.6 percent) with income in the $\$ 30,000-\$ 39,999$ range. 
TABLE XV

HOUSEHOLD INCOME BY OCCUPATION OF COMMUTING PRINCIPAL WAGE EARNER AND RESIDENTIAL SUBAREAS (continued)

3 "Average" includes the 151 households (19.8 percent) with incomes in the $\$ 40,000-\$ 49,999$ range.

4 "Moderately High" includes the 181 households $(23.7$ percent) with incomes between $\$ 50,000$ and $\$ 69,999$.

5 "High" includes the 109 households (14.2 percent) with incomes of $\$ 70,000$ or more.

purchasers often lived in the urban or suburban area before their move, have white collar jobs, work in urban and suburban places, and earn higher incomes. Unlike suburbanites and more like small town residents, exurbanites hold a substantial number of blue collar jobs. Also like small town residents, about one-fourth also lived in the exurban/small town zone prior to their move and some hold exurban/small town jobs. Differing from both groups, exurbarı households rarely have only one adult member and most often have two wage earners.

\section{WHY DID THEY MOVE?}

As will be documented more thoroughly later, the moves to exurbia usually require longer commutes. Why then are these household leaving suburbs and city to move to rural residential areas? What are the getting in exchange for more time spent commuting? 
Motivations For Moving

Many exurbanites are seeking larger lots, access to outdoor recreation, country views, privacy, and quiet that are not available in the urban/suburban regional center. Table XVI clearly shows this. (Note that all households including those who are retired or do not fit the definition of commuting are included here.) sixty-one percent of the exurban households gave owning large lots or acreage as one

TABLE XVI

THE THREE MOST IMPORTANT REASONS FOR MOVING OF HOME PURCHASERS BY RESIDENTIAL SUBAREAS

\begin{tabular}{|c|c|c|c|}
\hline Reason for moving & Exurban & $\begin{array}{l}\text { Small } \\
\text { Town }\end{array}$ & Suburban \\
\hline \multicolumn{4}{|l|}{ Job related } \\
\hline New job or transfer & $11 \frac{8}{6}$ & $11 \%$ & $19 \%$ \\
\hline $\begin{array}{l}\text { To be closer to work } \\
\text { To be farther from work }\end{array}$ & $13 \%$ & $15 \%$ & $19 \%$ \\
\hline \multicolumn{4}{|l|}{ Family/life cycle } \\
\hline Retirement & 5 安 & $16 \%$ & $7 \%$ \\
\hline Married, widowed, etc. & $3 \%$ & $11 \%$ & $11 \%$ \\
\hline Better for raising family & $27 \%$ & $25 \%$ & $28 \%$ \\
\hline other family/personal & $11 \%$ & $22 \%$ & $17 \%$ \\
\hline \multicolumn{4}{|l|}{ Housing related } \\
\hline Better quality house & $17 \%$ & $19 \%$ & $27 \%$ \\
\hline Different size house & $18 \%$ & $26 \%$ & $29 \%$ \\
\hline Less expensive house & $4 \%$ & $18 \%$ & $7 \%$ \\
\hline Own instead of rent & $36 \%$ & $43 \frac{\%}{8}$ & $46 \%$ \\
\hline \multicolumn{4}{|l|}{ Rural living } \\
\hline Large lot or acreage & $61 \%$ & $10 \%$ & $8 \%$ \\
\hline Live in more rural area & $50 \%$ & $17 \%$ & $9 \%$ \\
\hline \multirow{2}{*}{\multicolumn{4}{|c|}{$\begin{array}{l}\text { Urban living } \\
\text { Live in more urban area }\end{array}$}} \\
\hline & $1 \%$ & $4 \%$ & $4 \%$ \\
\hline \multicolumn{4}{|l|}{ Public services/costs } \\
\hline Better schools & $6 \%$ & $6 \%$ & $14 \frac{9}{8}$ \\
\hline Lower taxes & $4 \%$ & $6 \%$ & $4 \%$ \\
\hline \multirow{3}{*}{$\begin{array}{l}\text { Former neighborhood changed } \\
\text { All other responses }\end{array}$} & $11 \%$ & $15 \%$ & $16 \%$ \\
\hline & $12 \%$ & 218 & $15 \%$ \\
\hline & $n=254$ & $n=185$ & $n=503$ \\
\hline
\end{tabular}


of their three main reason for moving. Living in a more rural area was also important to half the exurban households. No reasons were so compelling for the small town and suburban purchasers. Instead a mix of traditional reasons for moving related to housing and family were most important for those groups. But housing and family reasons, especially owning instead of renting and having a better place to raise a family, were also important to many exurbanites.

Job and commuting reasons were only of moderate importance for moving to any residential subarea. Job change would of course be a factor in many of the interstate moves, but 71-79 percent of the moves were local. Other surveys of households making local moves also have found that housing needs and family characteristics are the primary reasons for moving. Job change or being closer to work are seldom mentioned as the reasons for moving within a metropolitan area even when the household does in fact move closer to work (Clark and Burt 1980).

Although Tiebout (1956) asserts that people choose residential location that matches their preferences for public goods and services, few people actually cite public services or costs as a main reason for moving. Better schools or lower taxes were a main reason for moving for only 4-6 percent of the households, except that 14 percent of the suburban buyers were seeking better schools. 
When it came to choosing a particular neighborhood the motivations of all movers are more alike as Table XVII shows. In all residential areas the households selected finding the best or most affordable house and the looks/design of the neighborhood as their top reasons for neighborhood selection. All groups also ranked convenience to job and good schools as the third and fourth most important reasons for selecting a neighborhood. Note that exurbanites have the lowest rate of specifying convenience

TABLE XVII

THE THREE MOST IMPORTANT REASONS FOR CHOOSING A PARTICULAR NEIGHBORHOOD BY RESIDENTIAL SUBAREAS

\begin{tabular}{|c|c|c|c|}
\hline Reasons for selecting neighborhood & Exurb & $\begin{array}{l}\text { Smal1 } \\
\text { Town }\end{array}$ & Subu: \\
\hline \multicolumn{4}{|l|}{ Housing and neighborhood attributes } \\
\hline Best/most affordable house here & $54 \%$ & 618 & 4 \\
\hline Looks/design of neighborhood & $40 \%$ & $36 \%$ & \\
\hline Good schools & $27 \%$ & $25 \%$ & \\
\hline Public services & $1 \%$ & $5 \%$ & \\
\hline Cost factors* & $9 \%$ & $7 \%$ & \\
\hline \multicolumn{4}{|l|}{ Jobs } \\
\hline Convenient to job & $28 \%$ & $32 \%$ & \\
\hline \multicolumn{4}{|l|}{ People } \\
\hline Close to friends/relatives & $21 \%$ & $31 \%$ & \\
\hline People here like us & $13 \%$ & $23 \%$ & \\
\hline \multicolumn{4}{|l|}{ Accessibility } \\
\hline Access to freeways/highways & $27 \%$ & $17 \%$ & \\
\hline Availability of public transit & $1 \frac{8}{8}$ & $3 \%$ & \\
\hline Close to parks/recreation & $10 \%$ & $16 \%$ & \\
\hline Near shopping & $7 \%$ & $11 \%$ & \\
\hline \multicolumn{4}{|l|}{ Rural attributes* } \\
\hline Rural environment* & $11 \%$ & $2 \%$ & \\
\hline To own land* & $10 \%$ & oq & \\
\hline \multirow{3}{*}{$\begin{array}{l}\text { Quiet, secluded or private* } \\
\text { All other* }\end{array}$} & $7 \frac{9}{6}$ & $2 \frac{8}{8}$ & \\
\hline & $11 \%$ & $15 \%$ & \\
\hline & $\mathrm{n}=252$ & $n=185$ & $n=5$ \\
\hline
\end{tabular}

* indicates other reason added by some households. 
to job as a major determinant of neighborhood selection. Yet they place more importance on access to freeways and highways than small town residents do.

Many exurbanites found, however, that the list of housing and neighborhood attributes and accessibility factors that was provided did not adequately describe their reasons for selecting a rural neighborhood. About 28 percent of the exurban purchasers added reasons such as being near forested land or open space, owning acreage, raising wine grapes, having horses, or wanting quiet and privacy. Added to the strong preference for rural living previously noted as reasons for moving, this strengthens the argument that rural amenities unavailable in small towns, suburbs, or cities are what draw many people to exurban places.

\section{Lot sizes}

Ownership of large lots or acreage is one of the rural attributes desired by many exurbanites that is easy to quantify. Table XVIII shows that not only did exurbanites want large lots, they were able to buy them. Eighty-five percent of the exurban buyers bought lots of at least one acre with over one-third buying lots of five or more acres. In contrast, 88.6 percent of small town buyers and 94.8 percent of suburbanites bought lots under one acre with most buying lots of less than one-fourth acre (about 11,000 square feet). Since current land use regulations generally 
TABLE XVIII

LOT SIZES PURCHASED BY RESIDENTIAL SUBAREAS

\begin{tabular}{lrrrrrr} 
Lot sizes & \multicolumn{2}{c}{ Exurban } & \multicolumn{2}{c}{ Small Town } & \multicolumn{2}{c}{ Suburban } \\
(in acres) & No. Percent & No. & Percent & No. Percent \\
\hline 0 to .24 & 7 & $29.9 \%$ & 95 & $63.3 \%$ & 263 & $65.1 \%$ \\
:25 to .99 & 29 & $11.8 \%$ & 38 & $25.3 \%$ & 120 & $29.7 \%$ \\
1 to 4.99 & 121 & 49.4 & 14 & $9.3 \%$ & 18 & $4.5 \%$ \\
5 or more & $\frac{88}{245}$ & $\frac{35.9 \%}{100.0 \%}$ & $\frac{3}{150}$ & $\frac{2.0 \%}{99.9 \%}$ & $\frac{3}{404}$ & $\frac{0.7 \%}{100.0 \%}$ \\
$\quad$ Total & & & & & &
\end{tabular}

require exurban lots to be five or more acres in size, the large number of smaller lots is indicative of the large amount of subdividing which was done prior to statewide land use planning.

While exurbanites may want large lots, few seem to be buying land for farm or forestry purposes. Only 16 percent of the rural parcels had farm property tax deferrals or were classified as agricultural or forestry lands.

\section{Summary}

Exurbanites are a diverse group in terms of occupation and income but are generally united in their desires for space and rural amenities. Many were seeking a better life. One respondent states, "We hated living in a suburban neighborhood. The houses are crammed together with little or no privacy. We were willing to give up convenient access to Portland to get out of it." Another says, "We moved from a wealthy suburb in Washington state to a more peaceful-less stressful--environment in oregon. [We] wanted land to grow organic produce and maintain a woodland element." Even 
one person who has changed jobs since moving and now has a long commute says, "I do not want to move closer to my job because I very much like rural living."

\section{HOW DID MOVING AFFECT COMMUTING?}

One way exurban home purchasers paid for the desired rural attributes was with longer commutes, though some find positive benefits to commuting through the countryside. This section first compares the commutes and work schedules of exurban home buyers with those of home-buyers from small towns and suburbs and then compares present work trips with trips before their moves.

\section{Commuting Trip Characteristics}

Trip Length. More exurbanites have long commutes, whether measured in time or distance, than members of the other groups. Figure 3 illustrates this using miles per one-way trip. This figure compares the distribution of trip lengths of commuters from each residential area. Note that the distributions for primary and secondary wage earners from each residential subarea are closely related even though secondary wage earners tend to travel shorter distances which produces more peaked distributions

The fairly flat exurban distributions, with their peaks at 16-20 and 11-15 miles for primary and secondary wage earners respectively, indicate that few exurbanites commute short distances and many travel longer distances than the 


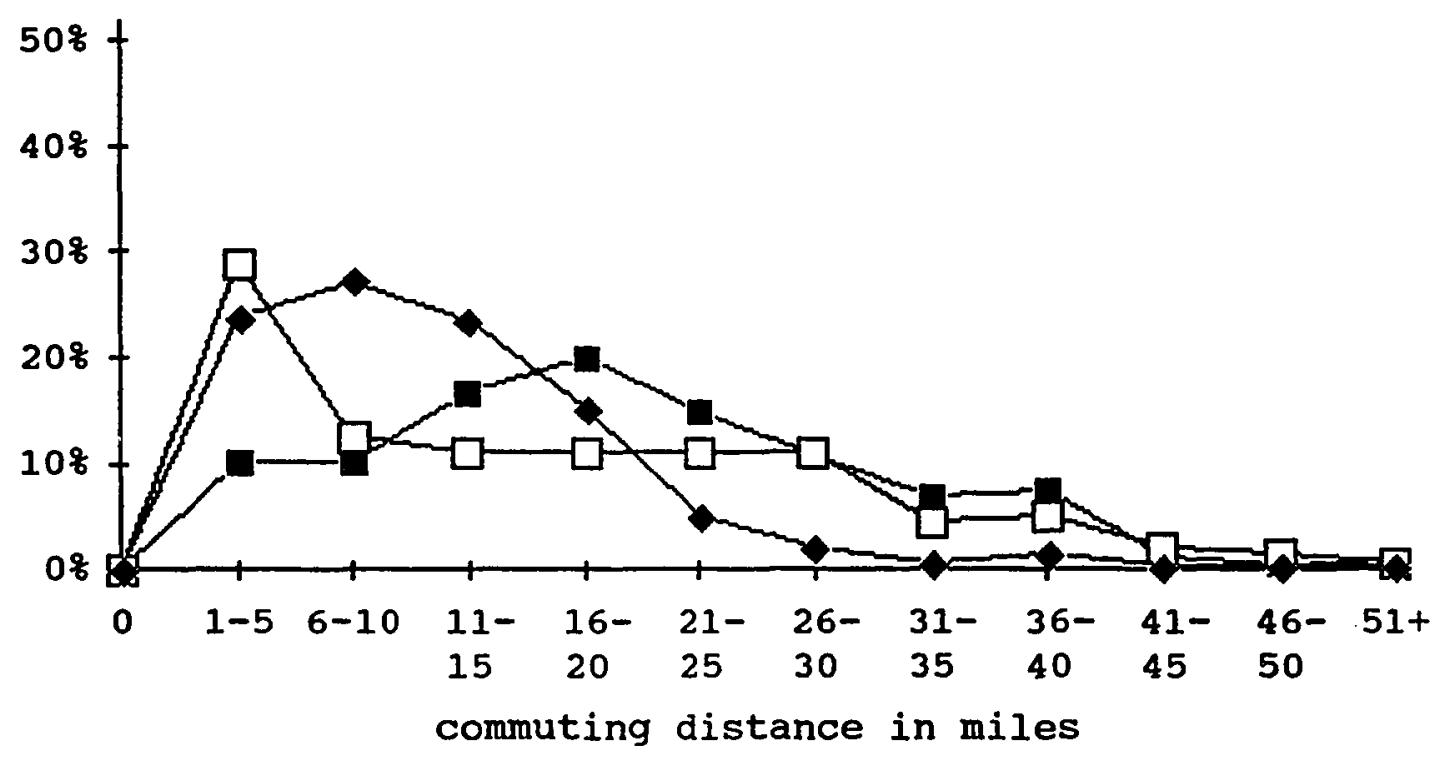

Secondary wage Earners

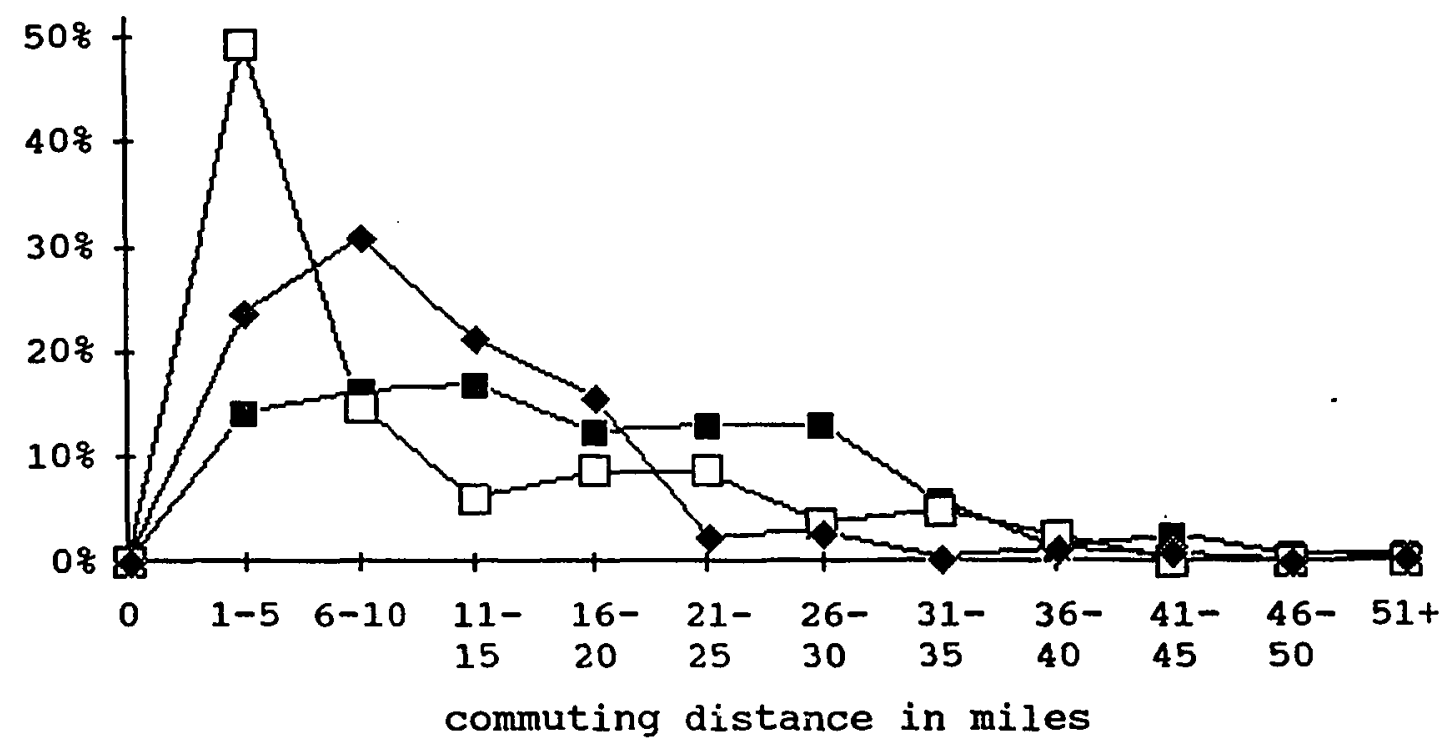

Exurban $\square$ Small Town $\downarrow$ Suburban

Figure 3. Relative frequency of commuting distances by residential subarea and type of wage earner. 
average commuters from the other areas. In sharp contrast, small town buyers have the most peaked distributions of trip length with 29 percent of the principal wage earners and 51 percent of the secondary earners commuting five miles or less. Most suburban home purchasers travel 20 miles or less to work with fairly high frequencies in each interval between zero and 20 miles.

Trip lengths measured in time follow a similar pattern. Table XIX summarizes the trip lengths, measured in both miles and minutes. Although exurban principal wage earners do not have the longest maximum trips, their averages are higher than elsewhere. Also a few secondary wage earners

TABLE XIX

COMMUTING TIMES AND DISTANCES BY TYPE OF WAGE EARNER AND RESIDENTIAL SUBAREAS

\begin{tabular}{|c|c|c|c|c|c|c|}
\hline \multirow{3}{*}{\multicolumn{2}{|c|}{$\begin{array}{l}\text { Residential Location } \\
\text { Principal Wage Earners } \\
\text { Exurban Minutes }\end{array}$}} & \multirow{2}{*}{ Min } & \multirow[t]{2}{*}{$\operatorname{Max}$} & \multirow[t]{2}{*}{ Median } & \multicolumn{2}{|c|}{ Mean St.Dev } \\
\hline & & & & & & \\
\hline & & $\begin{array}{l}2 \\
1\end{array}$ & $\begin{array}{l}80 \\
60\end{array}$ & $\begin{array}{l}30 \\
20\end{array}$ & $\begin{array}{l}29.7 \\
20.2\end{array}$ & $\begin{array}{l}14.8 \\
11.1\end{array}$ \\
\hline $\begin{array}{l}\text { Small Town } \\
(n=135)\end{array}$ & $\begin{array}{l}\text { Minutes } \\
\text { Miles }\end{array}$ & $\begin{array}{l}2 \\
1\end{array}$ & $\begin{array}{l}90 \\
75\end{array}$ & $\begin{array}{l}20 \\
15\end{array}$ & $\begin{array}{l}23.6 \\
16.7\end{array}$ & $\begin{array}{l}16.4 \\
13.6\end{array}$ \\
\hline $\begin{array}{l}\text { Suburban } \\
(n=424)\end{array}$ & $\begin{array}{l}\text { Minutes } \\
\text { Miles }\end{array}$ & $\begin{array}{l}2 \\
1\end{array}$ & $\begin{array}{l}50 \\
47\end{array}$ & $\begin{array}{l}20 \\
10\end{array}$ & $\begin{array}{l}20.6 \\
11.9\end{array}$ & $\begin{array}{r}10.2 \\
7.9\end{array}$ \\
\hline Secondary & ge Earner & & & & & \\
\hline $\begin{array}{l}\text { Exurban } \\
(n=152)\end{array}$ & $\begin{array}{c}\text { Minutes } \\
\text { Miles }\end{array}$ & $\begin{array}{l}2 \\
1\end{array}$ & $\begin{array}{r}105 \\
95\end{array}$ & $\begin{array}{l}27 \\
16\end{array}$ & $\begin{array}{l}27.7 \\
18.4\end{array}$ & $\begin{array}{l}16.0 \\
12.6\end{array}$ \\
\hline $\begin{array}{l}\text { Small Town } \\
(n=81)\end{array}$ & $\begin{array}{l}\text { Minutes } \\
\text { Miles }\end{array}$ & $\begin{array}{l}1 \\
1\end{array}$ & $\begin{array}{l}60 \\
40\end{array}$ & $\begin{array}{r}10 \\
5\end{array}$ & $\begin{array}{l}16.7 \\
11.2\end{array}$ & $\begin{array}{l}14.5 \\
11.2\end{array}$ \\
\hline $\begin{array}{l}\text { Suburban } \\
(n=243)\end{array}$ & $\begin{array}{r}\text { Minutes } \\
\text { Miles }\end{array}$ & $\begin{array}{l}2 \\
1\end{array}$ & $\begin{array}{l}65 \\
66\end{array}$ & $\begin{array}{l}20 \\
10\end{array}$ & $\begin{array}{l}20.2 \\
11.5\end{array}$ & $\begin{array}{r}11.3 \\
8.0\end{array}$ \\
\hline
\end{tabular}


have longer trips than principal wage earners, but the averages are always less in each residential subarea. Exurban trips show more variability than suburban trips, but not always more than small town trips.

The means for suburban residents are close to those reported by Gordon, Kumar and Richardson (1989) for morning rush hour trips by private vehicle in 1983. They found mean trips of 21.9 minutes or 12.1 miles for non-central city residents of metropolitan areas with 500,000-999,999 residents and mean trips of 21.1 minutes or 10.6 miles for similar residents in areas with 1-3 million residents. Thus Portland's suburban home buyers have trip lengths much like suburban residents throughout the United states. (The Gordon, Kumar and Richardson figures would include exurban residents of metropolitan counties but their influence is certainly overwhelmed by the more numerous suburbanites.)

Mode. Nearly all the commuters regardless of residential area drive alone to work as demonstrated in Table XX. Carpooling is the second most common mode followed by use of public transit. It should be noted that public transit is not available in many of the small towns and in much of the exurban area. Even when it is available it may not be convenient to use for work trips, as a number of respondents pointed out. A few workers use other modes such as walking or bicycling. 
TABLE XX

MODE OF TRAVEL TO WORK BY TYPE OF WAGE EARNER AND RESIDENTIAL SUBAREAS

\begin{tabular}{lrrrrrrr} 
& \multicolumn{2}{c}{ Primary Wage Earners } & \multicolumn{3}{c}{ Secondary Wage Earners } \\
\cline { 3 - 5 } Mode & Exurb & SmTown & Suburb & & Exurb & SmTown & Suburb \\
Drives alone & $91.9 \%$ & $89.8 \%$ & $88.3 \%$ & $92.8 \%$ & $87.8 \%$ & $88.9 \%$ \\
Carpools & $5.9 \%$ & $8.8 \%$ & $5.6 \%$ & $6.5 \%$ & $7.3 \%$ & $8.2 \%$ \\
Rides bus & $1.4 \%$ & $0.7 \%$ & $4.2 \%$ & $0.6 \%$ & $1.2 \%$ & $2.0 \%$ \\
Other & $0.9 \%$ & $0.7 \%$ & $1.9 \%$ & $0.0 \%$ & $3.7 \%$ & $0.8 \%$ \\
& & & & & & \\
& $n=221$ & $n=137$ & $n=430$ & $n=154$ & $n=82$ & $n=244$
\end{tabular}

stops. Driving alone makes it easy to make stops on the way to and from work as most commuters do. The types of stops made are outlined in Table XXI. Exurban residents are most likely to make stops, especially for personal business and shopping. Since they are less likely to live near banks, grocery stores, and other commercial activities, stopping on work trips seems very reasonable. Small town residents are the least likely to make stops perhaps because of the short lengths of their trips.

Secondary wage earners make stops more frequently than primary wage earners especially for doing personal business, shopping, transporting children, and visiting. since secondary wage earners are mostly female and more work parttime, these stops probably reflect their larger share of household responsibilities.

Work Schedules and Commuting. It was hypothesized that exurbanites would use flextime, working at home, and other scheduling innovations to help manage their commutes and to 
TABLE XXI

STOPS MADE ON WAY TO AND FROM WORK BY TYPE OF WAGE EARNER AND RESIDENTIAL SUBAREAS

\begin{tabular}{|c|c|c|c|}
\hline \multicolumn{4}{|c|}{ Principal Wage Earners } \\
\hline Purpose & Exurban & Sm. Town & Suburban \\
\hline Personal Business & $55 \%$ & $44 \%$ & $49 \%$ \\
\hline $\begin{array}{l}\text { Shop } \\
\text { Pick up or drop off family }\end{array}$ & $42 \%$ & $31 \%$ & $35 \%$ \\
\hline members at daycare/school & $18 \%$ & $13 \%$ & $17 \%$ \\
\hline Eat at restaurant & $17 \%$ & $11 \%$ & $18 \%$ \\
\hline Visit friends or relatives & $14 \%$ & $10 \%$ & $8 \%$ \\
\hline Recreation & $11 \%$ & $7 \%$ & $13 \%$ \\
\hline Other & $11 \frac{8}{6}$ & $8 \%$ & $6 \%$ \\
\hline Makes no stops & $23 \%$ & $31 \%$ & $34 \%$ \\
\hline & $n=218$ & $n=135$ & $n=428$ \\
\hline \multicolumn{4}{|c|}{ Secondary Wage Earners } \\
\hline Purpose & Exurban & Sm. Town & Suburban \\
\hline Personal Business & $70 \%$ & $45 \%$ & $62 \%$ \\
\hline Shop & $74 \frac{9}{6}$ & $48 \%$ & $56 \%$ \\
\hline Pick up or drop off family & & & \\
\hline members at daycare/school & $36 \%$ & $34 \%$ & $35 \%$ \\
\hline Eat at restaurant & $21 \%$ & $11 \%$ & $14 \%$ \\
\hline Visit friends or relatives & $28 \%$ & $19 \%$ & $10 \%$ \\
\hline Recreation & $10 \%$ & $4 \%$ & $10 \%$ \\
\hline Other & $3 \%$ & $8 \%$ & $6 \%$ \\
\hline Makes no stops & $11 \%$ & $24 \%$ & $16 \%$ \\
\hline & $n=151$ & $\mathrm{n}=80$ & $n=244$ \\
\hline
\end{tabular}

enable them to live farther from work. Tables XXII and XXIII indicate that exurbanites do not differ substantially from suburbanites in use of these trip management strategies. The major difference between the two tables is that secondary wage earners in the second table have more part-time jobs. This reduces both their work hours and the number of days they commute each week. 
TABLE XXII

WORK SCHEDULES OF COMMUTING PRINCIPAL WAGE EARNERS

BY RESIDENTIAL SUBAREAS

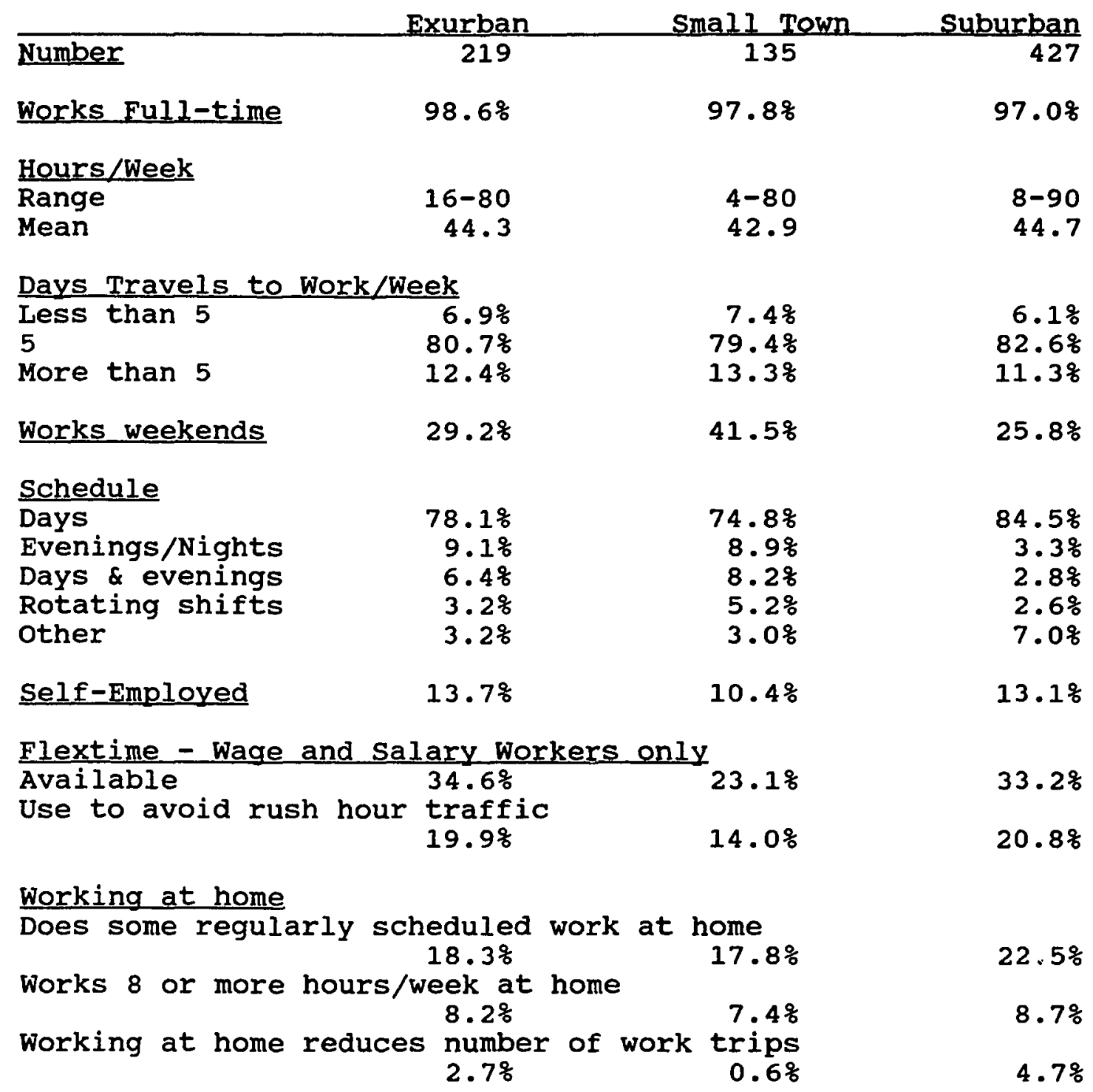


TABLE XXIII

WORK SCHEDULES OF COMMUTING SECONDARY WAGE EARNERS BY RESIDENTIAL SUBAREAS

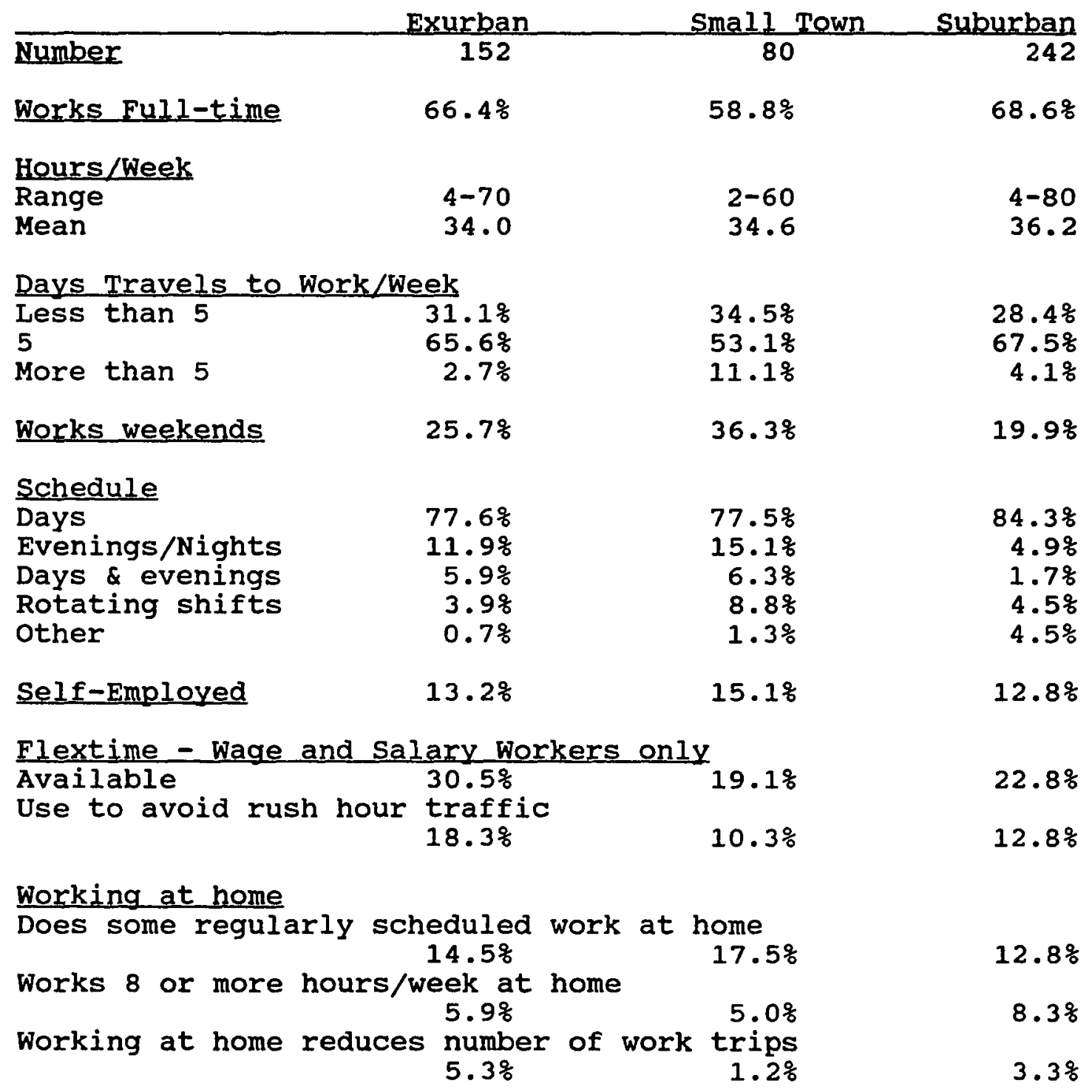


In 1985 about 84 percent of the full-time members of the workforce in the U.S. worked regular daytime shifts (Horvarth 1986). Suburbanites match this rate while both exurban and small town residents work more evening and night shifts. Exurban rates of working rotating or other shifts and working on weekends are in between those of suburbanites and small town residents.

Flextime can be an important tool for avoiding peak hour traffic. In 198512.3 percent of the wage and salary workers reported that they had flextime schedules (Mellor 1986). All groups of commuters in this study report much higher rates of flextime availability. Over half of those having flextime also report using it to avoid some or all of rush hour traffic. Some exurbanites and small town residents who do not use flextime to avoid traffic commented that there is no rush hour traffic where they live and work. Although not reported in Tables XXII and XXIII, selfemployed persons are even more likely to use flextime to avoid traffic with rates of use ranging from 33 to 45 percent. Managers and professionals have the highest rates of flextime use followed by technical, sales, and clerical workers for primary wage earners and service workers for secondary wage earners.

While Tables XXII and XXIII show that 14.5 to 22.5 percent of the commuters do some regularly scheduled work for their principal employer at home, few use working at 
home to reduce the number of trips they make to work each week. Most of the working at home would best be described as bringing work home. Few are scheduling regular days to work at home. The few who report less trips to work are managerial and professional or technical, sales, and clerical workers.

These working at home rates cannot be compared with rates from other studies because of different definitions. Some of the people who do not fit the study's definition of commuters, such as sales representatives and consultants, also do work at home. They are included in estimates of working at home in other studies. This study did not obtain enough information on home-based workers to make accurate comparisons.

\section{Changes in Commuting Trips}

Over half the exurban home purchasers report having longer work trips because of their move, as shown in Tables $\mathrm{XXIV}$ and XXV. Small town and suburban home purchasers give more mixed responses with some having longer trips, some shorter, and some the same length. Exurban home buyers are also more likely than the others to report faster speeds and more scenic drives. All groups report little change in trips per week, transit use, carpooling, stops, and road conditions and give mixed responses on congestion.

Figure 4, based on reported mileage before and after the move, confirms that trips of exurban home buyers became 
TABLE XXIV

COMPARISON OF PRESENT AND FORMER WORK TRIPS

OF COMMUTING PRINCIPAL WAGE EARNERS

BY RESIDENTIAL SUBAREAS

\begin{tabular}{lcccc} 
& \multicolumn{3}{c}{ Exurban Residents $(\mathrm{n}=209)$} \\
Comparison & More & Less & Same & Don't know/ \\
Nonswer
\end{tabular}

\begin{tabular}{lcccc} 
& \multicolumn{3}{c}{ Suburban Residents $(\mathrm{n}=426)$} \\
Comparison & More & Less & Same & Don't know/ \\
answer
\end{tabular}


TABLE XXV

COMPARISON OF PRESENT AND FORMER WORK TRIPS OF COMMUTING SECONDARY WAGE EARNERS

BY RESIDENTIAL SUBAREA

\begin{tabular}{|c|c|c|c|c|}
\hline & Exur & $n$ Res & its 1 & 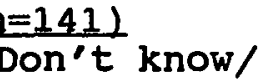 \\
\hline Comparison & More & Less & Same & No answer \\
\hline Miles & $63 \%$ & $23 \%$ & $14 \%$ & $0 q$ \\
\hline Minutes & $56 \%$ & $22 \%$ & $21 \%$ & 08 \\
\hline Trips/Week & $7 \%$ & $13 \%$ & $78 \%$ & 28 \\
\hline Transit Use & $3 \%$ & $9 \%$ & $72 \%$ & $16 \%$ \\
\hline Carpooling & 68 & $10 \%$ & $75 \%$ & $9 \%$ \\
\hline Stops enroute & 198 & $14 \%$ & $66 \%$ & $0 \%$ \\
\hline Congestion & $18 \%$ & $49 \%$ & $33 \%$ & $0 \%$ \\
\hline Speed & $53 \%$ & $14 \%$ & $33 \%$ & $1 \%$ \\
\hline & Better & Worse & Same & Don't know \\
\hline $\begin{array}{l}\text { Road conditions } \\
\text { Scenery }\end{array}$ & $\begin{array}{l}19 \% \\
68 \%\end{array}$ & $\begin{array}{r}26 \% \\
2 \%\end{array}$ & $\begin{array}{l}55 \% \\
29 \%\end{array}$ & $\begin{array}{l}0 \% \\
1 \%\end{array}$ \\
\hline & Smal1 & own Re & dents & $(n=69)$ \\
\hline Comparison & More & Less & same & $\begin{array}{l}\text { Don't know/ } \\
\text { No answer }\end{array}$ \\
\hline Miles & $34 \%$ & $40 \%$ & 248 & $1 \%$ \\
\hline Minutes & $35 \%$ & $39 \%$ & $25 \%$ & $1 \%$ \\
\hline Trips/Week & $9 \%$ & $10 \%$ & $78 \%$ & $3 \%$ \\
\hline Transit Use & $1 \%$ & $6 \%$ & $74 \%$ & $19 \%$ \\
\hline Carpooling & $4 \%$ & $7 \%$ & $68 \%$ & $20 \%$ \\
\hline Stops enroute & $12 \%$ & $13 \%$ & $72 \%$ & $3 \%$ \\
\hline Congestion & $19 \%$ & $33 \%$ & $47 \%$ & $1 \%$ \\
\hline Speed & $30 \%$ & $14 \%$ & $53 \%$ & $3 \frac{8}{6}$ \\
\hline & Better & Worse & Same & Don't know \\
\hline Road conditions & $23 \%$ & $6 \%$ & $70 \%$ & $1 \%$ \\
\hline Scenery & $25 \%$ & $12 \%$ & $63 \%$ & $1 \%$ \\
\hline & Subu & 1 Res & nts & $=2281$ \\
\hline & & & & Don't know/ \\
\hline Comparison & More & Less & Same & No answer \\
\hline Miles & $45 \%$ & $33 \%$ & $22 \%$ & $1 \%$ \\
\hline Minutes & $42 \%$ & $32 \%$ & $25 \%$ & $1 \%$ \\
\hline Trips/Week & $8 \%$ & $10 \%$ & $81 \%$ & $1 \%$ \\
\hline Transit Use & $2 \%$ & $6 \%$ & $78 \%$ & $14 \%$ \\
\hline Carpooling & 58 & $7 \%$ & $75 \%$ & $14 \%$ \\
\hline Stops enroute & $19 \%$ & $11 \%$ & $67 \%$ & $4 \%$ \\
\hline Congestion & $30 \%$ & $32 \%$ & $36 \%$ & $1 \%$ \\
\hline Speed & 328 & $23 \%$ & $43 \%$ & $2 \%$ \\
\hline & Better & Worse & Same & on't kno \\
\hline conditions & $26 \%$ & $13 \%$ & $58 \%$ & $4 \frac{8}{8}$ \\
\hline & 35 के & $8 \%$ & $54 \%$ & $3 \%$ \\
\hline
\end{tabular}


Principal Wage Earners

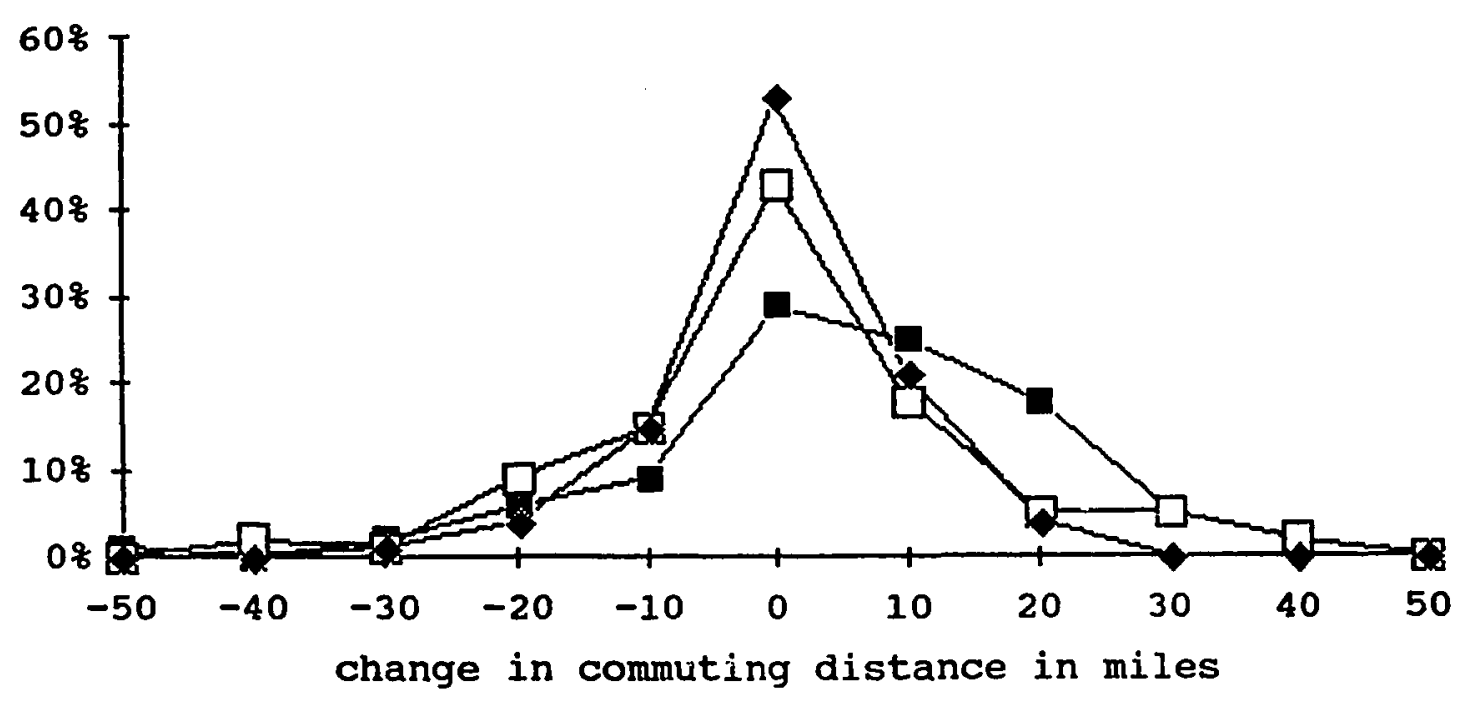

Secondary Wage Earners

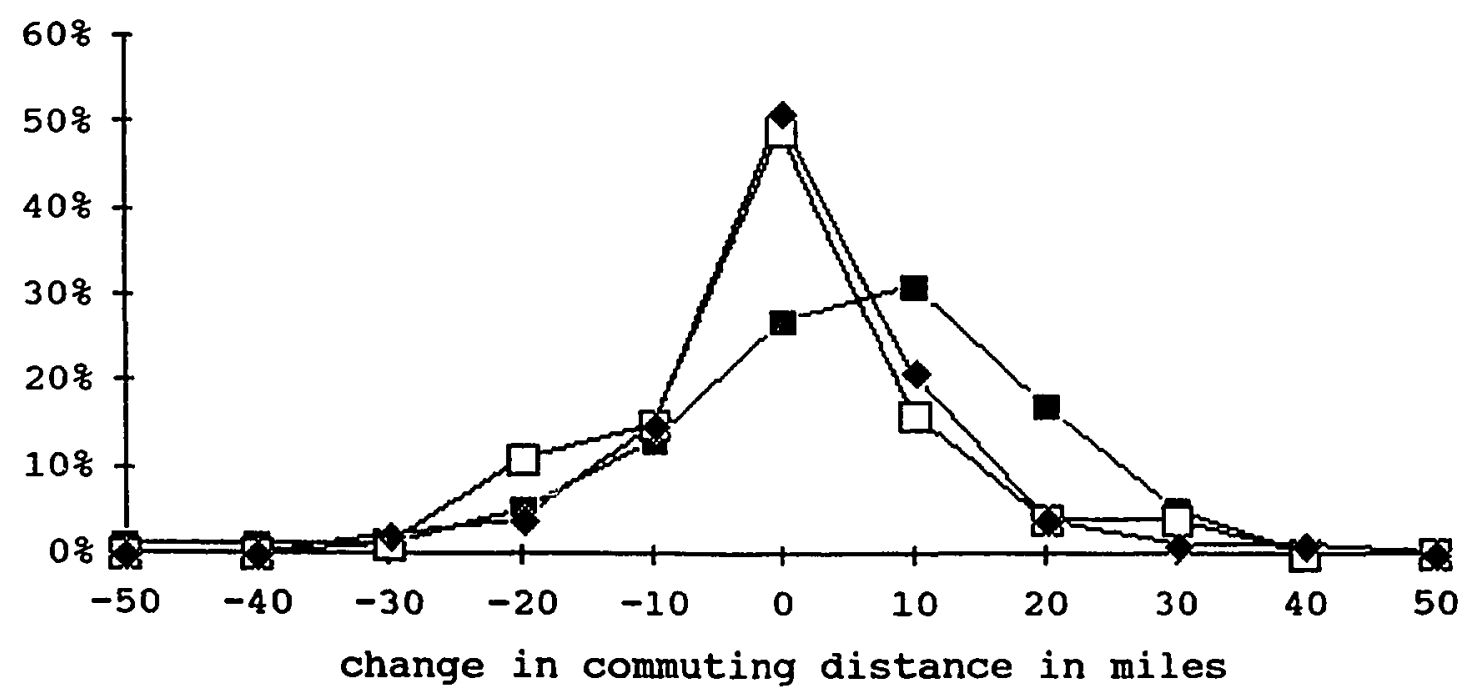

Exurban $\square$ Small Town Suburban

Figure 4. Relative frequency of change in commuting distances by residential subarea and type of wage earner. 
longer. Exurban commuters have skewed trip change distributions because many make longer trips. The secondary wage earners especially have longer trips with more reporting trip changes of 5 to 15 extra miles than any other category. On the other hand, small town and suburban commuters have symmetric distributions with most trips changing by less than five miles. Only a few of these commuters have substantially longer or shorter trips.

To help compensate for longer trip lengths about half of the rural residents report faster speeds of travel. Table XXVI shows the exurbanites do have faster average speeds than other groups and that their moves increased average speed more.

\section{TABLE XXVI}

COMMUTERS' MEAN SPEEDS OF TRAVEL BY TYPE OF WAGE EARNER AND RESIDENTIAL SUBAREAS

\begin{tabular}{|c|c|c|c|c|c|c|}
\hline \multirow[b]{2}{*}{ Speed $(\mathrm{mph})$} & \multicolumn{3}{|c|}{ Primary Wage Earners } & \multicolumn{3}{|c|}{ Secondary Wage Earners } \\
\hline & Exurb & Sm.Twn & Subu-b & Exurb & Sm.Twn & Suburb \\
\hline Present & 40.2 & 38.2 & 33.8 & 38.9 & 36.9 & 33.3 \\
\hline Former & 35.7 & 35.9 & 31.9 & 35.4 & 33.5 & 32.3 \\
\hline Change & 4.5 & 2.3 & 1.9 & 3.5 & 3.4 & 1.0 \\
\hline & $n=199$ & $n=126$ & $n=424$ & $n=129$ & $n=68$ & $n=205$ \\
\hline
\end{tabular}

Though the suburban speeds are the slowest, they are faster than those reported by Gordon, Kumar and Richardson (1989). They report 1983 work trip speeds during morning rush hour of 29.4 miles per hour for non-central city residents of metropolitan area with 500,000-999,999 residents and 28.2 miles per hour for similar trips in areas 
with 1-3 million residents. Apparently congestion is less of a problem in Portland than in many other cities.

About two-thirds of the exurban home buyers also find their trips more scenic while members of other groups tend to find the quality of scenery unchanged. For some exurban residents this scenic drive is an important part of what they gain in exchange for a longer arive to work. One commented, "Travel to work offers peaceful and serene countryside." Another states, "The principal wage earner likes the relaxing drive home through the countryside."

\section{Summary}

Thus moving to exurban areas often results in longer commutes in comparison both with their previous trips and with their suburban and small town neighbors. These trips may be faster and more scenic, but they still take more time than trips of suburban and small town resident.

The exurban home purchasers are aware of the trade-offs they are making. One states, "The quality of life in our rural setting (lower crime rate, privacy, clean air and quiet) is worth the additional commute time." Another says, "You couldn't pay me to live where I work [in Portland]!"

Some do have problems with or regrets about these tradeoffs. One states, "In some ways our 'quality of life' has decreased [due to recreational noise from dirt bikes and gunfire and other population pressures] and, at many times, we wonder if our long commute to work is really worth our 
rural environment." Some have found the commutes unbearable and have changed jobs. Others changed work locations after moving and now find their commutes questionably long. But in general, exurbanites seem pleased with their moves to rural areas.

\section{EXURBAN HOUSEHOLD TYPES}

The diversity of exurbanites leaves one wondering if there might be identifiable groups with different commuting patterns and household and job characteristics. k-means cluster analysis was used to tackle this question. only households with commuting principal wage earners were included in the analysis. Four clusters were identified using the variables listed in Table XXVII. Twenty-four percent of the households are in the Affluent cluster, 28 percent Child-Raising, 31 percent Economy-Minded, and 17 percent Long-Distance-Commuting.

Affluents are the stereotypical exurbanites with aboveaverage incomes, managerial and professional occupations, few children, large and expensive homes, and strong desires to own land and to live in a rural area. The child-Raising households have two or more children and generally two wage earners with short commutes and high rates of holding exurban/small town jobs. The Economy-Minded have low to moderate incomes and few children, buy the smallest and least expensive houses, and were strongly motivated by the 
TABLE XXVII

DEFINITION OF VARIABLES USED IN K-MEANS CLUSTER ANALYSIS

\begin{tabular}{|c|c|}
\hline Varia & Definition \\
\hline $\mathrm{CT}$ & $\begin{array}{l}\text { One way commuting time of principal wage } \\
\text { earner in minutes (standardized) }\end{array}$ \\
\hline INCOME & $\begin{array}{l}\text { Household income measured in } \$ 10,000 \\
\text { intervals (standardized) }\end{array}$ \\
\hline KIDS & Number of children under age 18 in household \\
\hline ADULTS & $\begin{array}{l}\text { Number of adults (age } 18 \text { and over) in } \\
\text { household }\end{array}$ \\
\hline MAN\&PROF & $\begin{array}{l}\text { Dummy variable equals one if principal wage } \\
\text { earner holds managerial or professional job }\end{array}$ \\
\hline TS\&C & $\begin{array}{l}\text { Dummy variable equals one if principal wage } \\
\text { earner holds technical, sales or clerical job }\end{array}$ \\
\hline HISKILBLU & $\begin{array}{l}\text { Dummy variable equals one if principal wage } \\
\text { earner holds high skill blue collar job }\end{array}$ \\
\hline LOSKILBLU & $\begin{array}{l}\text { Dummy variable equals one if principal wage } \\
\text { earner holds low skill blue collar job }\end{array}$ \\
\hline TWOI & $\begin{array}{l}\text { Dummy variable equals } 1 \text { if second adult wage } \\
\text { earner in household }\end{array}$ \\
\hline
\end{tabular}

desire to own instead of rent. Long-Distance-Commuters average 50 minutes per one-way commute, hold mostly urban jobs, usually have children and non-working spouses, and are most emphatic about wanting land and a better place to raise their families.

The process used to identify these clusters, K-means cluster analysis, uses an iterative procedure to form a specified number of groups with large differences between groups and small differences within groups (Wilkinson 1987). The groups formed depend on the variables used, the way the variables are scaled, and the number of clusters specified. While different clusters can be found using other variables, the four presented here seem reasonable given the previous understanding of the data. Furthermore, these cluster 
differ in other key characteristics such as reasons for moving and distances from downtown Portland.

\section{cluster Analysis Results}

Table XXVIII presents summary statistics for the cluster analysis as well as for each cluster. The summary statistics show that KIDS is the most important variable for separating groups, followed by INCOME and commuting time (CT). The dummy occupational variables and TWOWAGE play minor roles. ADULTS is statistically insignificant and hence does not discriminate among groups. The income and commuting time variables were standardized so their larger ranges would not overwhelm the other variables.

The statistics for each cluster reveal the differences which helped determine the clusters. KIDS was an important variable for distinguishing groups with all but one family in the Child-Raising and Long-Distance-Commuting clusters having children while only about one-third of the Affluent and Economy-Minded do. The first two groups also have more children with averages of 2.48 and 1.86 children per household while the latter two groups generally have only one child, if they have any.

In terms of income, the Affluents stand out with above average incomes. Translated back to the original income categories, all Affluents have incomes over $\$ 50,000$. In contrast, the highest income of any Economy-Minded household is in the $\$ 50,000-\$ 59,000$ range. Child-Raising and Long- 
TABLE XXVIII

CLUSTER ANALYSIS RESULTS FOR EXURBAN HOUSEHOLDS WITH COMMUTING PRINCIPAL WAGE EARNERS

\begin{tabular}{|c|c|c|c|c|}
\hline Summary $s t$ & istics $(n=$ & & & Degrees of \\
\hline Variables & Between ss & Within ss & F-ratio & Freedom \\
\hline KIDS & 200.959 & 94.710 & 150.651 & 3,213 \\
\hline INCOME & 117.637 & 98.363 & 84.913 & \\
\hline CT & 91.218 & 124. & 51.903 & \\
\hline MAN\&PROF & 8.073 & 44.766 & 12.803 & \\
\hline TS\&C & 1.239 & 452 & 87 & \\
\hline HISKILBLU & 1.615 & 076 & 3.943 & \\
\hline LOSKILBLU & 0.870 & 8 & 17 & \\
\hline TWOWAGE & 2.795 & 44. & 4.412 & \\
\hline ADULTS & .479 & & 93 & \\
\hline
\end{tabular}

Affluent cluster $(n=52)$

\begin{tabular}{lrrrr} 
Variables & Minimum & Mean & Maximum & St. Dev \\
\hline KIDS & 0.00 & 0.35 & 2.00 & 0.55 \\
INCOME & 0.31 & 1.26 & 2.67 & 0.78 \\
CT & -1.54 & -0.06 & 1.37 & 0.72 \\
MAN\&PROF & 0.00 & 0.75 & 1.00 & 0.43 \\
TS\&C & 0.00 & 0.13 & 1.00 & 0.34 \\
HISKILBLU & 0.00 & 0.04 & 1.00 & 0.19 \\
LOSKILBLU & 0.00 & 0.06 & 1.00 & 0.23 \\
TWOWAGE & 0.00 & 0.69 & 1.00 & 0.46 \\
ADULTS & 1.00 & 2.13 & 5.00 & 0.59
\end{tabular}

Child-Raising cluster $(n=61)$

$\begin{array}{lrrrr}\text { Variables } & \text { Minimum } & \text { Mean } & \text { Maximum } & \text { St. Dev } \\ \text { KIDS } & 2.00 & 2.48 & 5.00 & 0.78 \\ \text { INCOME } & -1.57 & -0.09 & 2.67 & 0.76 \\ \text { CT } & -1.88 & -0.58 & 0.36 & 0.63 \\ \text { MAN\&PROF } & 0.00 & 0.38 & 1.00 & 0.48 \\ \text { TS\&C } & 0.00 & 0.08 & 1.00 & 0.27 \\ \text { HISKILBLU } & 0.00 & 0.21 & 1.00 & 0.41 \\ \text { LOSKILBLU } & 0.00 & 0.21 & 1.00 & 0.41 \\ \text { TWOWAGE } & 0.00 & 0.77 & 1.00 & 0.42 \\ \text { ADULTS } & 1.00 & 2.03 & 4.00 & 0.31\end{array}$

\begin{tabular}{lrrrr}
\multicolumn{2}{l}{ Economy-Minded } & Cluster & $(\mathrm{n}=67)$ & \\
Variables & Minimum & Mean & Maximum & St. Dev \\
\hline KIDS & 0.00 & 0.36 & 1.00 & 0.48 \\
INCOME & -1.57 & -0.64 & 0.31 & 0.55 \\
CT & -1.88 & -0.18 & 1.37 & 0.89 \\
MAN\&PROF & 0.00 & 0.31 & 1.00 & 0.46 \\
TS\&C & 0.00 & 0.21 & 1.00 & 0.41 \\
HISKILBLU & 0.00 & 0.16 & 1.00 & 0.37 \\
LOSKILBLU & 0.00 & 0.21 & 1.00 & 0.41 \\
TWOWAGE & 0.00 & 0.70 & 1.00 & 0.46 \\
ADULTS & 1.00 & 2.04 & 4.00 & 0.50
\end{tabular}


TABLE XXVIII

CLUSTER ANALYSIS RESULTS FOR EXURBAN HOUSEHOLDS WITH COMMUTING PRINCIPAL WAGE EARNERS

(continued)

Long Distance Commuters Cluster $(n=37)$

\begin{tabular}{lrrrr} 
Variables & Minimum & Mean & Maximum & St. Dev \\
\hline KIDS & 0.00 & 1.86 & 4.00 & 0.84 \\
INCOME & -1.10 & -0.45 & 1.26 & 0.56 \\
CT & 0.36 & 1.36 & 3.40 & 0.75 \\
MAN\&PROF & 0.00 & 0.22 & 1.00 & 0.41 \\
TS\&C & 0.00 & 0.30 & 1.00 & 0.46 \\
HISKILBLU & 0.00 & 0.30 & 1.00 & 0.46 \\
LOSKILBLU & 0.00 & 0.16 & 1.00 & 0.37 \\
TWOWAGE & 0.00 & 0.43 & 1.00 & 0.50 \\
ADULTS & 1.00 & 2.00 & 3.00 & 0.23
\end{tabular}

Distance-Commuters have more diverse incomes. Child-Raising incomes range from below $\$ 20,000$ to $\$ 79,999$ plus one household with over $\$ 100,000$ while Long-Distance-Commuters' incomes range from $\$ 20,000-\$ 79,999$.

The commuting times of principal wage earners range from 2 to 35 minutes in the Child-Raising cluster to 31 to 80 minutes in the Long-Distance-Commuting cluster. Mean travel times are 21 minutes for Child-Raising principal wage earners (the same as suburban principal wage earners), 28 minutes for Economy-Minded, 29 minutes for Affluent, and 50 minutes for Long-Distance-Commuters. Figure 5 shows the distribution of commuting times for each cluster for both principal and secondary wage earners. The patterns for principal and secondary wage earners from each cluster are amazingly alike. 


\section{Principal Wage Earners}

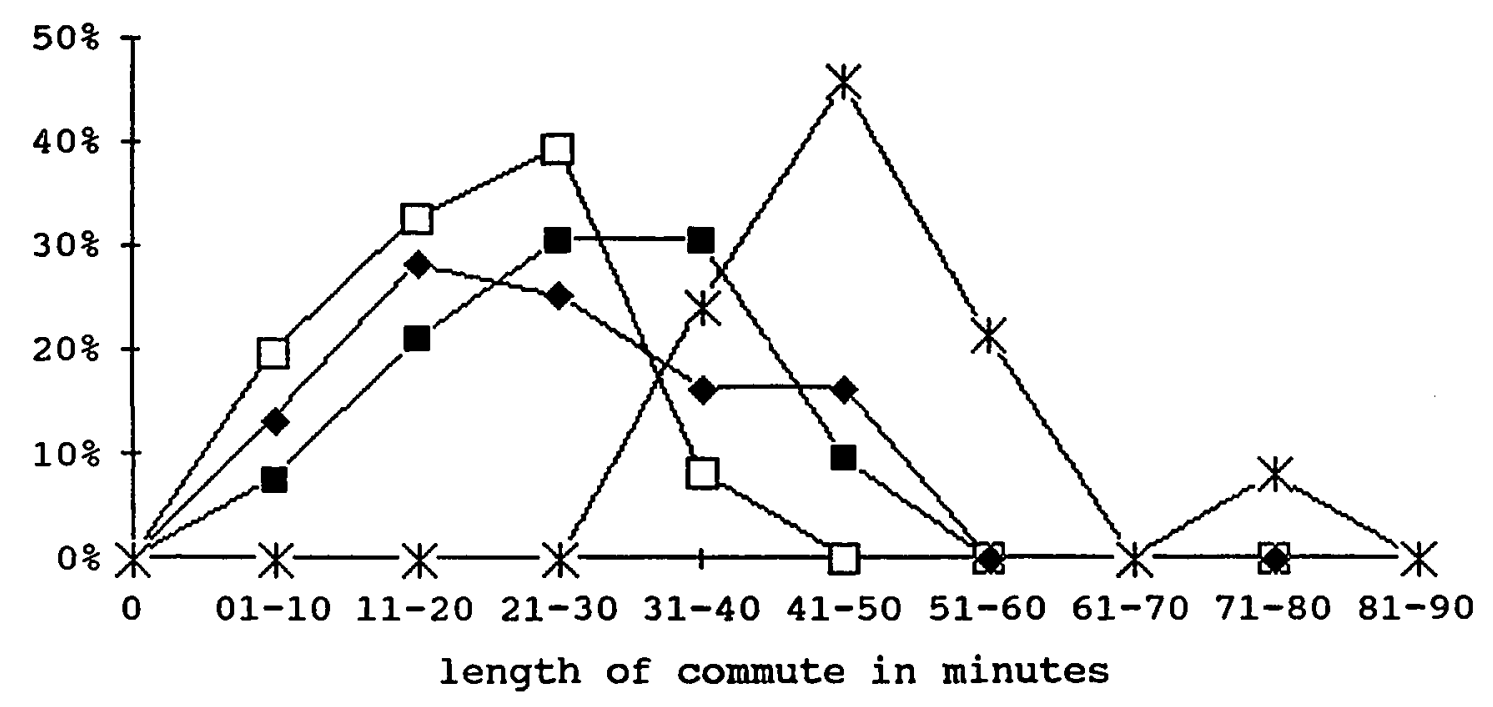

Secondary Wage Earners

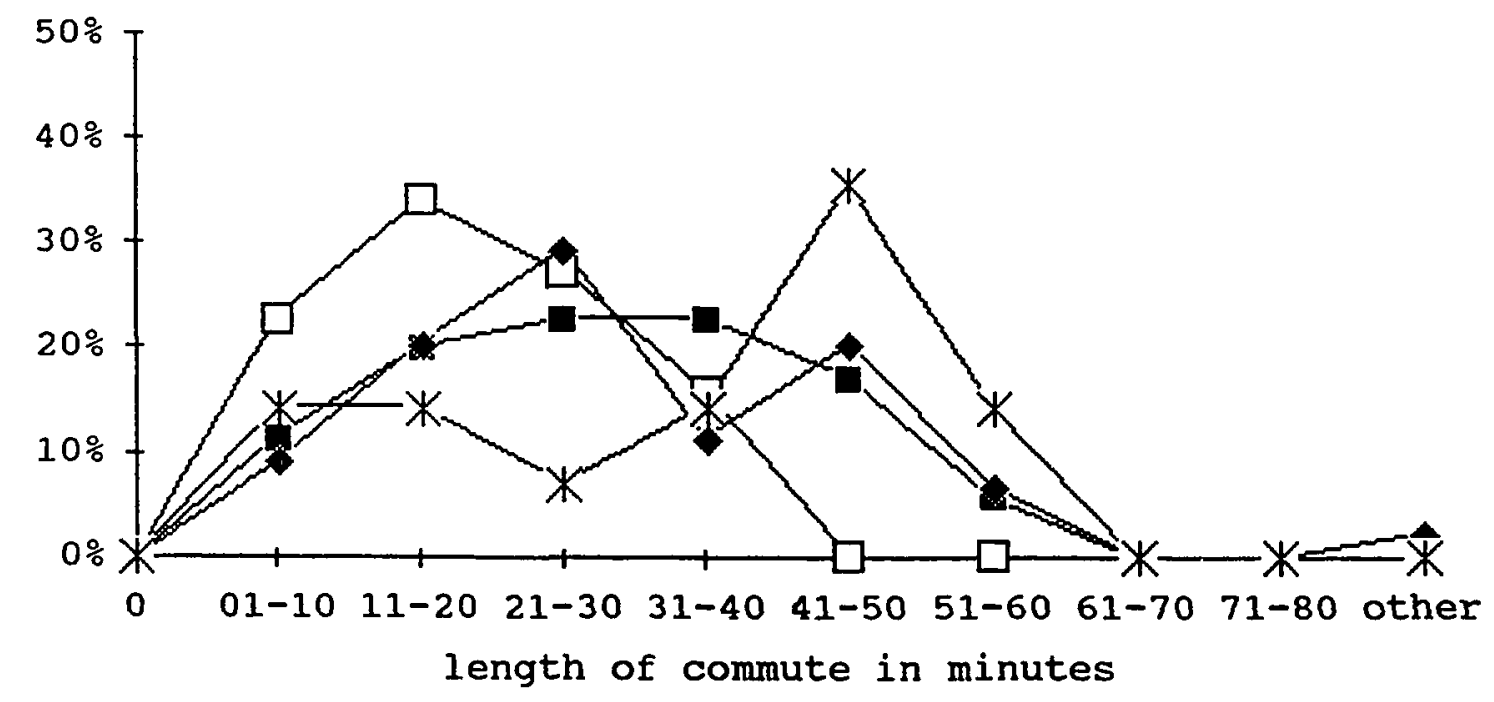

Affluent $\square$ ChildRaising
Economy- KLongMinded DistanceCommuting

Figure 5. Relative frequency of commuting times by exurban household types and type of wage earner. 
Figure 5 clearly shows the shorter trips of both types of workers from Child-Raising families and the longer trips of Long-Distance-Commuters, although the small number (14) of secondary wage earners in the latter cluster creates anerratic pattern. Affluents and Economy-Minded have the more middle distance commutes. Interestingly, secondary wage earners from these two groups have more commutes over 40 minutes in length than primary wage earners, contrary to the usual pattern of secondary wage earners working closer to home.

The occupational variables indicate that the Affluents are quite homogeneous with 75 percent of the principal wage earners having managerial and professional jobs while the other clusters are more heterogeneous. The Child-Raising cluster is closest to the overall picture of exurbia with most principal wage earners having managerial and professional or blue collar jobs. Note that in the LongDistance-Commuting cluster the major occupations are technical, sales, and clerical and high skill blue collar.

The TWOWAGE variable indicates that two wage earners are the norm in all clusters except for Long-DistanceCommuting where only 43 percent of the households include a second wage earner.

\section{other Characteristics of clusters}

These groups differ in a variety of other attributes which were important for distinguishing exurbanites from 
small town and suburban home-buyers. Table XXIX shows the variability in former place of residence. Affluents moved most often from the suburbs and least often within the exurban/small town zone. Child-Raising households have the opposite pattern of most often moving within the exurban/ small town zone and least often moving from either the urban or suburban area. Economy-Minded households are like the Child-Raising group though they less frequently came from outside the area. Long-Distance-Commuters have the highest rate of moving from the urban area although more of them moved within the exurban/small town zone than from Portland.

\section{TABLE XXIX}

PLACE OF FORMER RESIDENCE OF EXURBAN HOME PURCHASERS BY HOUSEHOLD TYPES

$\begin{array}{lccccc}\text { Former Residence } & \text { Exurban } & \text { Affl } & \text { CR } & \text { EM } & \text { LDC } \\ \text { Urban } & 16 \% & 14 \% & 13 \% & 15 \% & 25 \% \\ \text { Suburban } & 38 \% & 50 \% & 31 \% & 35 \% & 31 \% \\ \text { Exurban/Small Town } & 29 \% & 18 \% & 34 \% & 32 \% & 28 \% \\ \begin{array}{l}\text { Out-of-area } \\ \quad \text { Total }\end{array} & \frac{18 \%}{101 \%} & \frac{18 \%}{100 \%} & \frac{21 \%}{99 \%} & \frac{17 \%}{99 \%} & \frac{17 \%}{101 \%} \\ \quad \begin{array}{l}\text { Number } \\ \text { Affl = Affluent, CR = Child-Raising, EM }\end{array} & =\text { Economy-Minded, } \\ \text { LDC = Long-Distance-Commuting } & \end{array}$

Having a large lot or acreage is a major reason for moving for all household types, as shown in Table XXX, but is most important to the Long-Distance-Commuters. The Economy-Minded differ by placing just as much emphasis on owning instead of renting as on having space. The secondranked reason for moving to exurbia is to live in a more 
TABLE XXX

THE THREE MOST IMPORTANT REASONS FOR MOVING OF EXURBAN HOME PURCHASERS BY HOUSEHOLD TYPES

$\begin{array}{llcccc}\text { Reasons* } & \text { Exurban } & \text { Affl } & \text { CR } & \text { EM } & \text { LDC } \\ \text { Large lot or acreage } & 61 \% & 63 \% & 59 \% & 58 \% & 70 \% \\ \text { Live in more rural area } & 50 \% & 60 \% & 36 \% & 55 \% & 51 \% \\ \text { Own instead of rent } & 36 \% & 29 \% & 28 \% & 58 \% & 46 \% \\ \text { Better place to raise } & & & & & \\ \quad \text { family } & 27 \% & & 33 \% & & \\ \text { Different size house } & 18 \% & 29 \% & 23 \% & & \\ \text { Different quality house } & 17 \% & & 23 \% & & \\ \text { To be closer to work } & 13 \% & & 23 \% & & \end{array}$

\begin{tabular}{llllll} 
Number & 254 & 52 & 61 & 67 & 37 \\
\hline
\end{tabular} * List of reasons abbreviated from Table XVI to those rates of at least 20 percent for any household type shown.

Affl = Affluent, $C R=$ Child-Raising, $E M=$ Economy-Minded, LDC $=$ Long-Distance-Commuting

rural area, except that Long-Distance-Commuters placed more emphasis on having a better place to raise their families. But note the wide variation in the percent who wanted to live in a more rural area. This was important to 60 percent of the Affluent but only 36 percent of the Child-Raising households, possibly because more of the latter group already lived in a rural area before their move. Overall, the Child-Raising group has the most diverse list of reasons for moving including considerable interest in some reasons more often cited by suburban and small town home-buyers, namely housing quantity and quality and proximity to work. The Long-Distance-Commuters show the most agreement with four strongly supported reasons. 
Likewise, the household types agree on the most important reasons for selecting a particular neighborhood, but disagree on lesser reasons. Table XXXI shows that neighborhoods are usually selected because the best or most affordable house is there or because of the looks or design of the neighborhood. Affluent and Economy-Minded households often added other rural attributes to the list of reasons provided in the survey. As one would expect the groups with the most children, Child-Raising and Long-DistanceCommuting, show the most interest in schools. Convenience to jobs and access to freeways and highways is important to

TABLE XXXI

THE THREE MOST IMPORTANT REASONS FOR SELECTING A PARTICULAR EXURBAN NEIGHBORHOOD BY HOUSEHOLD TYPES

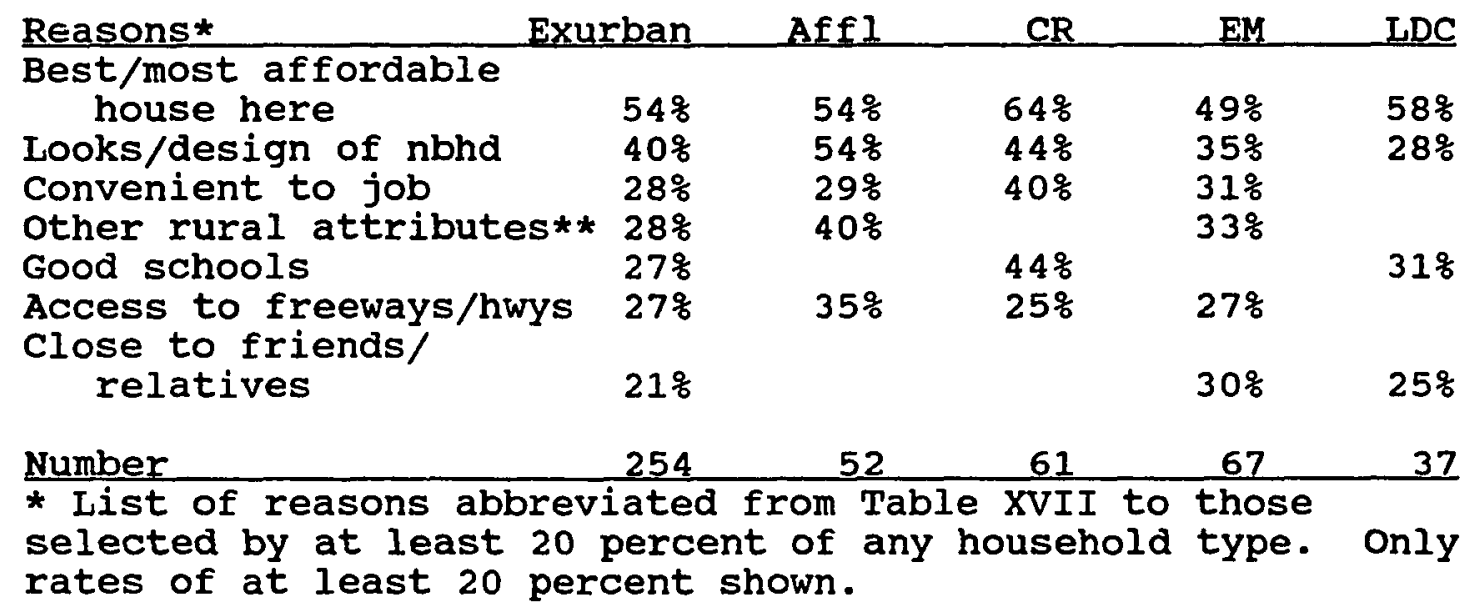

** Other rural attributes are reasons written in by some respondents such as wanting to own land for particular purposes or a desire for quiet and privacy.

Affl = Affluent, $C R=$ Child-Raising, EM = Economy-Minded, LDC = Long-Distance-Commuting 
all except Long-Distance-Commuters. Being close to friends and relatives mattered most to the Economy-Minded and LongDistance-Commuters.

Given the strong emphasis of Long-Distance-Commuters on owning land, it is not surprising that they have both the highest rate of owning lots of 5 or more acres and the highest median lot size as shown in Table XXXII. Affluents also own a substantial number of larger lots and have a large median lot size. In contrast, most Child-Raising and Economy-Minded households live on smaller lots.

TABLE XXXII

SIZE OF LOTS PURCHASED IN EXURBIA BY HOUSEHOLD TYPES

\begin{tabular}{|c|c|c|c|c|c|}
\hline Lot size & rban & Aff 1 & $\mathrm{CR}$ & EM & LDC \\
\hline $\begin{array}{l}\text { Less than } 1 \text { acre } \\
1-4.99 \text { acres } \\
5 \text { or more acres }\end{array}$ & $\begin{array}{l}15 \% \\
50 \% \\
35 \%\end{array}$ & $\begin{array}{l}14 \% \\
45 \% \\
41 \%\end{array}$ & $\begin{array}{l}16 \% \\
59 \% \\
26 \%\end{array}$ & $\begin{array}{l}14 \% \\
55 \% \\
31 \%\end{array}$ & $\begin{array}{l}16 \% \\
35 \% \\
49 \%\end{array}$ \\
\hline Median lot size (acres) & 2.5 & 4.0 & 2.3 & 2.0 & 4. \\
\hline Number & 254 & 52 & 61 & 67 & \\
\hline
\end{tabular}

Seventeen, or 7.8 percent, of the exurban residences are mobile homes. As expected, the Economy-Minded own the majority (9) of this type of housing followed by childRaising (6) and surprisingly Affluents (2).

Prices paid for housing are more closely related to income than to lot size. The mean price of an exurban house was $\$ 78,192$. Affluents paid considerably more with an average price of $\$ 103,477$. The Child-Raising households 
were closest to average with mean house price of $\$ 80,296$. Both Economy-Minded and Long-Distance-Commuting households have lower than average costs with means of $\$ 62,639$ and $\$ 67,349$, respectively. The Long-Distance-Commuters must be seeking bargains on property since they have the largest median lot size but a low average price.

Based on the different distributions of commuting times of these household types, the Child-Raising cluster might be expected to live closest to the urban center, Affluents and Economy-Minded at middle distances, and Long-Distance Commuters farthest out. The actual distribution is more complex as illustrated in Figure 6. Affluents tend to live closer-in with over half living 15-19 miles from the urban center. Their average distance from the CBD is 20.6 miles. Curiously, they are also the most dispersed group including both the closest-in and farthest-out households. ChildRaising households are most common at 15-19 miles too, but more of them live farther out giving a mean distance of 21.2 miles from the CBD. Despite very different commuting patterns, the Economy-Minded and Long-Distance-Commuting clusters have similar residential distributions with mean distances from the CBD of 22.0 and 22.6 miles, respectively. clearly, commuting time must be related to factors other than residential distance from the CBD. Table XXXIII shows another important factor--job location. Principal wage earners from the Long-Distance-Commuting group have the 


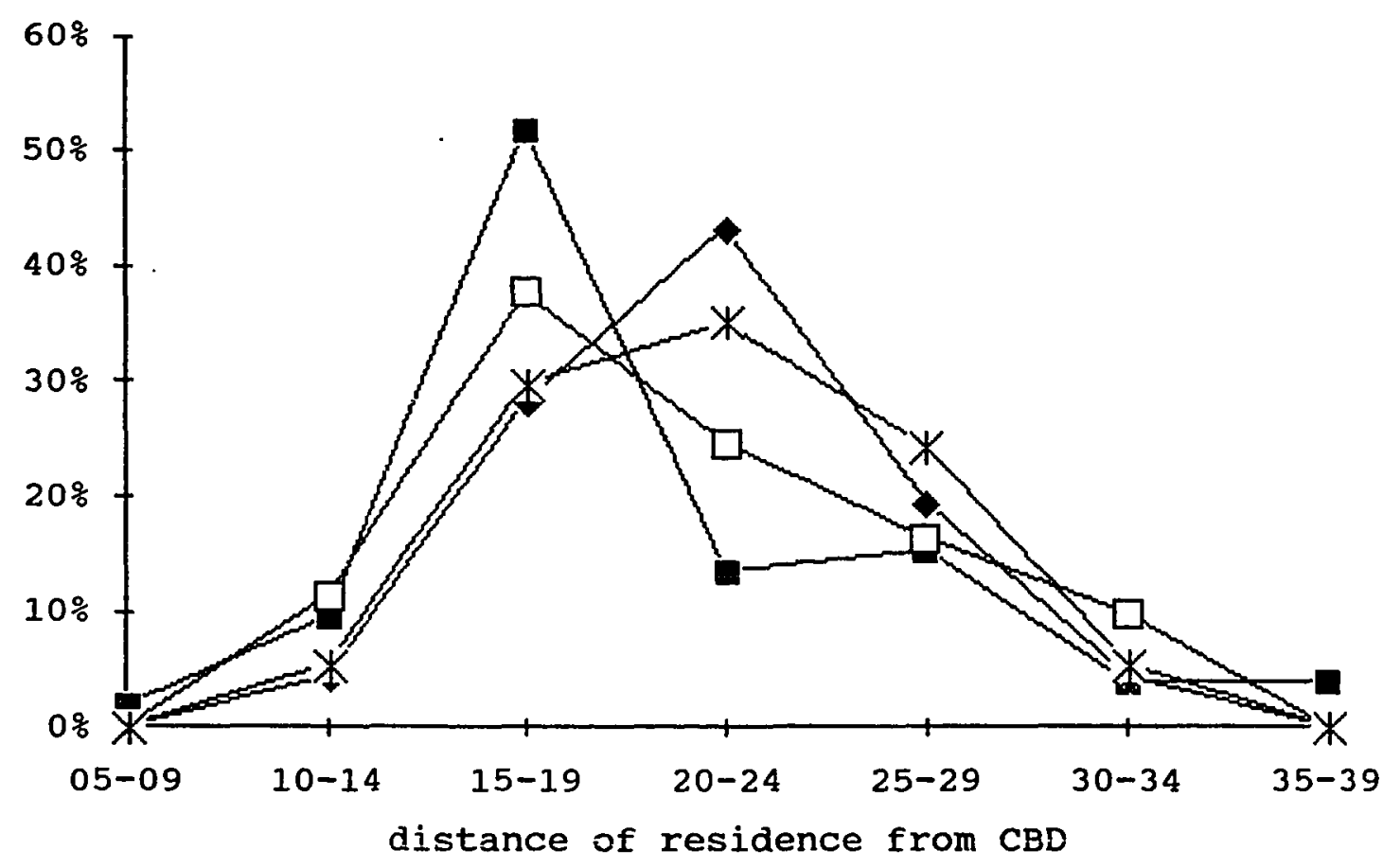

$\begin{array}{ccc}\text { Affluent } & \square \text { Child- } \\ \text { Raising } & \text { Economy- } & \text { Klong- } \\ & \text { Minded } & \text { Distan }\end{array}$

Commuting

Figure 6. Distribution of distances from Portland's central business district of exurban principal wage earners' residences by household types. 
TABLE XXXIII

JOB LOCATIONS OF EXURBAN PRINCIPAL WAGE EARNERS BY HOUSEHOLD TYPES

\begin{tabular}{lrrrrr} 
Job Location & Exurban & Affl & CR & EM & LDC \\
\hline Urban & $44 \%$ & $46 \%$ & $28 \%$ & $40 \%$ & $73 \%$ \\
Suburban & $35 \%$ & $40 \%$ & $36 \%$ & $37 \%$ & $19 \%$ \\
Exurban/Smal1 Town & $22 \%$ & $13 \%$ & $36 \%$ & $23 \%$ & $8 \%$
\end{tabular}

$\begin{array}{llllll}\text { Number } & 254 & 52 & 61 & 67 & 37\end{array}$

Aff1 = Affluent, $C R=$ Child-Raising, EM = Economy-Minded,

LDC = Long-Distance-Commuting

strongest job links to the urban core with 73 percent urban jobs. Affluents have strong ties to both suburban and urban jobs. Child-Raising principal wage earners are least likely to work in the urban area and most likely to work in exurban/small town locations. The Economy-Minded have a mix of job locations similar to the overall exurban pattern.

\section{Summary}

Four distinct groups of exurban households were identifying using $\mathrm{k}$-means cluster analysis and examination of other key variables for each cluster.

The households with the individuals with the greatest propensity to commute belong to the Long-Distance-Commuters group. This is the smallest group of exurbanites (17 percent). They fulfill their strong desires to own land and raise their families in a rural setting by buying less expensive acreage farther out than the average exurbanite and commuting long distances to their mostly urban jobs. Because these households generally have only one wage earner, their household commuting time is about the same as 
in most two-wage earner households. The primary wage earner in Long-Distance-Commuting household usually holds a high skill blue collar or technical, sales, and clerical job. The next size group (24 percent of exurbanites) are the Affluents. Like suburban home-buyers, Affluents frequently moved from the suburbs, hold a mix of urban and suburban jobs, and are generally managers and professionals. What distinguishes them from suburbanites is their desire to own large lots and live in a more rural environment. Affluents tend to live closer to the urban area than other household types.

The second largest group, the 28 percent classified as Child-Raising, shows the least propensity to commute. Because they rarely hold urban jobs, the average commutes of Child-Raising primary and secondary wage earners are the same length as the average suburban commutes. These families with two or more children and generally two wage earners may have bought homes close to their jobs to allow more time for family responsibilities. Like small town home-buyers, Child-Raising households often moved within the exurban/small town zone and gave family and housing factors as reasons for moving. They do, however, place more emphasis on owning land than small town buyers.

The largest group, the 31 percent called EconomyMinded, generally have lower incomes and buy smaller, less expensive properties. They are a diverse group in terms of 
former residences, reasons for moving and selecting a neighborhood, occupation, job location, and commuting times. Because the majority of the Economy-Minded moved in order "to own instead of rent", it would be interesting to know if they are young, first-time buyers. But, alas, the survey did not obtain that information.

\section{CONCLUSIONS}

These descriptive results suggest that many of the research hypotheses were wrong. Exurbanites do commute farther than suburbanites. Exurbanites do not use flextime and working at home as trip management strategies more frequently than suburbanites. Exurbanites are no more likely than suburbanites to carpool and, in fact, are most likely of all groups to drive alone. Lower income households do not have above average propensities to commute in comparison to other exurbanites.

Difference of means hypothesis testing can be used to more rigorously show that exurban home-buyers commute longer distances than suburban home-buyers. Using data from Table XIX, Table XXXIV shows that the differences in mean commuting times of home-buyers from different subareas are all statistically significant. In particular, we are more than 99 percent confident that there is a difference in exurban and suburban commuting times for both principal and secondary wage earners. 
TABLE XXXIV

\section{DIFFERENCE OF MEAN COMMUTING TIMES HYPOTHESIS TESTING BY TYPE OF WAGE EARNERS}

$\begin{array}{lcc}\text { Subareas } & \begin{array}{c}\text { Difference in Trip } \\ \text { Length in Minutes }\end{array} & \text { t-score } \\ \text { Principal Wage Earners } & 6.1 & 3.87 * \\ \text { Exurban-Small Town } & 9.1 & 8.83 * \\ \text { Exurban-Suburban } & 3.0 & 2.19 * \\ \text { Small Town-Suburban } & & \\ \text { Secondary Wage Earners } & 11.0 & 5.85 * \\ \text { Exurban-Small Town } & 7.5 & 5.49 * \\ \text { Exurban-Suburban } & -3.5 & -2.15 * \\ \text { Small Town-Suburban } & & \\ \text { * indicates significance at } 0.01 \text { level } & \\ \text { ** indicates significance at } 0.05 \text { level } & \end{array}$

This finding of longer exurban trips is contrary to the results reported by Dueker et al. (1983). The discrepancy may be caused by different definitions of exurbia (the urban field vs. rural areas within SMSA's) different study areas (one region vs. many), different home owners (recent buyers vs. all), or different times (1989 vs. 1975). It may be that exurban commuting trips are no longer than suburban trips in other places and the Portland region is different from the norm. Alternatively, long term exurban residents could behave more like small town residents and work closer to home than recent movers do. Finally, expectations about commuting costs were different in 1975 when there were fears of unpredictable supplies of gasoline and large price increases. Since the 1970's oil crises have been forgotten, more people may be acting on their desires for a rural lifestyle despite the longer commutes this entails. Further 
research, particularly in different parts of the country, is needed to ascertain which of these explanations is correct.

The household types identified in this study were different from those hypothesized. The group with an above average propensity to commute does not have the lowest incomes. The Economy-Minded households have the lowest average incomes and the least expensive housing, but among exurbanites they have average length commutes. Rather it is the Long-Distance-Commuters who show a decided propensity to commute. While this group tends to buy property with below average prices, their average incomes and the prices of house they buy are above those of the Economy-Minded households. Factors other than income such as occupation, family structure, and attitudes about rural living apparently influence propensity to commute.

One hypothesis seems to be true for one type of exurbanites, but not for the others, is that the decentralization of employment permits many to live in exurbia without longer commutes than suburbanites. This hypothesis is true for the Child-Raising households who usually hold decentralized jobs and whose commutes take the same amount of time on average as suburbanites'. But this is not true for all other types of exurban households. Thus "many" should be changed to "some" in the hypothesis.

one hypothesis that is supported is that high income households with managerial, professional, and technical 
occupations are most likely to use flextime and working at home to help manage their commutes. However, this may not be a very important finding since so few work at home and the proportion who use flextime is about the same as in the suburbs.

one major finding of this chapter that was not hypothesized is that exurban and small town home-buyers are very different. I did not anticipate the magnitude of the difference between these two groups and did not initially separate them. But a meaningful analysis does require separate treatment. That raises the question: Why are exurban home-buyers so different from small town homebuyers? Since the larger small towns serve as trade and job centers, why aren't the lives of exurban residents centered on them?

A central difference between exurban and small town home-buyers is their distances from downtown Portland. Although the maximum distance for both groups is about the same (37 miles), some exurban lots abut the metropolitan urban growth boundary and are as close as 9.4 miles from downtown Portland. All the small towns are farther away or they would be considered suburban. Consequently, the average exurban resident lives 21.5 miles from downtown Portland while the average small town resident lives 27.1 miles away. 
Since many exurbanites live closer to suburbs than to small towns, their children go to suburban schools and they work and shop in the suburbs or city. It may be that exurbanites who live farther out behave more like small town residents. Except for the Long-Distance-Commuters, more remote exurbanites may work mainly in exurban/small town locations and commute less often to the urban/suburban core. The next chapter will examine that possibility more fully.

In sum, most exurban home-buyers seem to be trading-off longer commutes for more desirable housing as the bid-rent model of urban form predicts they will. The next chapter will analyze that issue, along with others, more thoroughly. 
CHAPTER V

ANALYTICAL RESULTS

The average exurban home buyer commutes farther than the average suburban home buyer in order to have more space and a more rural environment. But do all exurbanites follow the same pattern? Are some willing to commute more than others? Does family structure or type of job influence commuting decisions? Are there advantages, such as cheaper housing, to longer commutes? This chapter seeks answers to these questions.

Regression analysis is used to examine the relationships between commuting time and the commuters' residential location and personal, family, and job characteristics. Additional regression analysis evaluates the impact of residential location on housing prices. The main findings are that:

1. Exurbanites commute farther than suburbanites.

2. Workers who live farther from the urban center hold more suburban jobs than those who live closer in. 3. The distance exurban commuters are willing to travel to work is constrained by other family members. 4. Occupation influences the distances people commute. 
5. Some people live farther from work because of flextime.

6. Exurban housing prices decline with distance from the urban center, but suburban housing prices do not.

\section{ESTIMATION OF COMMUTING TIME}

Commutes can be measured in either time or distance. Time is the dependent variable in this study because individuals and households have time budgets, not distance budgets. They must allocate the hours of the day to work, home responsibilities, leisure, sleep, commuting, and other activities. The time allocations of one individual in a household may affect the time allocations of others. The commuting analysis includes variables that measure some of the ways that individuals and other members of their households use time, making time the crux of the analysis.

Distance is, of course, closely related to commuting time. But the previous chapter showed that speeds of travel are faster for exurbanites than for suburbanites. A time measure takes this into account while a distance measure would not. Therefore time is the preferred measure of commuting length.

Some of the commuters were excluded from the regression analysis because of missing data. When only one or two variables were missing, these variables were usually estimated. See Appendix B for details on the treatment of 
missing variables. The variables used in the regressions are defined in Table XXXV. See Appendix $C$ for summary statistics on these variables.

Equations were estimated separately for principal and secondary wage earners. The results for principal wage earners are presented in Table XXXVI and for secondary wage earners in Table XXXVII. Each table includes results for the combined exurban and suburban sample and for the samples from each subarea. No results are presented for small town residents because regression analysis explains very little about their commuting times and the descriptive analysis has shown that small town home purchasers are quite different from both exurban and suburban home buyers.

While one-tailed t-tests could be used with EXURB, DCBD, INCOME, MODE, SEX, and WORKHM whose direction of influence is predictable, the other variables could be positive or negative. For example KIDS, the number of children, decreased fathers' commuting in one study (Singell and Lillydahl 1986) and increased it, but only for some fathers, in others (Madden 1981, White 1986). Many of the household variables are like that. In addition, the occupational dummy variables could have a mix of positive and negative signs if the reference occupations (that is, those unspecified) are not those with the longest or shortest commutes. Thus for convenience two-tailed significance is reported for all variables. 
TABLE XXXV

DEFINITION OF VARIABLES IN COMMUTING TIME ESTIMATION

Dependent Variable

CT One way commuting time in minutes

Residential Location Variables

EXURB Dummy variable equals 1 if exurban, 0 if

suburban (used only with combined samples)

DCBD Distance from traffic zone centroid to center of downtown Portland

Household Variables

INCOME

KIDS

ADULTS

HOURS ( Sp)

TWOWAGE
Household income measured in $\$ 10,000$ intervals

Number of children under age 18 in household Number of adults (age 18 and over) in household

Number of hours of work per week of spouse or other adult

Dummy variable equals 1 if second adult wage earner in household (used only with principal wage earners)

Individual Variables

SEX

MODE

Dummy variable equal to 1 if commuter is male Dummy variable equal to 1 if drives alone

Job Variables

HOURS ( COM)

WORKHM

FLEXTM

JOBCHG

MAN\&PROF

TS\&C

SERVICE

HISKILBLU

LOSKILBLU
Number of hours of work per week of commuter Number of hours works at home each week Dummy variable equals 1 if has flextime and uses it to avoid rush hour traffic Dummy variable equals 1 if earner has changed job locations since moving

Dummy variable equals one if holds managerial or professional job

Dummy variable equals one if holds technical, sales or clerical job

Dummy variable equals one if holds service job (used only with secondary wage earners) Dummy variable equals one if holds high skill blue collar job (used only with principal wage earners)

Dummy variable equals one if holds low skill blue collar job (used only with principal wage earners) 
TABLE XXXVI

REGRESSION EQUATIONS OF COMMUTING TIME OF PRINCIPAL WAGE EARNERS FOR COMBINED SAMPLE, EXURBAN SAMPLE, AND SUBURBAN SAMPLE

Variable combined Exurban

Suburban

Residential Location

EXURB

$$
\begin{array}{r}
6.985 \\
(4.482) *
\end{array}
$$

DCBD

$$
\begin{array}{r}
0.218 \\
(1.948) * * \star
\end{array}
$$

$$
\begin{array}{r}
0.059 \\
(0.329)
\end{array}
$$

0.397

$(2.508) * *$

Household

INCOME

$$
\begin{array}{r}
-0.222 \\
(-0.906)
\end{array}
$$

KIDS

$$
\begin{array}{r}
-0.377 \\
(-0.954)
\end{array}
$$

$$
\begin{array}{r}
-0.186 \\
(-0.332)
\end{array}
$$

$-0.362$

$(-0.417)$

ADULTS

$$
-1.302
$$$$
(-1 \cdot 318)
$$

HOURS ( $\mathrm{Sp}$ )

0.110

$$
(2.077) * *
$$

$$
\begin{array}{r}
-4.519 \\
(-2.043) * *
\end{array}
$$

$-0.304$

$(-1.191)$

TWOWAGE

$$
-3.381
$$$$
(-1.629)
$$

$$
\begin{array}{r}
0.157 \\
(1.497)
\end{array}
$$

$-8.471$

$(-2.092) * *$

$$
\begin{array}{r}
-0.351 \\
(-0.849)
\end{array}
$$

$$
\begin{array}{r}
0.167 \\
(0.162)
\end{array}
$$

Individual

$$
\text { SEX }
$$

$$
\begin{array}{r}
0.661 \\
(0.481)
\end{array}
$$

MODE

$$
\begin{array}{r}
-5.421 \\
(-3.531) *
\end{array}
$$$$
(-1.883) * * *
$$

$$
-0.595
$$$$
(-0.185)
$$

$$
0.061
$$$$
(1.023)
$$

$$
\begin{array}{r}
-0.253 \\
(-0.109)
\end{array}
$$

$\frac{\text { Job }}{\text { HOURS ( COm) }}$

$$
\begin{array}{r}
0.057 \\
(0.967)
\end{array}
$$

WORKHM

$$
-0.014
$$$$
(-0.115)
$$

FLEXTM

3.055

$$
(2.747) \text { * }
$$

JOBCHG

3.974

$$
(2.912) \text { * }
$$

MAN\&PROF

$$
-0.015
$$$$
(-0.110)
$$

$-0.279$

$(-1.061)$

5.049

$(2.067) * *$

4.149

(1.479)

6.929

$(1.666) * \star *$
0.027 $(0.020)$<smiles></smiles>
$(-3.185) *$

0.074

(1.218)

0.113

$(0.903)$

1.837

(1.579)

$$
\begin{array}{r}
3.467 \\
(2.304)^{* *} \\
2.785 \\
(1.156)
\end{array}
$$

4.683

$(2.205) * *$ 
TABLE XXXVI

REGRESSION EQUATIONS OF COMMUTING TIME OF PRINCIPAL WAGE EARNERS FOR COMBINED SAMPLE, EXURBAN SAMPLE, AND SUBURBAN SAMPLE (continued)

\begin{tabular}{|c|c|c|c|}
\hline Variable & Combined & Exurban & Suburban \\
\hline TS\&C & $\begin{array}{r}6.757 \\
(3.109)^{*}\end{array}$ & $\begin{array}{r}11.391 \\
(2.581) * *\end{array}$ & $\begin{array}{r}3.380 \\
(1.381)\end{array}$ \\
\hline HISKILBLU & $\begin{array}{r}7.196 \\
(3.019) *\end{array}$ & $\begin{array}{r}9.750 \\
(2.269) * *\end{array}$ & $\begin{array}{r}4.793 \\
(1.685) * \star *\end{array}$ \\
\hline LOSKILBLU & $\begin{array}{r}5.633 \\
(2.337) * *\end{array}$ & $\begin{array}{r}7.489 \\
(1.736)^{* \star *}\end{array}$ & $\begin{array}{r}3.516 \\
(1.218)\end{array}$ \\
\hline CONSTANT & $\begin{array}{r}17.197 \\
(4.188) *\end{array}$ & $\begin{array}{r}39.524 \\
(3.984) *\end{array}$ & $\begin{array}{r}13.745 \\
(3.162) *\end{array}$ \\
\hline $\begin{array}{l}\text { Adjusted } \mathrm{R}^{2} \\
\text { F-ratio } \\
\text { Degrees of freedon }\end{array}$ & $\begin{array}{r}0.165 \\
8.597 \\
\mathrm{~m} \quad 17,623\end{array}$ & $\begin{array}{r}0.090 \\
2.337 \\
16,200\end{array}$ & $\begin{array}{r}0.049 \\
2.357 \\
16,407\end{array}$ \\
\hline Mean of commute $t$ & ime $\quad 23.7$ & 29.7 & 20 \\
\hline
\end{tabular}

Numbers in parentheses are $t$-scores.

* indicates two-tailed significance at 0.01 level

** indicates two-tailed significance at 0.05 level

*** indicates two-tailed significance at 0.10 level 
TABLE XXXVII

\section{REGRESSION EQUATIONS OF COMMUTING TIME OF SECONDARY WAGE EARNERS FOR COMBINED SAMPLE, EXURBAN SAMPLE, AND SUBURBAN SAMPLE}

\begin{tabular}{|c|c|c|c|}
\hline Variable & Combined & Exurban & Suburban \\
\hline \multicolumn{4}{|c|}{ Residential Location } \\
\hline EXURB & $\begin{array}{r}6.306 \\
(4.531) *\end{array}$ & & \\
\hline $\mathrm{DCBD}$ & $\begin{array}{r}0.185 \\
(1.211)\end{array}$ & $\begin{array}{r}0.148 \\
(0.647)\end{array}$ & $\begin{array}{r}0.258 \\
(1.145)\end{array}$ \\
\hline \multicolumn{4}{|l|}{ Household } \\
\hline INCOME & $\begin{array}{r}-0.305 \\
(-0.862)\end{array}$ & $\begin{array}{r}-0.393 \\
(-0.535)\end{array}$ & $\begin{array}{r}-0.240 \\
(-0.632)\end{array}$ \\
\hline KIDS & $\begin{array}{r}-2.080 \\
(-3.539) *\end{array}$ & $\begin{array}{r}-3.792 \\
(-3.319) *\end{array}$ & $\begin{array}{r}-1.081 \\
(-1.655)^{* * *}\end{array}$ \\
\hline ADULTS & $\begin{array}{r}-2.900 \\
(-1.627)\end{array}$ & $\begin{array}{r}-5.346 \\
(-1.436)\end{array}$ & $\begin{array}{r}-1.619 \\
(-0.838)\end{array}$ \\
\hline HOURS ( Sp) & $\begin{array}{r}0.099 \\
(1.449)\end{array}$ & $\begin{array}{r}0.226 \\
(1.928)^{* \star \star \star}\end{array}$ & $\begin{array}{r}0.001 \\
(0.009)\end{array}$ \\
\hline \multicolumn{4}{|l|}{ Individual } \\
\hline SEX & $\begin{array}{r}-0.896 \\
(-0.454)\end{array}$ & $\begin{array}{r}3.089 \\
(0.739)\end{array}$ & $\begin{array}{r}-2.403 \\
(-1.122)\end{array}$ \\
\hline MODE & $\begin{array}{r}-8.469 \\
(-3.896) *\end{array}$ & $\begin{array}{r}-10.165 \\
(-2.131) * \star\end{array}$ & $\begin{array}{r}-7.823 \\
(-3.438) \text { * }\end{array}$ \\
\hline Job & & & \\
\hline HOURS ( COM ) & $\begin{array}{r}0.191 \\
(3.258) *\end{array}$ & $\begin{array}{r}0.291 \\
(2.673) *\end{array}$ & $\begin{array}{r}0.145 \\
(2.116) * *\end{array}$ \\
\hline WORKHM & $\begin{array}{r}0.141 \\
(0.788)\end{array}$ & $\begin{array}{r}0.195 \\
(0.617)\end{array}$ & $\begin{array}{r}0.122 \\
(0.571)\end{array}$ \\
\hline FLEXTM & $\begin{array}{r}3.863 \\
(2.254) \star *\end{array}$ & $\begin{array}{r}3.514 \\
(1.096)\end{array}$ & $\begin{array}{r}4.603 \\
(2.345) * *\end{array}$ \\
\hline JOBCHG & $\begin{array}{r}-1.439 \\
(-0.949)\end{array}$ & $\begin{array}{r}0.559 \\
(0.195)\end{array}$ & $\begin{array}{r}-2.791 \\
(-1.622)\end{array}$ \\
\hline MAN\&PROF & $\begin{array}{r}-4.218 \\
(-1.646)\end{array}$ & $\begin{array}{r}-4.071 \\
(-0.881)\end{array}$ & $\begin{array}{r}-3.423 \\
(-1.087)\end{array}$ \\
\hline TS\&C & $\begin{array}{r}-4.545 \\
(-1.914)^{* * *}\end{array}$ & $\begin{array}{r}-4.640 \\
(-1.123)\end{array}$ & $\begin{array}{r}-3.960 \\
(1.340)\end{array}$ \\
\hline
\end{tabular}


TABLE XXXVII

\section{REGRESSION EQUATIONS OF COMMUTING TIME OF SECONDARY WAGE EARNERS FOR COMBINED SAMPLE, EXURBAN SAMPLE, AND SUBURBAN SAMPLE \\ (continued)}

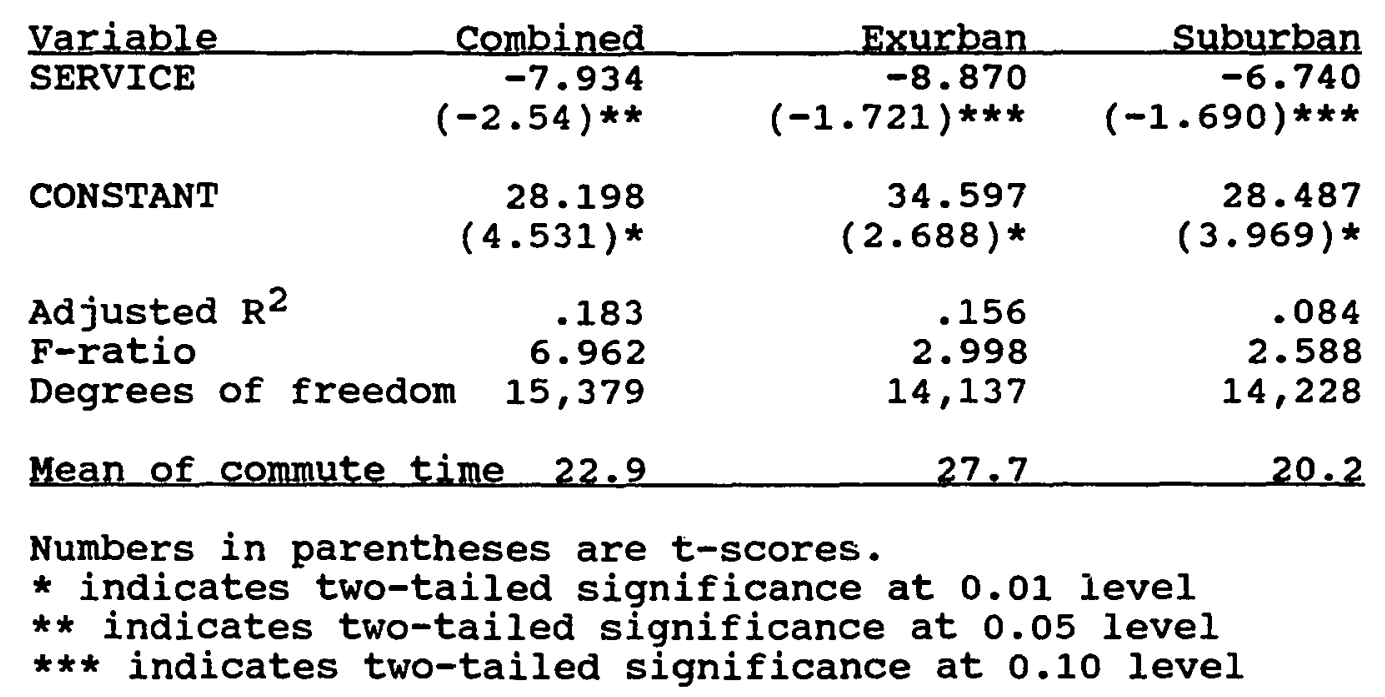

\section{General Results}

The equations explain only a small portion of the variability in commuting time, as indicated by the small adjusted $\mathrm{R}^{2}$ 's. All equations are, however, statistically significant at the one percent level. Much of the unexplained variability is probably due to the transportation network and the distribution of jobs. In addition, most of the coefficients have the expected signs, and many are statistically significant. Thus the regression equations can be used to explain how residential location and the individual, family, and job characteristics of commuters effect commuting time. 
The Chow test was used to determine whether the set of variables has the same influence on exurban and suburban home-buyers. The tests indicate that the variables have different impacts on each subgroup, and it is therefore appropriate to use separate equations for each residential subarea. The F-ratios of the chow tests are 2.550 (significant at the one percent level) for principal wage earners and 1.886 (significant at the five percent level) for secondary wage earners.

The only variables that are significant in all cases are the constant term and the MODE dummy variable. The large size of the constant terms results in part from the large amount of variability in commuting time unexplained by the variables. The coefficients for MODE demonstrate that driving alone saves 5 to 10 minutes over carpooling, transit, walking or bicycling. Comparison of these time savings with mean commuting times reveals that driving alone reduces commuting times by about one-fourth for primary wage earners and by more than one-third for secondary wage earners.

\section{Results For Residential Iocation Variables}

Given the differences in commuting time of exurbanites and suburbanites that are discussed previously, the regressions should show that exurbanites travel farther than suburbanites. The combined regression equations do that. The EXURB coefficients indicate that exurban principal wage 
earners commute about 7.0 minutes more than their suburban colieagues while exurban secondary wage earners commute about 6.3 minutes more. These results are similar to the 9.1 minute and 7.5 minute differences in mean commuting time calculated from means reported in Tables XXXVI and XXXVII. The rest of the discussion focuses on the separate exurban and suburban equations.

Distance from the central business district would be positively correlated with commuting time if everyone worked in or near the city center. But with the decentralization of employment, distance to city center may have no effect. In this study, only suburban principal wage earners have longer commutes if they live farther from Portland's central business district, and they are only willing to increase commutes by 0.4 minute per mile from the city center. The insignificance of distance from the CBD for all other workers implies that commuters within each of these groups spend the same amount of time commuting, holding other characteristics constant, whether they live close to the city center or far out. Workers living farther out must therefore work at more suburban locations (or exurban/small town locations for exurbanites) than those living closer in. This is even true for suburban principal wage earners since 0.4 additional minute per mile from the city center is not enough time to commute to the same job sites as workers who live nearer the $C B D$. The suburbanization of jobs must 
therefore be a factor encouraging exurban residential development, especially development farther from the urban center.

The lack of relationship between commuting time and distance from the $C D D$ was expected for the mostly female secondary wage earners, since women usually work closer to home (Madden 1981). That exurban principal wage earners behave differently from their suburban counterparts is more interesting. Apparently the time that exurbanites spend commuting is fairly constant. Thus those who hold urban or inner suburban jobs must live closer to the urban center than those with outer suburban or exurban/small town jobs. This conclusion is confirmed by Figure 7 which compares job locations of exurban principal wage earners with the distances of their residences from downtown Portland. The grey area shows the overall pattern. The lines for job locations clearly show that urban job holders tend to live closest to the city center with almost half living 15-19 miles out. Exurban job holders live farthest out with few at 15-19 miles from Portland, where urban and suburban job holders are most numerous, and the highest proportions from 25 to 39 miles out. The proportions of exurban, suburban, and urban job holders are about equal only at 20-24 miles from Portland.

Figure 7 also provides an outer boundary to exurban living in the Portland region. Very few urban or suburban 


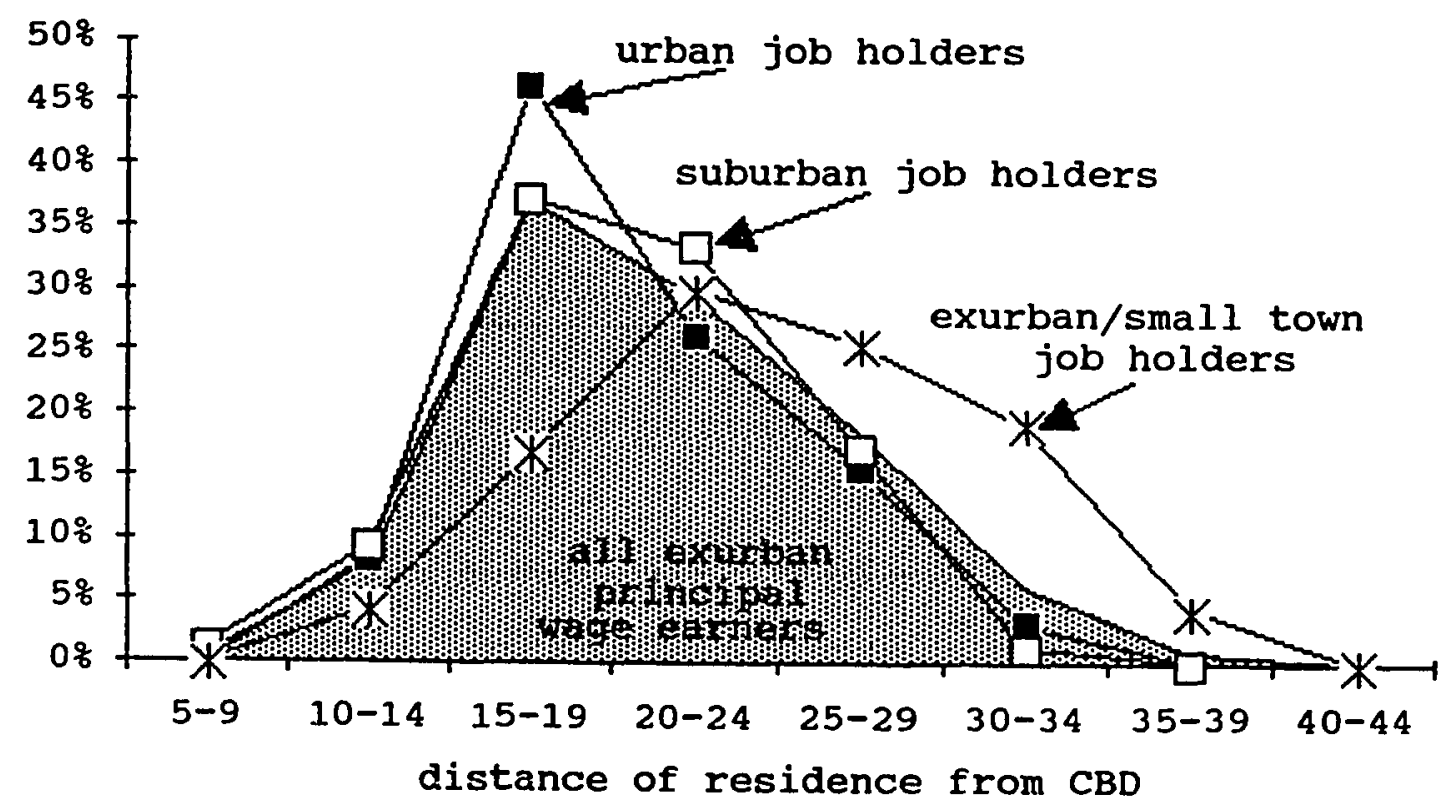

Figure 7. Distribution of distances from Portland's central business district of exurban principal wage earners' residences by jcb locations. 
workers live 30 or more miles from downtown Portland, and none live 35 or more miles out.

\section{Results For Family Variables}

The family variables show that exurban residential choice is constrained by other family members more than suburban residential choice. None of these family variables are significant for suburban principal wage earners and only KIDS appears significant for suburban secondary wage earners. But the coefficients of KIDS show a reduction of 3.8 minutes per child for exurban secondary wage earners and only 1.1 minute per child for suburban secondary earners. The significant and negative coefficients of ADULTS and TWOWAGE show that exurban principal wage earners live closer to work if there are other adults in the household and if there is a secondary wage earner. Thus a principal wage earner with a spouse who is not employed would live 4.5 minutes closer to work than a single adult, but if that spouse were employed the principa? wage earner would live an additional 8.5 minutes closer to work.

Madden (1981) reported the shortest mean commuting times for singles; so the few singles $(4.6$ percent of exurbanites) selecting exurban living must be different from the norm. ADULT also indicates that additional adults in the household such as children age 18 or older or elderly parents reduce commuting time for exurban principal wage 
earners. About 8 percent of the exurban households have more than two adults.

The commuting patterns of two-wage earner households are complicated by the various work and home roles of the two earners. Other studies do not agree on whether a second wage earner will increase, decrease, or have no effect on the primary wage earner's commuting length (Madden 1981, White 1986). Exurbanites in this study may be reducing commuting time when the household includes a second wage earner because living closer to the primary wage earner's job probably means living closer to jobs in general.

Confounding this analysis is the small, but positive and significant, coefficient on HOURS(Sp) for exurban secondary wage earners. This implies that the secondary earners have slightly. longer commutes if their spouse or partner works longer hours. That obviously leaves less time for other activities, and the opposite effect was expected. However, the longer commute could be caused by giving greater consideration to the primary wage earner's commute when selecting a residence and therefore placing the secondary wage earner somewhat at a disadvantage.

It is not surprising that family responsibilities, as measured by the number of children, reduce the commuting time of secondary wage earners although the previous empirical results are mixed (Madden 1981; Singell and Lillydahl 1986). The insignificance of KIDS for primary 
wage earners may be due to conflicting forces rather than a lack of influence. Some households may move farther from work to find a better place to raise their families as the Long-Distance-Commuting households do. Others, particularly the Child-Raising households, may locate closer to work because of the additional time needed for family responsibilities.

Income is the one family variable which is never statistically significant, implying that it has no effect on commuting. Household income is used for INCOME and may not be the correct specification, although others report significance for this specification (Madden 1981; Singell and Lillydahl 1986). Because the occupational variables are somewhat correlated with income, they may be picking up some of the influence usually attributed to income.

Results For Individual Variables

The results for mode of travel have already been discussed and the remaining individual variable sEX is statistically insignificant in all cases. This lack of significance does not mean that men and women have no differences in commuting times, which would be contrary to all other studies. Rather SEX merely indicates that male and female primary wage earners cannot be distinguished from one another: nor can male and female secondary wage earners. This is consistent with Singell and Lillydahl's (1986) 
finding that when women earn as much as men they commute about as far as the men do.

There are, however, differences between the explanatory variables of primary and secondary wage earners which should take into account the different household and employment roles of these two groups. These differences are related to gender as 84 percent of the principal wage earners are male while 86 percent of the secondary wage earners are female.

\section{Results For Job Variables}

The job variables show that the commuting times of full-time and part-time secondary wage earners differ; that flextime allows some workers to live farther from work; that changing jobs after moving only affected the commutes of suburban principal wage earners; and that occupational groups have different propensities to commute.

Hours of work per week could have either negative or positive influences on commuting. People with long hours may commute less to leave more time for other activities. Conversely, working may have more intrinsic value for those who work longer hours or may pay more, at least on a per trip basis. Thus people with longer hours may be willing to commute farther. Alternatively, long hours may increase the desire to live in an ideal location--perhaps somewhere quiet, serene, and private--even though a longer commute is required to get there. Other studies report mixed results for hours of work (Madden 1981; Singell and Lillydahl 1986). 
Nearly all the primary wage earners in the sample work full-time; so HOURS(Com) basically measures variability in full-time hours for principal wage earners. This small variability does not influence commuting time.

But HOURS(Com) is statistically significant for secondary workers. Since about one-third of them work parttime, the coefficient on HOURS(COM) can be used to interpret the differences between part- and full-time work for secondary wage earners. The coefficients indicate that a secondary wage earner who works 40 hours per week travels 5.8 more minutes per one-way trip if exurban and 2.9 more minutes if suburban than a similar secondary wage earner who works only 20 hours per week.

Flextime, which gives some workers the ability to adjust their schedules to avoid traffic congestion, results in longer commuting times for exurban principal wage earners and suburban secondary wage earners. The FLEXTM coefficients show an increase of 5.0 minutes for exurbanites primary workers and 4.6 minutes for suburban secondary workers. This seems paradoxical since avoiding rush hour should allow a faster commute which takes less time. Apparently workers who use flextime to manage their commutes move farther from work than can be compensated for by higher speeds. Perhaps commuters find traveling at off-peak hours more pleasant than at peak times and are thus willing to spend more time commuting. Or it may be that simply having 
some personal control over commuting schedules makes commuting seem less onerous and thus results in living farther from work.

Changing jobs after moving also results in longer commutes, but only for suburban primary wage earners who happen to have the lowest rate of post-move job change. only 13 percent of that group changed jobs after moving compared to 16 percent of exurban primary wage earners, 19 percent of suburban secondary wage earners, and 22 percent of exurban secondary wage earners. Apparently job changes in the other groups results in a mix of longer and shorter commutes which fails to produce significant results.

In this analysis, the coefficients of the occupational dummy variables are positive for principal wage earners because the holders of the unspecified occupations--service, agriculture, forestry, and fisheries--commute the shortest distances. The coefficients are negative for the secondary wage earners because those in the unspecified blue collar jobs commute the longest distances.

The effects of the occupational dummy variables on principal wage earner's commuting times are summarized in Table XXXVIII. The two exurban occupational groups with the longest commutes--technicai, saies, and clerical and high skill blue collar workers--are the main occupational groups in the Long-Distance-Commuting household type. At first it seems surprising that technical, sales, and clerical workers 
TABLE XXXVIII

ADDITIONAL TIME PRINCIPAL WAGE EARNERS IN VARIOUS OCCUPATIONAL GROUPS COMMUTE BY RESIDENTIAL SUBAREAS

Additional Minutes

\begin{tabular}{|c|c|c|}
\hline \multirow{2}{*}{\multicolumn{3}{|c|}{ Rank occupational Group }} \\
\hline & \multicolumn{2}{|c|}{ Exurban } \\
\hline 1 & Technical, Sales, and Clerical & 11.4 \\
\hline 2 & High Skili Blue Collar & 9.8 \\
\hline 3 & Low Skill Blue Collar & 7.5 \\
\hline 4 & Managerial and Professional & 6.9 \\
\hline 5 & Service: Agriculture or Forestry & 0.0 \\
\hline \multicolumn{3}{|c|}{ Suburban } \\
\hline 1 & High Skill Blue Collar & 4.8 \\
\hline 2 & All other & 0.0 \\
\hline
\end{tabular}

are long distance commuters. But additional analysis of this group reveals that three out of four of these 37 principal wage earners are male and that there is only one secretary, one bookkeeper, and no sales clerks in the group. Most are technicians or salespersons with moderate to very high incomes.

The long commutes of high skill blue collar workers in both exurban and suburban areas were expected. However, based on Cubikgil and Miller's (1986) finding that managers and professionals are second to high skill blue collar workers in propensity to commute, managers and professionals were expected to commute longer distances. Certainly the fact that low skill blue collar workers who have modest incomes commute farther than managers and professionals is surprising. But recall that the two household types who live closest to the urban center and have short to average 
commutes, the Child-Raising and Affluent households, also have the highest proportions of managers and professionals. Secondary workers are not included in Table XXXVIII because the only results for them are that service workers from both residential areas work closer to home than all others.

The interpretation of these results is complicated by the fact that the occupational variables measure willingness to commute, given the region's spatial structure. It isn't possible to determine how much of occupation's influence on commuting time is determined by the location of jobs relative to desirable and affordable residences and how much by attitudes toward commuting. For example, it could be that the location of jobs (such as at high tech firms in the outer portions of Washington County suburbs) allows managers and professionals to live closer to their work than other exurbanites even though they might be willing to live farther away, if necessary, to have an exurban home. It is also unclear whether suburban high skill blue collar workers have longer commutes because they cannot find suitable residences near their jobs, because they don't mind commuting, or because they change job locations frequently.

\section{Summary}

As a group, exurbanites spend more time commuting than suburbanites. But within this group, commuting times vary. Exurban principal wage earners' commuting times depend on 
the mode of travel, on the presence and employment status of other adults in the family, on the use of flextime, and on occupation. Secondary wage earners are also influenced by mode and somewhat by occupation. In addition, their travel times vary with the number of children in the family and the hours they and their spouses or partners work.

Exurbanites' commuting times do not vary, however, with distance from downtown Portland. Instead close-in exurbanites behave like suburbanites holding mostly urban and suburban jobs while distant exurbanites resemble small town residents who prefer exurban/small town jobs. Very few urban or suburban job holders live more than thirty miles from downtown Portland.

\section{ESTIMATION OF HOUSING PRICES}

Regression analysis was also used to determine how residential location affects housing prices. The analysis controls for housing characteristics and the cost and provision of some public services. The analysis is only for homes purchased by households with commuting principal wage earners.

The variables are defined in Table XXXIX. The results for the combined sample and for exurban and suburban samples are presented in Table XL. Again small town residents are omitted. 
TABLE XXXIX

DEFINITION OF VARIABLES IN PRICE ESTIMATION

Dependent Variable

PRICE Sale price of house in $\$ 1000$ 's

Residential Location Variables

EXURB Dummy variable equals 1 if exurban, 0 if suburban (used only with combined samples)

DCBD Distance from traffic zone centroid to center of downtown Portland

Housing Variables

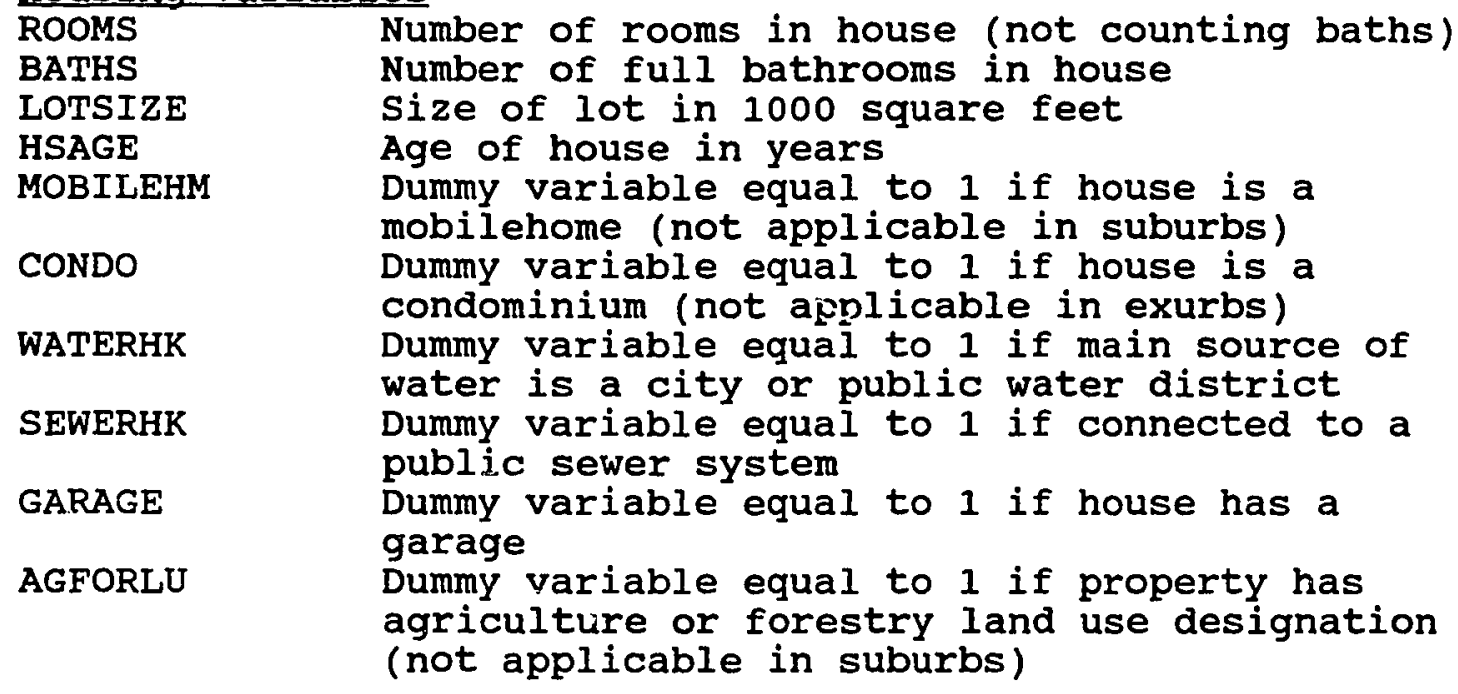

Public Services/Costs Variables

TAXR

FY 1986-87 property tax rate in dollars per

SCHLEXP

thousand dollars of assessed valuation

FY 1986-87 mean expenditure per pupil of

local school district(s) 
TABLE XL

\begin{abstract}
REGRESSION EQUATIONS FOR PRICES OF HOMES PURCHASED BY COMMUTING PRIMARY WAGE EARNERS FOR COMBINED SAMPLE, EXURBAN SAMPLE, AND SUBURBAN SAMPLE
\end{abstract}

Variable

combined

Exurban

Suburban

Residential Location

\section{EXURB}

0.114

$(0.016)$

DCBD

$-1.265$

$(-3.715)$ *

Housing Characteristics

ROOMS

4.886

$(6.192) *$

BATHS

13.551

$(5.856) *$

LOTSIZE

0.030

$(3.417) *$

HSAGE

MOBILEHM

$-0.351$

$(-3.994) *$

$(-3.471$

$(-3.131) *$

CONDO

$-6.434$

$(-0.894)$

WATERHK

$$
\begin{array}{r}
-9.134 \\
(-1.830) * *
\end{array}
$$

SEWERHK

$-2.219$

$(-0.378)$

GARAGE

4.248

$(0.842)$

AGFORLU

11.009

$(1.607) * * *$

Public Services/Costs

TAXR

$-0.939$

$(-2.447) *$

SCHLEXP
0.011

$(1.619) * * *$

$$
\begin{array}{r}
-1.997 \\
(-4.760) *
\end{array}
$$

0.053

$(0.085)$

$$
\begin{array}{r}
2.765 \\
(2.476) *
\end{array}
$$

6.211

$(5.913) *$

12.741

$(4.002) *$

13.788

$(4.440) *$

0.030

$(3.865) *$

0.198

$(2.913) *$

$-0.107$

$(0.949)$

$-0.502$

$(-3.931) *$

N.A.

-23.903
$-2.835) *$

N.A.

$-3.114$

$(-0.404)$

9.756

$(0.650)$

$(-2.024) * *$

10.344

9.021

$(0.987)$

(1.209)

5.117

$(0.876)$

1.407

$(0.168)$

N.A.
$-0.619$

$(-1.415) * * *$

0.014

$(2.396)$ *
$-2.708$

$(-3.465)$ *

0.016

$(1.341) * * *$ 
TABLE XL

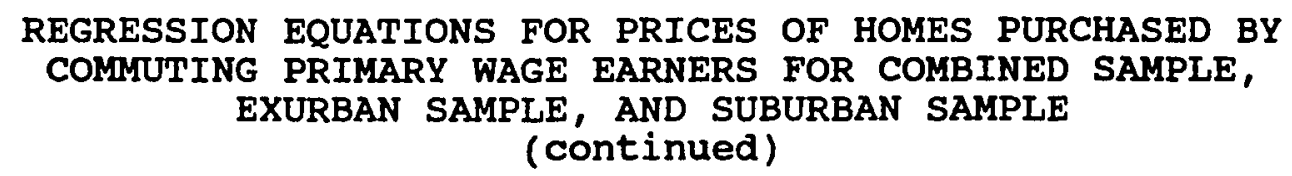

\begin{tabular}{lrrr} 
Variable & Combined & Exurban & Suburban \\
\hline CONSTANT & 24.879 & 30.678 & -6.988 \\
& $(0.917)$ & $(1.071)$ & $(0.134)$ \\
Adjusted $\mathrm{R}^{2}$ & 0.318 & 0.391 & 0.323 \\
F-ratio & 22.355 & 12.544 & 19.376 \\
Degrees of freedom & 14,626 & 12,204 & 11.412 \\
Mean of PRICE & 80.656 & 78.192 & 81.916 \\
\hline
\end{tabular}

Numbers in parentheses are t-scores.

* indicates one-tailed significance at 0.01 level

** indicates one-tailed significance at 0.05 level

*** indicates one-tailed significance at 0.10 level

\section{General Results}

Each of the equations are statistically significant at the one percent level. One-tailed significance is reported in Table XL because the direction of influence of each of the variables can be predicted. The coefficients of the control variables--housing characteristics and public services and costs--have the expected signs (except for WATERHK in the combined and exurban samples). There are some unexpected differences in some of the exurban and suburban coefficients which will be examined next before focusing on the residential location variables.

Results for Housing and Public Services/Cost Variables

Although some variables like LOTSIZE should have different effects in exurban and suburban areas, there are 
some unexpected differences. For example, an additional room increases suburban home values by more than twice the exurban amount although the number of bathrooms has approximately the same impact on price in each area. This cannot be explained by differences in the number of rooms between areas as Appendix $C$ shows that the mean number of rooms in exurbia is 7.3 and in suburbia is 7.2. Perhaps rooms are different sizes or serve different functions in each area.

Another housing quality variable that has different impacts is age. It is statistically significant only for suburban homes. But there are considerable differences in the ages of home in the two areas. The suburban houses purchased in 1987 tend to be newer with 24 percent of them under three years in age. These homes were probably new when purchased in 1987. The median age of suburban home is 10 years. In comparison, only 7 percent of the exurban homes were new in 1987, and the median age is 15 years.

As with the ROOMS variable, it is unclear why property tax rates have such different effects in the two areas. There is less difference in property tax rates inside and outside the urban growth boundaries than one might expect. As shown in Appendix $c$, the average tax rate in exurbia is $\$ 20.50$ per thousand dollars of assessed valuation and in suburbia $\$ 23.40$. There is however, more variability in exurbia with a standard deviation of $\$ 5.00$, largely due to 
some low tax areas, while the suburban standard deviation is only $\$ 2.50$.

The differences in coefficients on TAXR lead to different conclusions about the probable effects on housing values of tax rate increases to finance public schools. Following Oates' (1969) procedure it is estimated that a $\$ 1$ property tax rate increase devoted entirely to schools would increase the value of exurban homes by about $\$ 500$ bui would decrease suburban home values by $\$ 1400$. (See Appendix D for details of the calculation.) Although some of the exurban/small town school districts are noted for their low funding levels, other exurbanites live in suburban school districts. Obviously the issue is complex and further analysis is needed to fully understand the differential impacts of property taxes and school expenditures.

\section{Results For Residential Location Variables}

The remainder of the discussion will focus on the residential location variables. They are of primary interest for this study because they are also included in the commuting time analysis.

The residential location variables, EXURB and DCBD, show that housing prices decline with distance from the city center, but only in the exurban area. Contrary to the bidrent model of urban form, suburban housing prices do not appear to vary with distance from the city center. Furthermore the EXURB variable in the combined regression 
equation indicates that there is no shift in housing prices to either a higher or lower level at the urban growth boundary. Thus exurbanites appear to be the only ones making a trade-off between lower housing prices and higher transportation costs. But this trade-off does not affect all exurbanites equally as illustrated in Figure 8.

Because commuting time is constant for all exurbanites, those who live farthest out have the lowest housing prices but approximately the same commuting costs as households living closer to the urban center. Exurban households near the urban growth boundary, on the other hand, may be paying a premium for exurban living. They may not have enough housing price savings over suburbanites to recoup the additional cost of commuting. In fact, exurban housing prices near the urban growth boundary might be higher than suburban prices across the boundary because of strong demand for close-in rural lots although this is not measured here.

Among the suburbanites, those who live farther out seem to have higher costs. Housing prices appear to be constant throughout the suburbs, but residents of the outer suburbs have longer commutes than those living near the CBD and therefore higher transportation costs. It may be that the suburban bid-rent surface has peaks at suburban employment centers which are averaged with an overall decline in housing prices away from the city center to produce a flat 


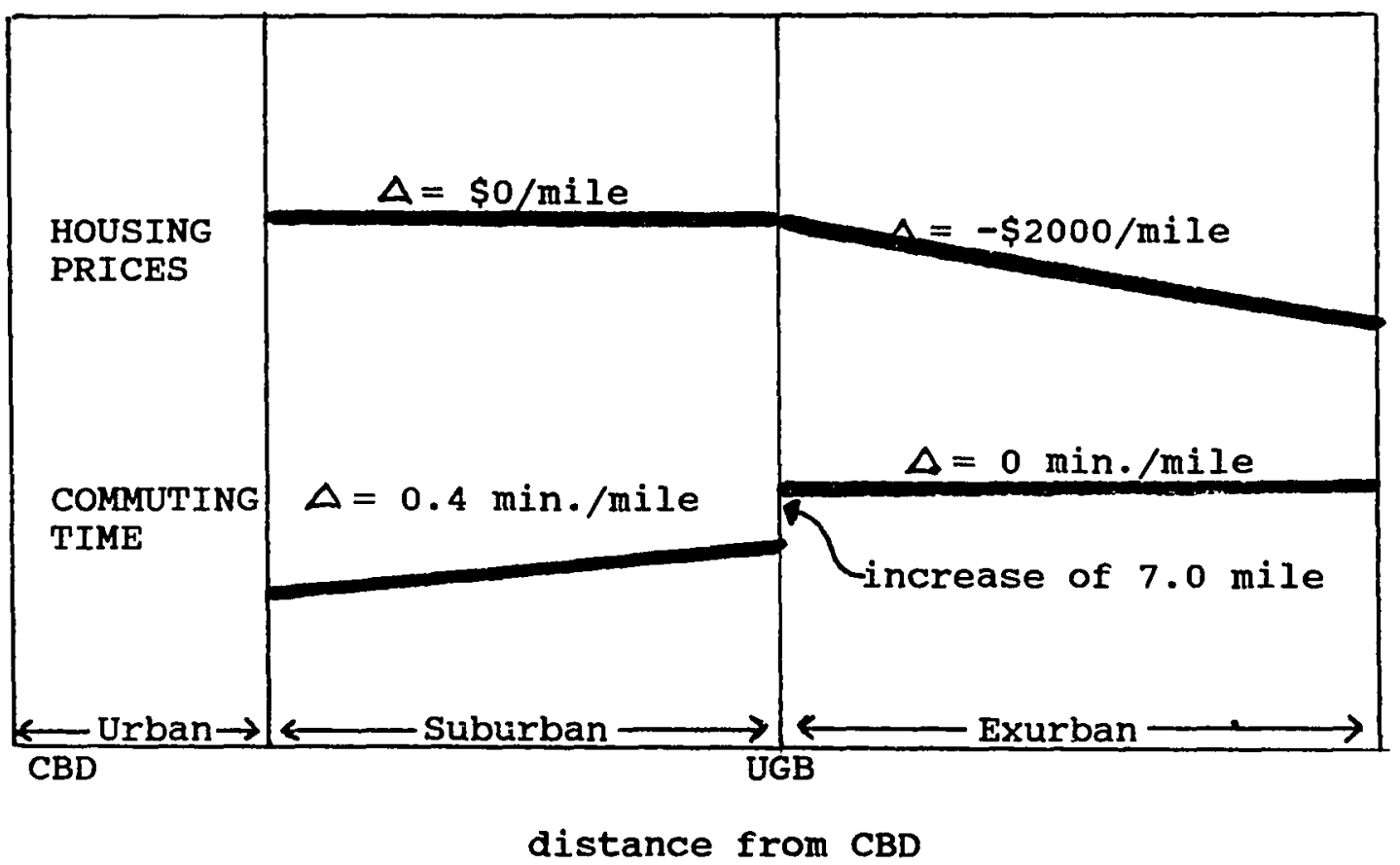

Figure 8. Effects of the the urban growth boundary (UGB) and the distance from the central business district (CBD) on suburban and exurban housing prices and principal wage earner's commuting times. 
rate. Further analysis using suburban employment centers would be needed to determine whether this is the case.

\section{Summary}

Most exurbanites are making a trade-off between lower housing prices and higher transportation costs, but this trade-off does not affect all exurbanites equally. Those who live farthest out may be reaping a windfall while those living closer-in may be paying a premium. The analysis does not indicate that suburbanites make a housing-transportation trade-off. Rather it shows that those living farther out pay more in transportation costs than those living closer in, while all pay the same housing costs. Perhaps some important factors such as suburban employment centers are missing from the suburban analysis.

\section{CONCLUSIONS}

The regression analysis confirms that the major hypothesis was in error: the commuting time of exurbanites is generally longer than that of suburbanites. But to compensate, exurbanites sort themselves out so that those living farther from the $C B D$ spend the same amount of time commuting as those living nearer the city. This suggests that a second hypothesis about the influence of decentralizing employment, though wrong, held a kernel of truth. 
The incorrect hypothesis was that the decentralization of employment allows many to live in exurbia without longer commutes than suburbanites. The conclusions to the previous chapter noted that this hypothesis is only true for the onefourth of exurbanites in the Child-Raising group. For many of the others, decentralized jobs do facilitate exurban living but do not eliminate longer commutes. What they do is extend the range of exurbia by making more remote areas an acceptable commuting distance from some jobs.

The analysis also shows that flextime has the opposite effect of that hypothesized. Rather than reducing commuting time it encourages living longer distances from work, even when distance is measured in time.

Another conclusion, which was not hypothesized, is that secondary wage earners have more influence on residential decision-making in exurbia than in suburbia. In the suburbs, secondary wage earners have no discernable impact on the length of the principal wage earner's commute. This suggest that the traditional model of choosing residential location with respect to the primary wage earners job location and housing considerations applies in the suburbs. But in the exurbs, principal wage earners have shorter commutes if the household includes a secondary wage earners implying that the jobs of both workers affect the exurban residential decision. 
Finally, this analysis shows that the bid-rent model of urban form does help explain the decision-making of exurban home-buyers. Most exurbanites are making a trade-off between longer commutes and lower housing prices when they move from the urban/suburban area. 


\section{CHAPTER VI}

\section{DISCUSSION AND CONCLUSIONS}

This case study of commuting patterns of recent exurban, small town, and suburban home buyers in the Portland, Oregon, region expands the information base on exurban residents and their journey-to-work. Transportation and land use planning has been done without clearly knowing what type of people are moving to exurbia, why they want to live there, and how exurban living affects travel to work. Scholarly writing has speculated on the forces sustaining exurban development and the impact it has on society and individuals without an adequate knowledge base. Information from this study, and hopefully others related to it, will help fill these voids.

In addition, the analysis provides some new insights about commuting in two-wage-earner families and about the impacts of flextime and occupation on commuting. Finally, the research supports the bid-rent model of urban form despite much current skepticism about its value.

These ideas are considered further beginning with a discussion of the generalizability of the study, followed by theoretical implications, then transportation and land use 
planning and policy implications, and ending with topics which need more research.

\section{GENERALIZABILITY OF STUDY}

As noted in an earlier chapter, Oregon restricts exurban development more than other states. One mechanism for limiting exurban development is the urban growth boundary (UGB). The metropolitan UGB simplified the study by providing a boundary between suburbs and exurbs. In other regions without UGB's, separating exurbia from suburbia would be more complicated. But the UGB and other restrictions on exurban development may have created different exurban residential and commuting patterns in oregon than exist elsewhere. It currently is not possible to draw any definite conclusions about the generalizability of the results to other large metropolitan areas.

We do note, however, that patterns of development in Portland's suburbs and exurbs are not the same. For example, only seven percent of the homes purchased in exurbia were new compared to 24 percent in suburbia. Whether this is due to land use restrictions or other factors such as less speculative building in large lot subdivisions of exurbia is unclear.

The lack of a price jump at the UGB does suggest that rural residential properties have not become scarce enough to command a premium price. Since most exurbanites bought 
lots of less than five acres, lot size restriction do not seem to be limiting people's ability to have an exurban lifestyle if they buy an older home. If demand grows, that could change.

The land use regulations could also be affecting commuting patterns by preventing industry from located in exurbia. This could mean that more oregon exurbanites commute to the urban/suburban core than do in other parts of the country or it could mean there is less demand for exurban living here.

\section{THEORETICAL IMPLICATIONS}

Exurbia lacks a standard definition and a cogent statement of the forces sustaining it. Researchers with urban interests have relied on urban form theory to explain exurban residential growth, while researchers with rural interests have taken a more ad hoc approach. Although the bid-rent model of urban form is more elegant, many question whether it is relevant today (Richardson 1988). Filling in these theoretical gaps is beyond the scope of this study, but some insights have been gleaned.

\section{Exurban Development}

Definition. This study has followed urban field theory and defined exurbia as the region beyond the suburbs but within the commuting range of the city and its suburbs. In the Portland area, "beyond the suburbs" means outside the 
metropolitan urban growth boundary where urban services are not provided. The study found that the commuting range extends about 30 miles from the city center. A few urban and suburban job holders lived farther out. But considering the people surveyed who commute long distances out of the area, extending the exurban boundary to enclose everyone who commutes to Portland or its suburbs could result in some absurd boundaries.

In a review article, Joseph and smit (1981) define exurban development as "residential development in the countryside which is urban-initiated but is physically separate from the urban centre." Urban-initiation requires that households maintain job or other major links with the urban core. That definition would have posed problems for this research and for applying the results to land use and transportation planning. Some rural residential development, especially in the far reaches of exurbia, is small town-initiated. This would mean that some rural residential development, say 25 miles from the city center, would be exurban and some simply rural. Second-home development could also be considered exurban with Joseph and Smit's definition, but it is a separate phenomena. It seems better to use a definition keyed to aggregate behavior, like the proportion of the population who commute to urban/suburban jobs, rather than one based on specific behavior. 
Nonetheless exurban development, at least in the Portland region, is based on definite ties to the urban/suburban core. The core is both the source of the majority of the exurban home purchasers and the place where most of them are employed.

Forces Sustaining Exurban Development. This study has shown that exurbanites are a diverse group of people. But some common factors identified as potential forces sustaining exurban development in the literature review are obviously at work.

The main factors identified by exurbanites themselves are attitudes about where to live and a willingness to commute longer to live in the right place. Exurban home buyers clearly show pro-rural attitudes about the desirable place to live and raise their families. Most do travel longer times and distances to live in a rural place. Interestingly, these desires and actions are similar to those that fostered suburban residential development following World war II.

Although respondents seldom mentioned cost savings as a reason for choosing their location, the analysis shows that many exurbanites do pay less per unit of housing. Thus in return for their longer commutes, exurbanites get both the rural amenities they desire and cheaper housing; especially if they live farther out. This makes is possible to buy more space or to have more funds available for other goods. 
Furthermore, many do not seem to mind the longer commutes. Although it may just be rationalization, exurbanites commented that the drive home through the countryside is relaxing and is a positive aspect of their location. The analysis did show that principal wage earners with the ability to adjust commuting times actually moved farther from work than those who do not have that flexibility.

Low transportation costs are probably a factor influencing the willingness to commute longer distances. Even if commuting has positive aspects, longer commutes require more gasoline and cause more wear-and-tear on vehicles. If exurbanites paid the full social costs of commuting as calculated by Hanson (1989), they would have less income available for housing or other goods. However, this concept was not measured in the study.

The study also shows that the decentralization of employment is a factor influencing exurban development. For Child-Raising households, the type who most often hold decentralized jobs, decentralized employment means commuting no farther than suburbanites. For others decentralized employment does not eliminate longer commutes. Rather it brings more remote rural areas within an acceptable commuting range.

Household income and desires for lower taxes or different public goods and services were found to be only 
weakly related to exurban living. Households of all income levels bought exurban homes, and income had no direct impact on commuting time. Property tax rates and school quality were rarely cited as important reasons for moving to exurbia. Indeed many seemed woefully ignorant of property tax rates, which seems odd in a high property tax state like Oregon. Taxes and school expenditures do, however, influence housing prices; so their impact may be indirect. other public goods like clean air and recreational opportunities were not measured in the study although some households commented on these factors.

Finally, although metropolitan population growth was a factor identified in the literature review as a potential force influencing exurban development, it was not used in this analysis. It should be noted, however, that all the counties in the study area grew between 1980-1987 and that Washington county was the fastest growing county in the state with a growth rate of almost 14 percent (Center for Population Research and Census 1988). Thus population growth could have been a factor influencing the demand for exurban living.

\section{Theory of Urban Form}

Although the bid-rent model of urban form has frequently been criticized for being unrealistic, it was supported by this analysis. Exurban households usually have 
higher transportation costs than suburbanites, but in exchange, pay less for housing.

Furthermore, the model can be used to help explain the behavior of each of the four types of exurban households. The Child-Raising households are the only ones who take full advantage of deconcentrated jobs to live in exurbia without longer commutes than suburbanites. This group differs from small town and suburban home-buyers mainly in their desire for more space. But the combination of family responsibilities and two jobs apparently limits the distances they are willing commute to obtain that space.

All other exurban households must travel farther than suburbanites to live in exurbia. Affluents are seeking both more space and rural amenities not available in the urban/suburban area. They can afford the higher prices for these goods closer to the suburbs than the other groups. Economy-Minded households, on the other hand, appear to ive moving to exurbia to find affordable housing with perhaps a little more space than in the suburbs. This strategy requires longer commutes but frees up more income for other goods. The Long-Distance-Commuters combine both a strong desire for space and rural amenities and a need to economize. They can meet their needs only by moving farther from their jobs. This strategy works for them because most of these households rely on a single wage earner resulting 
in a household commuting budget that is about the same as in most two-wage earner households.

\section{PLANNING AND POLICY IMPLICATIONS}

Some households are willing to commute longer distances to live in a low-density, rural setting. These households are unlikely to be influenced by efforts to encourage compact, dense settlements whether those efforts are urban growth boundaries, public transportation investments, encouragement of housing close to suburban work locations, or other measures. As long as rural housing and longer commuting is affordable, some households will want to live in exurbia.

\section{Transportation Planning and Policy}

If more households move to exurbia, they will put more traffic on county roads and on highways leading into the urban/suburban area. Although exurbanites have some complaints about the quality of county roads, they do not complain of exurban congestion. Rather it is in suburbia that the congested roads are found. Because most exurbanites commute into or through the suburbs, they are part of suburban transportation problems. More exurbanites will only exacerbate current problems.

If light rail lines or new highways are built to solve the problems they might encourage more exurban growth which could lead to future congestion if not adequately considered 
in the planning process. For example, light rail lines with suburban park-and-ride stations might make it easier to get from exurbia to jobs in downtown Portland. Freeway bypasses might improve accessibility of exurban areas to suburban jobs and also increase the demand for rural living. Thus transportation planners and policy makers need to consider both current problems and potential future needs when planning changes in transportation systems.

When making projections of the impacts of future projects, planners need to rely on sound information which has previously been lacking. Not only should outdated thinking about commuting be avoided, as Pisarski (1987) points out, but simple assumptions need to be checked with reality. For example, previous research suggested that exurban lifestyles would not be attractive to two-wageearner households. Yet, they turned out to be most prevalent in exurbia.

\section{Land Use Planning and Policy}

Because oregon's statewide land use planning goals emphasize preserving agriculture and forest lands and directing urban development to land inside urban growth boundaries, rural residential development has been restricted more than in the other 48 contiguous states. Exurban development is considered an "exception" and a variance is required for new home construction. New exurban lots are generally required to be 5,10 , or 20 acres in 
size. Furthermore, rural residential development is allowed only in areas with low resource potential or with existing rural residential development (Leonard 1983).

A difficult balancing act is required in exurban land use planning. Preservation of resource. lands needs to be balanced with accommodating people's desires for rural iffestyles. Providing affordable housing needs to be balanced with maintaining the rural attributes which attracted exurban residents in the first place. Planning for future urban expansion needs to be balanced with serving today's needs.

In Oregon the emphasis of the exurban planning process has been on avoiding unwise development. Now that those plans are in effect, more attention should be given to methods for wisely accommodating people's desires for exurban living. Though most exurban home buyers want larger lots, they do not necessarily want lots of 5 acres or more. Indeed, most purchased less than 5 acres in 1987. Some do want acreage for part-time agricultural pursuits, but many simply want the rural setting. Planned unit developments which cluster housing while preserving open space in common ownership might better serve the needs of many exurbanites. other possibilities include land trusts or conservation easements to preserve open space and resource land while requiring more compact rural residential areas (Peirce 1989). Clustered development might also make it easier to 
provide police and fire protection, mail delivery, school bus transportation, and other services.

Furthermore thought should be given to accommodating the diverse types of people who desire rural living. Even very low income households bought exurban homes. But by requiring large lots, they might be excluded from the market. Certainly they would no longer qualify for the Farmer's Home Administration rural housing program which limits lots to one acre or less. The need for low income housing as well as conflicts in different governmental programs with valid but different objectives should be addressed.

The locational preferences of exurban household types also creates a land use planning dilemma. Affluent households, who have strong desires to live in a rural area and probably the most expertise and clout to fight change, tend to live nearest the urban area. This could make expansion of the urban area difficult. One solution would be to provide a buffer zone of resource land between the urban growth boundary and rural residential areas. But in many parts of the Portland region this buffer does not exist.

Other parts of the country planning growth management strategies can learn from the oregon experience. Restricting unwise development which erodes the resource base and creates demands for expensive public infrastructure 
is important. But thought also needs to be given to appropriate ways of allowing rural living near cities.

\section{RESEARCH NEEDS}

Clearly the greatest need is for more studies on exurban development and commuting patterns in other places These studies would determine whether the results of this case study are unique to oregon or generally applicable.

\section{Exurban Development}

The study has raised some questions about exurban development which need further research. First, are longterm exurban residents like recent exurban home buyers or more like small town residents? In other words, is the picture of exurban residents developed in this study a snapshot of exurbia today or is it a picture of what exurbia is becoming? Second, does the large proportion of families with chilaren moving to exurbia mean that the desire for exurban living is largely a babyboomer phenomena which will subside as that generation ages? The survey did not ask for people's ages, so the proportion of exurban families who are members of that generation is unknown. Both of these issues are important for determining the long-term trends in exurban development.

The typology of exurbanites would also benefit from further study. Do the same household types exist in other exurban areas? How do the factors which influence the 
commuting behavior of all exurbanites influence behavior for each household type? (The groups were too small to produce meaningful regression results for each type in this study.) Would additional data on age of household members and homeownership before the move provide new insights? Are exurban household types similar to or different from suburban household types today and in the past? If the exurban household types resemble those who moved to suburbia in the 1950's, that might indicate that exurban development today is much like suburban development of an earlier era.

Another area worth further analysis is the exurban housing market and the ways it differs from the suburban housing market. This was only partially analyzed in the study and some variables produced puzzling results. Furthermore additional analysis on the exurban housing market could be done with data from this survey plus some additional secondary data. For example, the impacts of living close to the urban growth boundary or the influences of suburban job centers on housing prices could be examined with the addition of appropriate distance variables.

\section{Commuting Behavior}

Several of the factors which influenced commuting time could use additional research. The interpretation of the regression results required making some assumptions about the underlying attitudes and beliefs which might yave produced the indicated behavior. It would be useful to know 
more specifically about these underlying attitudes and beliefs to avoid drawing the wrong conclusions.

One area where such research is needed is the dynamics of two-wage-earner households. Even though they have been a focus of recent commuting research, there complex nature is only partially understood. Studies need to look deeper than demographic characteristics and commuting times. More information is needed on the home and work roles of members of two-wage-earner households and their attitudes about work, home, and commuting.

Another area needing additional research is occupation and commuting where amazingly little research has been done. Some means of sejarating the two aspects of occupational influence--attitudes towards commuting and the spatial structure of a region--is needed. One possibility is the use of a national data set such as the American Housing Survey or the 1990 Census to clarify which occupational groups are willing to travel more than others. If commuting patterns of occupational groups were consistent in many metropolitan areas, that would indicate a willingness to commute. A large data set would also allow finer occupational distinctions than were used in this study. That could improve results since the occupation groups used here were not homogeneous with respect to commuting. Another potential type of research on this issue is survey 
research to clarify how occupation and attitudes towards commuting are related.

Surveys on attitudes toward commuting are also needed to clarify the positive aspects of commuting. Home-work separation, zones of indifference, and commuting as leisure could all benefit from further study. This was only hinted at in this study with a measure of scenic attributes of the commute and comments on the relaxing nature of the rural drive.

\section{CONCLUSIONS}

Many Americans desire a rural lifestyle even though they hold urban and suburban jobs. Many are acting on that desire and moving to exurban homes. Although these moves often require longer commutes, the decision is economically rational since housing prices are cheaper and the desired rural amenities are available. Despite the fears of some planners and researchers that this type of low density development is bad for society, people can be expected to continue to follow their individual aspirations. The challenge is to determine how to best accommodate people's desires for exurban living without incurring undue social costs. 
REFERENCES

Alonso, w. 1960. A theory of the urban land market. Papers and Proceedings of the Regional science Association 6: 149-157.

Alonso, w. 1964. Location and Land Use. Cambridge: Harvard University Press.

Alonso, w. 1978. The current halt in metropolitan phenomenon. In The mature metropolis, ed. C.L. Leven, 23-41. Lexington, MA: Lexington Books.

Anas, A. and L.N. Moses. 1978. Transportation and land use in the mature metropolis. In The mature metropolis, ed. C.L. Leven, 149-168. Lexington, MA: Lexington Books.

Beesley, M.E. and M.Q. Dalvi. 1974. Spatial equilibrium and journey to work. Journal of Transport Economics and Policy, 8: 197-222.

Bell, D. 1974. The coming of the post-industrial society. New York: Basic Books.

Berry, B.J.L. and Q. Gillard. 1977. The changing shape of metropolitan America: commuting patterns, urban fields and decentralization processes, 1960-1970. Cambridge, MA: Ballinger Publishing Co.

Bureau of Census. 1984. 1980 Census of Population. Journey to Work - Metropolitan commuting flows. Washington, D.C.: U.S. Government Printing office.

Burgess, E.W. 1925. The Growth of the city. In The city, ed. R.E. Park, E.W. Burgess, and R.A. McKenzie, Chicago: University of Chicago Press.

Carlino, G.A. 1985. Declining city productivity and the growth of rural regions: a test of alternative explanations. Journal of Urban Economics, 18: 11-27.

Center for Population Research and Census. 1988. official population estimates for oregon counties and cities, July 1, 1978-July 1,1987. Portland, OR: Portland State University. 
Cervero, R. 1986. Suburban gridlock. New Brunswick, N.J.: Center for Urban Policy Research.

Clark, W.A.V. and J.E. Burt. 1980. The impact of workplace on residential location. Annals of the Association of American Geographers 70(1): 59-67

Clawson, M. 1971. Suburban Land Conversion in the U,S. Baltimore: The Johns Hopkins Press.

Coleman, J.S. 1978. Social processes and social policy in the stable metropolis. In The mature metropolis, ed. C.L. Leven, 43-62. Lexington, MA: Lexington Books.

Cubukgil, A. and E.J. Miller. 1982. Occupational status and the journey-to-work. Transportation, 11: 251-276.

Dillman, D.A. 1978. Mail and telephone surveys: the total design method. New York: John Wiley and Sons.

Doherty, J.C. 1984. Growth management in countrified cities. Alexandria, VA: Vert Milon Press.

Dueker, K.J., J.G. Strathman, I.P. Levin and A.G. Phipps. 1983. Rural residential development within

metropolitan areas. Computers. Environment and Urban Systems $8(2): 121-129$.

Elazar, D.J. 1987. Building cities in America: urbanization and suburbanization in a frontier society. Lanham, MD: Hamilton Press.

Evans, A.W. 1973. The economics of residential location. London: MacMillan.

Fisher, J.S. and R.L. Mitchelson. 1981. Extended and internal commuting in the transformation of the intermetropolitan periphery. Economic Geography 57(3): 189-207.

Flaim, P.O. 1986. Work schedules of Americans: an overview of new findings. Monthly Labor Review, 109 (Nov.): 3-6.

Frey, W.H. 1987 Migration and depopulation of the metropolis: regional restructuring or rural renaissance? American Sociological Review, 52: 240257.

Friedmann, J. and J. Miller. 1965. The urban field. Journal of the American Institute of Planners 31: 312320 . 
Fuguitt, G.V. and P.R. Voss. 1979. Growth and change in rural America. Washington, D.C.: The Urban Land Institute.

Fulton, P.N. 1986. Changing journey-to-work patterns: The increasing prevalence of commuting within the suburbs in metropolitan America. Paper presented at the 1986 Annual Meeting of the Transportation Research Board.

Gera, S. and P. Kuhn. 1981. Occupation and the journey-towork: some further analysis. Socio-economic Planning Sciences, 15: 83-93.

Getis, A. 1969. Residential location and the journey from work. Proceedings of the Association of American Geographers, 1:55-59.

Gordon, P., A. Kumar and H.W. Richardson. 1989. Congestion, changing metropolitan structure, and city size in the United States. International Regional Science Review, 12: 45-56.

Halvorson, Peter L. 1975. The critical isochrone: an alternative definition. Proceedings of the Association of American Geographers, 7: 84-85.

Hanson, M.E. 1989. Automobile subsidies, land use, and transportation policy. Madison, WI.: Department of Urban and Regional Planning and Institute for Environmental studies, mimeo.

Healy, R.G. and J.I. Short. 1981. The market for rural land. Washington, D.C.: Conservation Foundation.

Herbers, J. 1986. The new heartland: America's flight beyond the suburbs and how it is changing our future. New York: Timesbooks.

Horvath, F.W. 1986. Work at home: new findings from the Current Population Survey. Monthly Labor Review, 109 (Nov.): $31-35$.

Howland, L. 1982. Communications technology: Shifting the work place. Urban Land 41 (October): 22-23.

Hoyt, H. 1939. The structure and growth of residential neighbourhoods in American cities. Washington,D.C.: U.S. Government Printing office.

Hutchinson, B.G. 1986. Structural changes in commuting in the Toronto region 1971-1981. Transport Reviews, 6: 311-329. 
Jackson, K.T. 1985. Crabgrass frontier: The suburbanization of the United States. New York: Oxford University Press.

Joseph, A. and B. Smit. 1981. Implications of exurban residential development: A review. The Canadian Journal of Regional Science $4(2)$ : 207-224.

Joseph, A. and B. Smit. 1983. Preferences for publicservice provision in rural areas undergoing exurban residential development--a Canadian view. Tijdschrift voor Economische en sociale Geografie $74(1): 41-52$.

Kain, J.F. 1962. Journey-to-work as a determinant of residential location. Papers and proceedings of the Regional Science Association 9: 137-160.

Kasarda, J.D. 1983. The implications of contemporary redistribution trends for national urban policy. In Transition to the 21st century: Prospects and policies for economic and urban-regional transformation, ed. D.A. Hicks and N.J. Glickman, 17-47. Greenwich, CN: JAI Press.

Kasper, H. 1983. Toward estimating the incidence of journey-to-work costs. Urban studies, 20: 197-208.

Kutscher, R.E. and V.A. Personick. 1986. Deindustrialization and the shift to services. Monthly Labor Review, 109 (June): 3-13.

Lamb, R.F. 1983. The extent and form of exurban sprawl. Growth and change 14(1): 40-47.

Leonard, H.J. 1983. Managing Oregon's growth: The politics of development planning. Washington, D.C.: The Conservation Foundation.

Lessinger, J. 1986. Regions of opportunity. New York: Timesbooks.

Leven, C.L. 1979. Economic maturity and metropolis evolving physical form. In The changing structure of the city, ed. G.A. Tobin, 21-44. Vol. 16 of Urban affairs annual reviews. Beverly Hills: Sage.

Madden, J.F. 1981. Why women work closer to home. Urban Studies, 18: 181-194.

Mellor, E.F. 1986. Shift work and flexitime: how prevalent are they? Konthly Labor Review: 109 (Nov.): 14-21. 
Mitchelson, R.L. and J.S. Fisher. 1981. Commuting cost visibility: a contemporary case study. Southeastern Geography, 21(2): 130-147.

Muller, P.O. 1981. Contemporary suburban America. Englewood cliffs, N.J.: Prentice Hall.

Muth, R. 1969. Cities and Housing. Chicago: University of Chicago Press.

Nelson, A.C. 1988. An empirical note on how regional urban containment policy influences an interaction between greenbelt and exurban land markets. Journal of the American Planning Association, Spring: 178-184.

Nelson, A.C. and K.J. Dueker. (forthcoming) The planning implications of improving property service technology or severing the urban umbilical cord. Journal of Planning Education and Research.

Oates, W.E. 1969. The effects of property taxes and local public spending on property values: an empirical study of tax capitalization and the Tiebout hypothesis. Journal of Political Economy, 77: 957-971.

Office of Federal statistical Policy and Standards. 1980. Standard occupation classification manual, 2nd ed. Washington, D.C.: U.S. Government Printing Office.

Peirce, N.R. 1989. Saving our national heritage: New planning design may satisfy ecology and growth in Puget Sound. oregonian. October 22.

Pisarski, A.E. 1987. Commuting in America. Westport, CN: Eno Foundation for Transportation, Inc.

Price, L.W., ed. 1987. Portland's changing landscape. Portland, OR: Portland State University.

Richter, K. 1985. Nonmetropolitan growth in the late 1970's: the end of the turnaround? Demography, 22(2): 245-263.

Richardson, H.W. 1988. Monocentric vs. polycentric models: The future of urban economics in regional science. The Annals of Regional Science, 22:1-12.

Roberts, R. 1986. Analysis of demographic trends and travel pattern: Implications for the future of the Portland Transit Market. In Transportation Research Record 1067, 1-8. Washington, D.C.: Transportation Research Board. 
Salomon I. and M. Salomon. 1984. Telecommuting: the employees perspective. Journal of Technological Forecasting and Social change, 25(1): 15-28.

Singell, I.D. and J. H. Lillydahl. 1986. An empirical analysis of the commute to work patterns of males and females in two-earner households. Urban studies 23(2): 119-129.

Spectorsky, A.C. 1955. The exurbanites. Philadelphia: J.B. Lippincott Co.

Stevens, J.B. 1980. The demand for public goods as a factor in the nonmetropolitan migration turnaround. In New difections in urban-rural migration, ed. D.L. Brown and J.M. Wardwell, 115-134. New York: Academic Press.

Taaffe, E.J., H.I. Gauthier, and T.A. Maraffa. 1980. Extended commuting and the intermetropolitan periphery. Annals of the Association of American Geographers $70(3): 313-329$.

Tiebout, C.M. 1956. A pure theory of local expenditures. Journal of Political Economy 64: 416-424.

Troughton, M. 1981. Aspects of employment and commuting in the fringe zone of London, Ontario. In The Rural-urban fringe: Canadian perspectives, ed. K.B. Beesley and L.H. Russwurm, 144-178. Geographical Monographs, No. 10. Downsview, Ontario: York University.

Wardwell, J.M. 1980. Toward a theory of urban-rural migration in the developed world. In New directions in urban-rural migration, ed. D.L. Brown and J.M. Wardwel1, 71-114. New York: Academic Press.

White, M.J. 1986. Sex differences in urban commuting patterns. American Economic Review, 76(2): 368-372.

White, M.J. 1988. Urban commuting journeys are not "wasteful". Journal of Political Economy, 96:10971110 .

Wilkinson, L. 1988. SYSTAT: The system for statistics. Evanston, IL: SYSTAT, Inc.

Williams, J.D. and A. J. Sofranko. 1979. Motivations rur the in-migration component of population turnaround in nonmetropolitan America. Demography 16: 239-255. 
Yamada, H. 1972. On the theory of residential location: Accessibility, space leisure and environmental quality. Papers of the Regional Science Association 29: 125-135.

zelinsky, w. 1977. Coping with the migration turnaround: The theoretical challenge. International Regional Science Review 2(2): 175-178.

Zimmer, B.G. 1985. Metropolitan development and the changing journey to work. Social science Quarterly $66(3): 519-532$.

Zuiches, J.J. 1981. Residential preferences in the United states. In Nonmetropolitan America in transition, ed. A.H. Hawley and S.M. Mazie, 72-115. Chapel Hill: University of North Carolina Press. 
APPENDIX A

SURVEY INSTRUMENT AND COVER LETTERS 


\section{PLANNING TRANSPORTATION TO SERVE}

\section{SUBURBAN, SMALL TOWN AND RURAL RESIDENTS}

A survey of households who purchased

homes near Portland, Oregon, in 1987

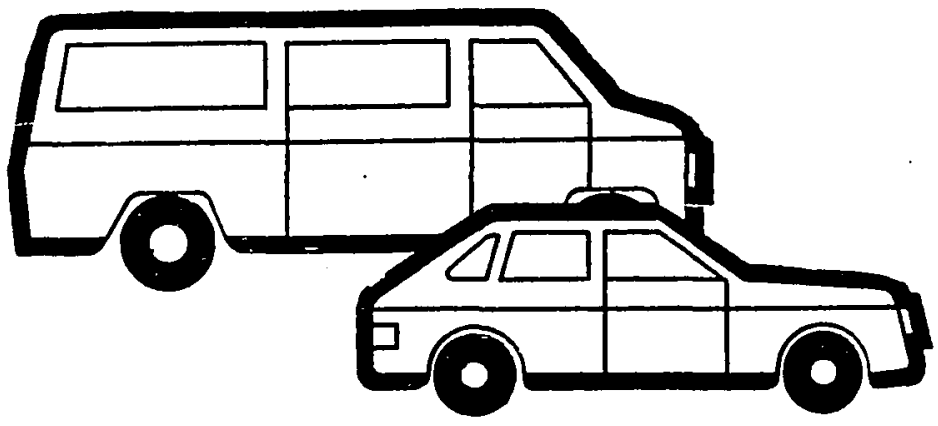

Please return this questionnaire to:

Center for Urban Studies

Portland State University

P.O. Box 751

Portland, Oregon 97207 
Please answer all questions as directed. If you wish to comment on any question, feel free to $w$ rite in the margins or ase the space on the back cover. Thank you for your help.

1. When you moved to this house, what were the THREE most important reasons for your move? (Please circle the numbers of the THREE most important reasons.)

1 New job or job transfer

2 Retirement

3 To be closer to work

4 To be farther from work

5 Married, widowed, divorced, or separated

6 Wanted better place to raise our family

7 Other family or personal reasons

8 Former neighborhood was changing

9 Wanted better quality house

10 Wanted different size house

11 Wanted less expensive house

12 Wanted to own instead of rent

13 Wanted large lot or acreage

14 Wanted to live in more rural area

15 Wanted to live in more urban area

16 Wanted bet:er schools

17 Wanted lower taxes

18 Other (please tell us):

If neighborhood change was a main reason for moving, how was your neighborhood changing? (circle numbers of $A L L$ that apply)

1 More people living there

2 More traffic

3 More crime

4 Different type of people

5 Other

(please describe)

2. What were the THREE most important reasons for chocsing this particular neighborhood? (Please circle the numbers of the THREE most important reasons.)

1 Convenient to job

2 Close to friends or relatives

3 Close to parks/recreation

$4 \quad$ Availability of public transit

5 Access to freeways/major highways

6 Good schools

7 Quality of public services

8 Looks/design of neighborhood

9 People who live here are like us

10 Near shopping

11 Best or most affordable house located here

12 Other (please tell us): 
Another important purpose of this study is to learn about the jobs and travel to work of recent movers. Therefore, we would like to ask some questions about the PRINCIPAL WAGE BARNER (the person who earns the most income) and his or her SPOUSB or OTHBR ADULT member of the household, if any. Please ans.rer the firstanestion in both colmmnseren if noone in zon honsehold is employed or travels towork.

About the PRINCIPAL WAGE EARNER

1. Is the principal wage earner employed? (circle number)

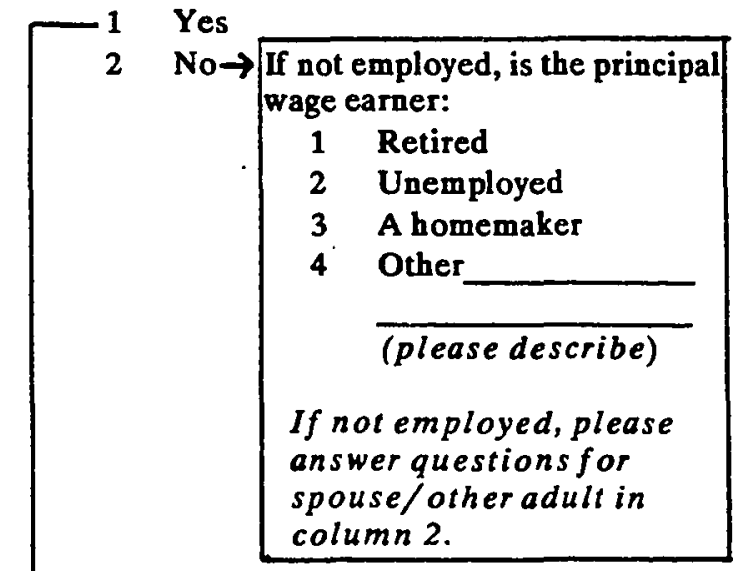

$\rightarrow$ If employed,

2. Does the principal wage earner work at a location away from home? (circle number)

\begin{tabular}{|ll|l|l|l}
1 & Yes & No $\rightarrow$ & $\begin{array}{l}\text { If works at home, please } \\
\text { answer questions for } \\
\text { spouse/otheradult in } \\
\text { column 2. If neither } \\
\text { person works away from } \\
\text { home, skip to page } 9 .\end{array}$ \\
\hline
\end{tabular}

$\rightarrow$ If works away from home,

3. How many minutes does it usually take for the principal wage earner to travel to work? minutes/one-way trip
About the SPOUSE/OTHER ADULT (If none, check here and skip this column.)

1. Is the spouse/other adult employed? (circle number)

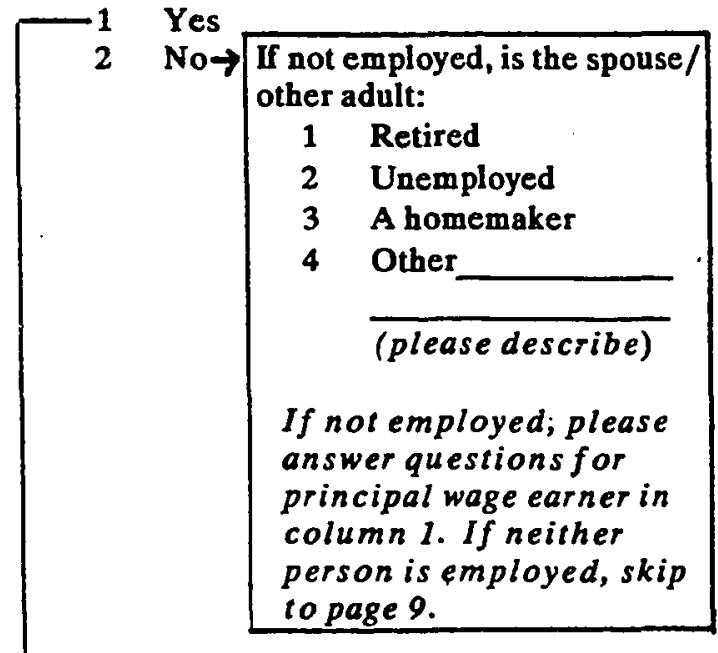

$\rightarrow$ If employed,

2. Does the spouse/other adult work at a location away from home? (circle number)

\begin{tabular}{|c|c|c|}
\hline 2 & $\mathrm{No}_{\mathrm{o}} \rightarrow$ & $\begin{array}{l}\text { If works at home, please } \\
\text { answer questions for } \\
\text { principal wage earner in } \\
\text { column I. If neither } \\
\text { person works away from } \\
\text { home, skip to page } 9 .\end{array}$ \\
\hline
\end{tabular}

$\rightarrow$ If works away from home,

3. How many minutes does it usually take for the spouse/other adult to travel to work? minutes/one-way trip 
Please continue answering questions in this column if the PRINCIPAL WAGE EARNER travels to work.

4. How many miles does the principal wage earner usually travel to work? miles/one-way trip

5. How many days per week does the principal wage earner usually travel to and from work?

$$
\text { days/week }
$$

6. How many hours per week does the principal wage earner usually work?

$$
\text { hours/week }
$$

7. What time does the principal wage earner usually leave home to go to work? (please circle one number)

1 Before 7:30 a.m.

2 Between 7:30 and 9:00 a.m.

3 After 9 a.m.

4 Time varies

8. What time does the principal wage earner usually leave work to go home? (circle a number)

1 Before 4 p.m.

2 Between 4 and 6 p.m.

3 After 6 p.m.

4 Time varies

9. What is the principal wage earner's main mode of travel to and from work? (circle a number)

1 Drives alone

2 Drives or rides in a carpool, vanpool, or ride-share

3 Rides the bus (including park-andride)

4 Other mode of travel
Please continue answering questions in this column if the SPOUSE/OTHER ADULT travels to work.

4. How many miles does the spouse/other adult usually travel to work? miles/one-way trip

5. How many days per wieck does the spouse/ other adult usually travel to and from work? days/week

6. How many hours per week does the spouse/other adult usually work?

hours/week

7. What time does the spouse/other adult usually leave home to go to work? (please circle one number)

1 Before 7:30 a.m.

2 Between 7:30 and 9:00 a.m.

3 After 9 a.m.

4 Time varies

8. What time does the spouse/other adult usually leave work to go home? (circle a number)

1 Before 4 p.m.

2 Between 4 and 6 p.m.

3 After 6 p.m.

4 Time varies

9. What is the spouse/other adult's main mode of travel to and from work? (circle a number)

1 Drives alone

2 Drives or rides in a carpool, vanpool, or ride-share

3 Rides the bus (including park-andride)

4 Other mode of travel 
Please continue answering questions in this column if the PRINCJPAL WAGE EARNER travels to work.

10. During a typical week, what types.of stops does the principal wage earner make on the way to or from work? (Please circle the numbers of $A L L$ that apply.)

1 Drop off or pick up other household members at daycare, school, or other activities.

2 Shop

3 Do personal business (bank, doctor, paircut, etc.)

4 Visit friends or relatives

5 Eat at restaurant

6 Recreation

7 Other (p!ease describe)

8 Does not make stops on the way to or from work

11. Does the principal wage earner use new technologies such as cellular phones to do work while traveling to and from work?

1 Yes $\rightarrow$ Please explain

2 No

12. Does the principal wage sarner's workplace have flextime or some other schedule that allows varying the time to begin and end work? (Circle a number)

1 Yes $\rightarrow$ If yes, does the principal wage earner use flextime to avoid some or all of rush hour traffic?

$$
\begin{array}{ll}
1 & \text { Yes } \\
2 & \text { No } \\
\hline
\end{array}
$$

2 No

13. Does the principal wage earner usually report to the same location to begin work each day?

1 Yes

2 No
Please continue answering questions in this column if the SPOUSE/OTHER ADULT travels to work.

10. During a typical week, what types of stops does the spouse/other adult make on the way to or from work? (Please circle the numbers of $A L L$ that apply.)

1 Drop off or pick up other household members at daycare, school, or other activities.

2 Shop

3 Do personal business (bank, doctor, haircut, etc.)

4 Visit friends or relatives

5 Eat at restaurant

6 Recreation

7 Other

8 Does not make stops on the way to or from work.

11. Does the spouse/other adult use new technologies such as cellular phones to do work while traveling to and from work?

1 Yes $\rightarrow$ Please explain

\section{No}

12. Does the spouse/other adult's workplace have flextime or some other schedule that allows varying the time to begin and end work? (Circle a number)

$1 \quad$ Yes $\rightarrow\left[\begin{array}{ll}\text { If yes, does the spouse/other } \\ \text { adult use flextime to avoid } \\ \text { some or all of rush hour traffic? } \\ 1 & \text { Yes } \\ 2 & \text { No }\end{array}\right.$

2 No

13. Does the spouse/other adult usually report to the same location to begin work each day?

1 Yes

2 No 
Please continue answering questions in this column if the PRINCIPAL WAGE EARNER travels to work.

14. Does the principal wage earner usually spend most working hours at the same place? (circle a number)

1 Yes

2 No

15. Does the principal wage earner work at the same job location as before moving? (circle $a$ number)

1 Yes

2 No, changed job locations along with moving

3 No, changed job locations since moving

16. Is the principal wage earner selfemployed?

1 Yes

2 No

17. Is the principal wage earner's work:
1 Full-time?
2 Part-time?
3 On call?

18. Does the principal wage earner work:
1 Days?
2 Evenings?
3 Nights?
4 Rotating shifts?
5 Other schedule?

19. Does the principal wage earner usually work on Saturdays or Sundays?

$\begin{array}{ll}1 & \text { Yes } \\ 2 & \text { No }\end{array}$

20. What is ZIP code of the principal wage earner's workplace?

ZIP Code
Please continue answering questions in this column if the SPOUSE/OTHER ADULT travels to work.

14. Does the spouse/other adult usually spend most working hours at the same place?

(circle a number)

1 Yes

2 No

15. Does the spouse/other adult work at the same job location as before moving? (circle a number)

1 Yes

2 No, changed job locations along with moving

3 No, changed job locations since moving

16. Is the spouse/other adult self-employed?

$$
\begin{array}{ll}
1 & \text { Yes } \\
2 & \text { No }
\end{array}
$$

17. Is the spouse/other adult's work:
1 Full-time?
2 Part-time?
3 On call?

18. Does the spouse/other adult work:
1 Days?
2 Evenings?
3 Nights?
$4 \quad$ Rotating shifts?
5 Other schedule?

19. Does the spouse/other adult usually work on Saturdays or Sundays?

$$
\begin{array}{ll}
1 & \text { Yes } \\
2 & \text { No }
\end{array}
$$

20. What is ZIP code of the spouse/other adult's workplace? ZIP Code 
Please continue answering questions in this column if the PRINCIPAL WAGE EARNER travels to work.

21. Does the principal wage earner do any regularly scheduled work for his or her principal employer at home. (circle number)

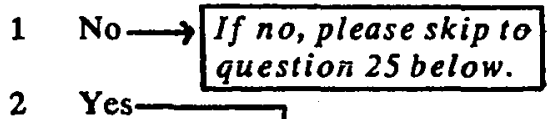

If some work is done at home,

22. About how many hours per week are spent working at home? hours/week

23. Does working at home reduce the number of trips to work each week?

(circle number)

1 Yes

2 No

24. When working at home, does the principal wage earner communicate with co-workers or customers by: (circle the numbers of $A L L$ that apply.)

1 Telephone

2 Electronic mail

3 Regular mail

4 Facsimile machine

5 Other

(please describe)

6 Does not communicate with co-workers or customers when working at home.

25. Please think about travel to work from your former residence. Before you moved, how far did the principal wage earner travel to work?

AND miles/one-way trip
Please continue an whering que stions in this column if the SPOUSE/OTHER ADLLT travels to work.

21. Does the spouse/other adult do any regularly scheduled work for his or her principal employer at home. (circle number)

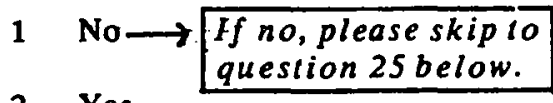

2 If some work is done at home,

22. About how many hours per week are spent working at home? hours/week

23. Does working at home reduce the number of trips to work each week? (circle number)

1 Yes

2 No

24. When working at home, does the spouse/other adult communicate with co-workers or customers by: (circle the numbers of ALL that apply.)

1 Telephone

2 Electronic mail

3 Regular mail

4 Facsimile machine

5 Other please describe

6 Does not communicate with co-workers or customers when working at home.

25. Please think about travel to work f rom your former residence. Before you moved, how far did the spouse/ other adult travel to work? miles/one-way trip

AND minutes/one-way trip 
if you have been answering questions about the PRINCIPAL WAGE EARNER who travels to work, please answer question 26. Otherwise skip to question 27.

26. Is the principal wage earner's travel to and from work at this house different from the travel to and from work at the former residence? For each characteristic listed below, please indicate how the principal wage earner's travel to work has changed or if it is the same. For example, if the distance is longer now, circle MORE after the word "Miles".

\begin{tabular}{|c|c|c|c|c|}
\hline \multirow[b]{2}{*}{ a. } & \multirow{2}{*}{ Miles ............................ MORE } & \multicolumn{3}{|c|}{$\begin{array}{c}\text { Compare present travel to work with former } \\
\text { please circle your answer }\end{array}$} \\
\hline & & LESS & SAME & DON'T KNOW \\
\hline b. & Minutes ................................. MORE & LESS & SAME & DON'T KNOW \\
\hline c. & Trips each week. & LESS & SAME & DON'T KNOW \\
\hline d. & Use of public transit................. MORE & LESS & SAME & DON'T KNOW \\
\hline e. & Carpooling or ride-sharing ....... MORE & LESS & SAME & DON'T KNOW \\
\hline 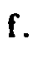 & Number of stops on way............ MORE & LESS & SAME & DON'T KNOW \\
\hline g. & Amount of congestion...............MORE & LESS & SAME & DON'T KNOW \\
\hline 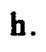 & Speed of travel ........................FASTER & SLOWER & SAME & DON'T KNOW \\
\hline & Road conditions ..................... BETTER & WORSE & SAME & DON'T KNOW \\
\hline & Scenery along route ................ BETTER & WORSE & SAME & DON'T KNOW \\
\hline
\end{tabular}

If you have been answering questions about the SPOUSE/OTHER ADULT who travels to work, please answer question 27. Otherwise go to the next page.

27. Is the spouse/other adult's travel to and from work at this house different from the travel to and from work at the former residence? For each characteristic listed below, please indicate how the spouse/other adult's travel to work has changed or if it is the same. For example, if the distance is longer now, circle MORE after the word "Miles".

$$
\begin{gathered}
\text { Compare present travel to work with former } \\
\text { please circle your answer }
\end{gathered}
$$
a. Miles
LESS
SAME
DON'T KNOW
b. Minutes
LESS
SAME
DON'T KNOW
c. Trips each week
MORE
L.ESS
SAME
DON'T KNOW
d. Use of public transit MORE
LESS
SAME
DON'T KNOW
e. Carpooling or ride-sharing ...... MORE
f. Number of stops on way ........... MORE
LESS
SAME
DON'T KNOW
g. Amount of congestion.
LESS
SAME
DON'T KNOW
h. Speed of travel
MORE
LESS
SAME
DON'T KNOW
i. Road conditions . FASTER
SLOWER
SAME
DON'T KNOW
j. Scenery along route BETTER
WORSE
SAME
DON'T KNOW
WORSE SAME
DON'T KNOW 
All home purchasers, please continue answering questions here.

Nert, we would like ask some questions about your new home and your household to help interpret the reselts.

1. How many rooms (not counting bathrooms) does your house have?

rooms

2. How many bathrooms?

bathrooms

3. How large is your lot?

square feet

OR feet by feet.

OR acres

4. How large is your house? square feet of living space

5. About how old is your home? years

6. Is your home a: (please circle a number)

1 Condominium?

2 Mobile home?

3 Standard single-family house?

7. What is your main source of household water? (circle a number)

1 City or public water district

2 Private water system with more than one user

3 Own well

4 Other (please describe)
8. What is your means of sewage disposal?

1 Public sewer system hookup

2 Septic tank or cesspool

3 Other

(please describe)

9. Do you have a garage?

1 Yes

2 No

10. How many adults (age 18 or older) usually live here? adults

11. How many children (under age 18) usually live here? children

12. How many members of your housebrld are licensed drivers ?

$$
\text { licensed drivers }
$$

13. How many cars, light trucks, and vans are normally kept at your house?

$$
\text { cars, light trucks and vans }
$$

14. What is the Zip code of your home address?

$$
\text { Zip code }
$$

15. Where was your former bome? city state Zip code 
16. Which category best describes your household's annual income? (Circle number)

$\begin{array}{ll}1 & \text { Less than } \$ 20,000 \\ 2 & \$ 20,000-\$ 29,999 \\ 3 & \$ 30,000-\$ 39,999 \\ 4 & \$ 40,000-\$ 49,999 \\ 5 & \$ 50,000-\$ 59,999 \\ 6 & \$ 60,000-\$ 69,999 \\ 7 & \$ 70,000-\$ 79,999 \\ 8 & \$ 80,000-\$ 89,999 \\ 9 & \$ 90,000-\$ 99,999 \\ 10 & \text { More than } \$ 100,000\end{array}$

Finally, we would like to ask a few questions about the PRINCIPAL WAGE EARNER and his or her SPOUSE or OTHER ADULT member of the household. Please answer the questions in both columns if there are two adults in the household.

About the PRINCIPAL WAGE EARNER

17. Is the principal wage earner:

$$
\begin{array}{ll}
1 & \text { Male? } \\
2 & \text { Female? }
\end{array}
$$

18. What is the highest level of education that the principal wage earner has completed?

(Circle one number)

1 No formal education

2 Some grade school

3 Completed grade school

4 Some high school

5 Completed high school

6 Some college

7 Completed college

8 Graduate school

19. What is the occupation of the principal wage earner? (If retired, please describe the usual occupation bef ore retirement.)

Kind of work:

Kind of company or workplace:
About the SPOUSE/OTHER ADULT, if any

17. Is the spouse/other adult:

$$
\begin{array}{ll}
1 & \text { Male? } \\
2 & \text { Female? }
\end{array}
$$

18. What is the highest level of education that the spouse/other adult has completed?

$$
\text { (Circle one number) }
$$

1 No formal education

2 Some grade school

3 Completed grade school

4 Some high school

5 Completed high school

6 Some college

7 Completed college

8 Graduate school

19. What is the occupation of the spouse/other adult? (If retired, please describe the usual occupation before retirement.)

Kind of work:

Kind of company or workplace:

Thank you for completing this questionnaire. Any additional comments may be written on the back cover. 
Is there anything else you would like to tell us about your recent move and your travel to work? If so, please use this space for that purpose. 
February 23, 1989

NAME

\section{ADDRESS}

CITY, Oregon ZIP

Dear NAME:

As both people and jobs have moved to the suburbs, small towns and countryside near cities, traffic patterns have changed. Roads which used to have light traffic are now congested. Fewer people ride buses. Rush hour traffic goes in all directions. Clearly, changes in bighway and transit systems are needed. But any changes will be costly and long lasting. Thus it is important to develop transportation systems that not only solve the problems of today but also meet the needs of the future. To do this, more information is needed about why people, like you, choose to live near cities and how this affects travel to work.

Your household is one of a small number being asked about these matters. You were selected in a random sample of recent home purchasers in the Portland metropolitan area. It is important that each questionnaire be completed and returned in order for the results to represent the experience of all home purchasers in the region. The questionnaire may be completed by any adult household member who knows about your reasons for moving and the travel to work of the household members. It should only take about fifteen to twenty minutes to complete.

You may be assured of confidentiality. The questionnaire has an identification number so that your name may be checked off the mailing list when your questionnaire is returned. Your name will never be placed on the questionnaire nor used for any other purpose.

The results of this study will be made available to transportation policy makers, planners, and researchers. You may receive a summary of results by writing "copy of results requested" on the back of the return envelope, and printing your name and address below it. Please do not put this information on the questionnaire itself.

I would be most happy to answer any questions you might have. Please write or call. The telephone number is (503) 464-4019.

Thank you for your assistance.

Sincerely,

Judy S. Davis

Project Director 
March 2, 1989

Last week you should have received a questionnaire to help plan transportation for suburban, small town, and nural residents. Your household was selected in a random sample of recent home purchasers near Portland, Oregon.

If you have already completed and returned the questionnaire, please accept our sincere thanks. If not, please do 80 today. Because it was sent to only a small but representative sample of households, it is extremely important that your answers be included in the study.

If by some chance you did not zeceive the questionnaire, or it got misplaced, please call me collect right now (503-464-4019), and I will get another one in the mail to you today.

Sincerely,

Judy S. Davis

Project Director 
March 16,1989

NAME

ADDRESS

CITY, Oregon ZIP

Dear NAME:

About three weeks ago I wrote to you seeking information to help plan transportation for suburban, small town, and rural residents. As of today, I have not yet received your completed questionnaire.

The Center for Urban Studies is investigating why people are moving to areas around cities and how these moves affect travel to work because this information is needed to help plan effective and efficient transportation systems.

I am writing to you again because every questionnaire is important for the validity of the study. Your household was selected in a scientific sampling process. In order for the results of the study to be truly representative of ali recent home purchasers in the region, it is essential that each household in the sample complete and return its questionnaire.

In case your questionnaire has been misplaced, another has been enclosed. I hope to hear from you soon.

Your cooperation is greatly appreciated.

sincerely yours,

Judy S. Davis

Froject Director 
April 20, 1989

NAME

ADDRESS

CITY, Oregon ZIP

Dear NAME:

I am writing to you about our study to help plan transportation for suburban, small town, and rural areas. We have not yet received your completed questionnaire.

The large number of questionnaires which have been returned is very encouraging. But, an accurate assessment of recent movers' experiences depends on you and the others who have not yet responded. Other studies suggest that those of you who have not yet sent in your questionnaires may have had quite different experiences than those who have already responded.

The results of this study are important to people planning transportation systems because of our emphasis on the changes in where people live and the effects of these moves on travel to work. The results will be most useful if they accurately describe the changes taking place.

It is for these reasons, that I am writing to you again. In case our other correspondence did not reach your household, I have enclosed a replacement questionnaire. I hope you will complete and return it in the envelope provided as soon as possible.

I would be happy to send you a copy of the results if you want one. simply put your name, address, and "copy of results requested" on the back of the return envelope.

Your contribution to the success of this study will be greatly appreciated.

Most sincerely,

Judy S. Davis

Project Director 
APPENDIX B

TREATMENT OF MISSING DATA 
TREATMENT OF MISSING DĀTA

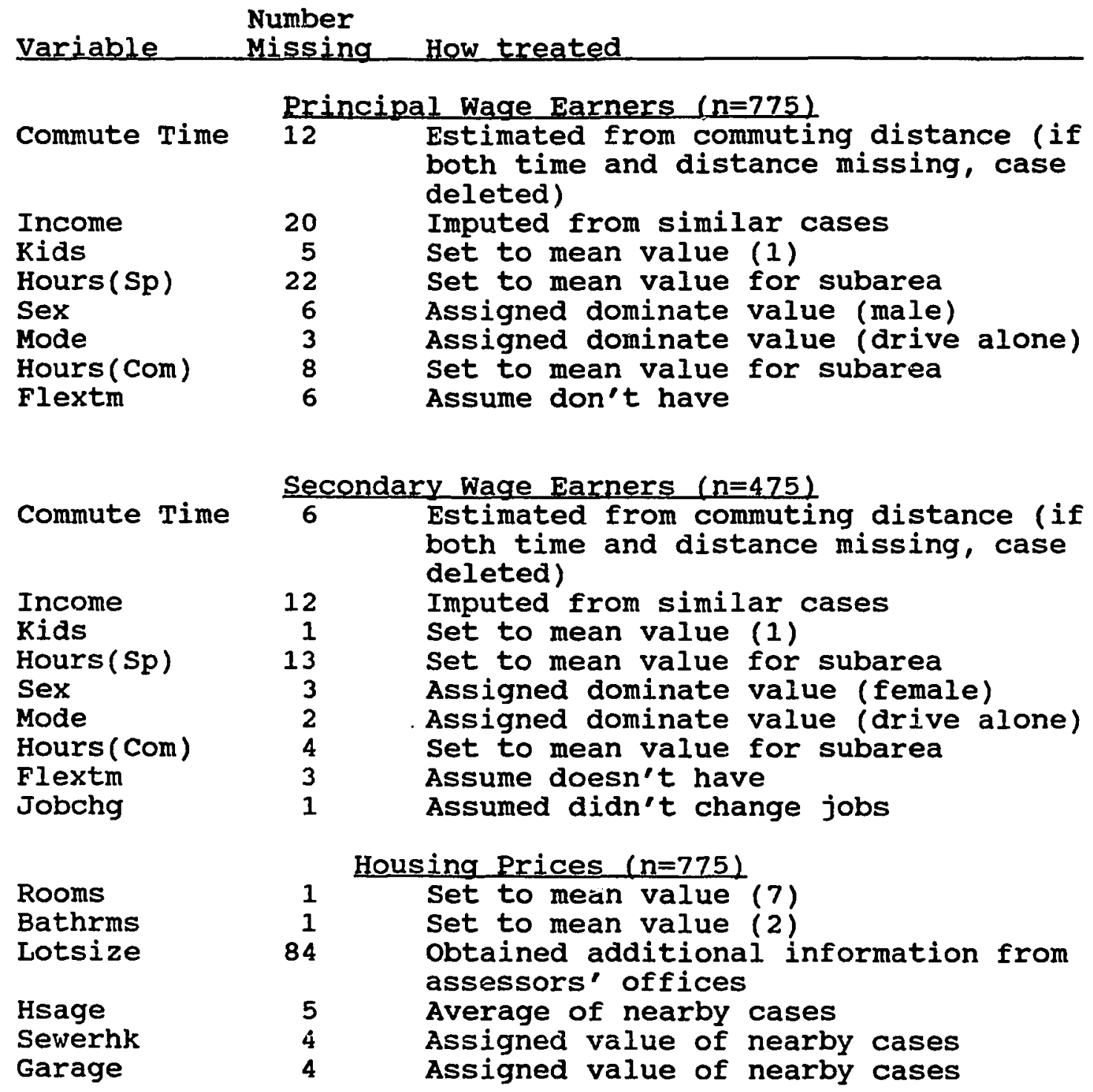


APPENDIX C

SUMMARY STATISTICS FOR REGRESSION 
VARIABLES FOR ESTIMATION OF COMMUTING TIME

Commute Time

minimum

maximum

mean

st. dev.

\section{Principal Wage Earners \\ Exurb Suburb \\ $n=217$}

$\begin{array}{rr}2.0 & 2.0 \\ 80.0 & 50.0 \\ 29.7 & 20.6 \\ 14.8 & 10.2\end{array}$

DCBD

minimum

maximum

mean

st. dev.

Income

minimum

maximum

mean

st. dev.

Kids

minimum

maximum

mean

st. dev.

Adults

minimum

maximum

mean

st. dev.

Hours (Com)

minimum

maximum

mean

st. dev.

Hours ( $S p$ )

minimum

maximum

mean

st. dev.

Whome

minimum

maximum

mean

st. dev.
9.4

36.1

21.5

5.6

1.0

10.0

4.3

2.1

3.3

23.5

10.6

3.2

1.0

10.0

4.6

2.2

0.0

5.0

0.0

1.2

1.2

9.0

1.1

1.2

1.0

5.0

2.1

0.5

1.0

5.0

2.0

0.5

20.0

80.0

44.4

7.6

8.0

90.0

44.7

8.5

0.0

70.0

23.0

18.8

0.0

80.0

20.6

19.8

$\begin{array}{rr}0.0 & 0.0 \\ 20.0 & 25.0 \\ 1.5 & 1.6 \\ 4.0 & 4.0\end{array}$

Secondary Wage Earners

Exurb Suburb

$152 \quad 243$

$\begin{array}{rr}2.0 & 1.0 \\ 105.0 & 65.0 \\ 27.7 & 20.2 \\ 16.0 & 11.3\end{array}$

11.1

3.3

$36.1 \quad 23.5$

$21.0 \quad 10.6$

$5.5 \quad 3.3$

$1.0 \quad 1.0$

$10.0 \quad 10.0$

$4.5 \quad 5.1$

1.92 .1

$0.0 \quad 0.0$

$5.0 \quad 6.0$

1.21 .1

$1.1 \quad 1.1$

$2.0 \quad 2.0$

$4.0 \quad 4.0$

$2.1 \quad 2.1$

$0.3 \quad 0.4$

$4.0 \quad 4.0$

$70.0 \quad 80.0$

$34.0 \quad 36.2$

$12.2 \quad 11.8$

$0.0 \quad 0.0$

$72.0 \quad 80.0$

$42.8 \quad 44.5$

$10.8 \quad 8.6$

$\begin{array}{rr}0.0 & 0.0 \\ 29.0 & 25.0 \\ 1.2 & 1.4 \\ 4.1 & 3.5\end{array}$


VARIABLES FOR ESTIMATION OF COMMUTING TIME

\begin{tabular}{|c|c|c|c|c|}
\hline Job Characteri & $\begin{array}{l}\text { xurb } \\
\text { cs }\end{array}$ & Suburb & Exurb & Suburb \\
\hline flextm & $22 \%$ & $23 \%$ & $21 \%$ & $17 \%$ \\
\hline job chg & 178 & $12 \%$ & $27 \%$ & $22 \%$ \\
\hline MAN\&PROF & $42 \%$ & $48 \%$ & $31 \%$ & $37 \%$ \\
\hline TS\&C & $18 \%$ & $31 \%$ & $45 \%$ & $49 \%$ \\
\hline SERVICE & & & $10 \%$ & $7 \%$ \\
\hline HISKILBLU & $18 \%$ & $8 \%$ & & \\
\hline LOWSKILBLU & 178 & $7 \%$ & & \\
\hline other\&unkn & $6 \%$ & $6 \%$ & $14 \%$ & $7 \%$ \\
\hline \multicolumn{5}{|c|}{ Personal characteristics } \\
\hline $\begin{array}{c}\text { sex(male) } \\
\text { Trip character }\end{array}$ & $\begin{array}{l}88 \% \\
i \mathrm{Cs}\end{array}$ & $82 \%$ & $12 q$ & $15 \%$ \\
\hline mode & $92 \%$ & $88 \%$ & 938 & $89 \%$ \\
\hline
\end{tabular}




\section{Price}

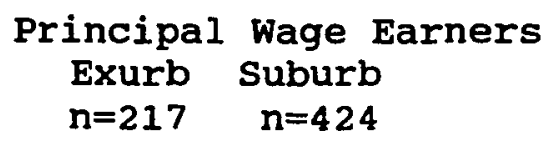

minimum

maximum mean

st. dev.

Rooms

minimum

maximum

mean

st. dev.

Baths

minimum

maximum

mean

st. dev.

Lotsize

minimum

maximum

mean

Hsage

st. dev.

minimum

maximum

mean

st. dev.

Taxrate

minimum

maximum

mean

st. dev.

Schlexp

minimum

maximum

mean

st. dev.

$$
\begin{array}{rr}
10.6 & 15.0 \\
300.0 & 425.0 \\
78.2 & 81.9 \\
35.7 & 40.6
\end{array}
$$

$\begin{array}{rr}3.0 & 3.0 \\ 13.0 & 16.0 \\ 7.3 & 7.2 \\ 2.1 & 2.0\end{array}$

$0.0 \quad 1.0$

$4.0 \quad 4.0$

$1.9 \quad 2.1$

$0.8 \quad 0.7$

$3.5 \quad 0.0$

$1760.0 \quad 440.0$

$226.1 \quad 14.1$

$300.8 \quad 30.6$

$$
\begin{array}{rr}
1.0 & 1.0 \\
100.0 & 99.0 \\
21.6 & 14.6 \\
19.6 & 15.1
\end{array}
$$

$4.3 \quad 10.1$

$31.2 \quad 32.8$

$20.5 \quad 23.4$

$5.0 \quad 2.5$

$2745.7 \quad 3305.8$

$4140.6 \quad 4140.6$

$3616.3 \quad 3833.1$

$304.9 \quad 158.1$

House characterisitcs

$\begin{array}{lrr}\text { condo } & 0 \% & 5 \% \\ \text { mobilehm } & 8 \% & 1 \% \\ \text { waterhk } & 27 \% & 98 \% \\ \text { sewerhk } & 6 \% & 94 \% \\ \text { garage } & 79 \% & 95 \% \\ \text { agforlu } & 16 \% & 0 \%\end{array}$


APPENDIX D

ESTIMATING THE EFFECTS OF PROPERTY TAXES AND

SCHOOL EXPENDITURES ON HOUSING VALUES 


\section{ESTIMATING THE EFFECTS OF PROPERTY TAXES AND SCHOOL EXPENDITURES ON HOUSING VALUES}

Based on the classic article by-Oates (1969) the following calculations were made.

1. Because the coefficients of TAXR are -0.619 in exurbia and -2.708 in suburbia, a $\$ 1$ increase in property $\operatorname{tax}$ rates decreases the value of an exurban home by $\$ 619$ and a suburban home by $\$ 2708$.

2. This $\$ 1$ increase in property tax rates will increase taxes on the average $\$ 80,000$ house by $\$ 80$.

3. If all of the $\$ 80$ is spend on increased support for public schools and if each household has exactly one child attending public schools (and if taxes on non-residential property are ignored), per pupil expenditures will rise by $\$ 80$.

4. Because the coefficients of SCHLEXP are 0.014 in exurbia and 0.016 in suburbia, the $\$ 80$ per pupil expenditure will increase the value of exurban homes by $\$ 1120$ (80x14) and suburban homes by $\$ 1280(80 \times 16)$.

5. Thus the value of exurban homes will increase by $\$ 501$ (1120-619) and the value of suburban homes will decrease by $\$ 1428(1280-2708)$ if tax rates are increased by $\$ 1$ with all funds dedicated to increased spending for public schools. 